\title{
Essays on insider trading
}

Citation for published version (APA):

Keusch, T. (2014). Essays on insider trading. [Doctoral Thesis, Maastricht University]. Datawyse / Universitaire Pers Maastricht. https://doi.org/10.26481/dis.20140626tk

Document status and date:

Published: 01/01/2014

DOI:

10.26481/dis.20140626tk

Document Version:

Publisher's PDF, also known as Version of record

\section{Please check the document version of this publication:}

- A submitted manuscript is the version of the article upon submission and before peer-review. There can be important differences between the submitted version and the official published version of record.

People interested in the research are advised to contact the author for the final version of the publication, or visit the DOI to the publisher's website.

- The final author version and the galley proof are versions of the publication after peer review.

- The final published version features the final layout of the paper including the volume, issue and page numbers.

Link to publication

\footnotetext{
General rights rights.

- You may freely distribute the URL identifying the publication in the public portal. please follow below link for the End User Agreement:

www.umlib.nl/taverne-license

Take down policy

If you believe that this document breaches copyright please contact us at:

repository@maastrichtuniversity.nl

providing details and we will investigate your claim.
}

Copyright and moral rights for the publications made accessible in the public portal are retained by the authors and/or other copyright owners and it is a condition of accessing publications that users recognise and abide by the legal requirements associated with these

- Users may download and print one copy of any publication from the public portal for the purpose of private study or research.

- You may not further distribute the material or use it for any profit-making activity or commercial gain

If the publication is distributed under the terms of Article $25 \mathrm{fa}$ of the Dutch Copyright Act, indicated by the "Taverne" license above, 


\section{ESSAYS ON INSIDER TRADING}


(C) 2014 Thomas Keusch

Production: Datawyse / Universitaire Pers Maastricht

ISBN 9789461593450 


\title{
ESSAYS ON INSIDER TRADING
}

\author{
DISSERTATION \\ to obtain the degree of Doctor \\ at Maastricht University, \\ on the authority of the Rector Magnificus, Prof. Dr. L.L.G. Soete \\ in accordance with the decision of the Board of Deans, \\ to be defended in public \\ on Thursday June 26, 2014, at 10.00 hours \\ by
}

Thomas Keusch

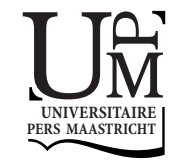




\section{Supervisor}

Prof. Dr. Frank Moers

\section{Assessment Committee}

Prof. Dr. Ann Vanstraelen (Chairperson)

Prof. Dr. Peter C. Schotman

Prof. Dr. Christopher D. Ittner, University of Pennsylvania, United States 

After four and a half years and a couple thousand ols regressions, the dissertation is finally ready. While the process that led to the completion of this dissertation was not always smooth, it was very instructive and despite - or because of - all the hard work, it was also entertaining. There are several people to whom I am extremely grateful for helping to make these past years as productive and enjoyable as they were.

First and foremost, I am indebted to my parents, sister, and family. Over the past years, it seemed like you were oftentimes wondering what I was actually doing at "work". Unfortunately, I never had a clear, satisfying answer. Sometimes, you interpreted me quickly changing the subject of conversation as me believing that it was useless to try to explain to you what I was doing because you wouldn't understand it anyway. Obviously, that was far from the truth: I couldn't explain in a meaningful way what I was doing because - at times - I didn't know myself what I was doing. Fortunately, that changed over time. Despite being left in the dark, you always supported me in all my decisions, and most importantly, you gave me the upbringing, education, motivation, and resilience that I benefit from every single day. I will always be deeply grateful for that.

Next, I would like to thank the person who convinced me to pursue a $\mathrm{PhD}$ in the first place. Who knows what would have happened to me had we not been sitting on Henning's couch in Maastricht that evening, you enthusiastically laying out all the benefits of enrolling in the $\mathrm{PhD}$ program while Henning was preparing wraps. Simone, I am still unsure as to whether you actually thought that me pursuing an academic career was a good idea or whether you just wanted to find some way to keep me in Maastricht for another couple of years. Now that I think about it, both motivations are fine with me. Either way, I am very happy that I followed your advice and I am thankful for your friendship and I hope that it will last.

On my way to my first meeting with my potential future supervisor, Professor Dr. Moers, I was expecting an old guy with gray hair and a beard. As it turned out, Frank was and looked quite the opposite (even though his recent Facebook pictures suggest that the beard has become popular). Frank, I benefitted immensely from the inspiring, hands-off, but critical way with which you guided me in my research efforts. You taught me economic reasoning, which worked quite well until the day I started fantasizing about investor sentiment. Soon thereafter you sent me off to Duke and before I could come back to Maastricht, you organized another visit for me at Penn. Clearly, I benefitted enormously from your network. Unfortunately, I wasn't always as grateful as I should have been, for example during our basketball match. I apologize for that and I promise to do "better" if we ever meet on the court again.

Soon after starting the $\mathrm{PhD}$ program, I met the two guys with whom I would share an office, conference hotel rooms, and many lasting memories over the ensuing years. Patrick and Jonas, you were the best office mates that I could have hoped for. The way we have beaten up each other on our research ideas - sometimes constructive, sometimes destructive certainly made me a better researcher. Equally important, all the jokes, nights out, and vacation that we enjoyed together ensured that I had a lot of fun during the $\mathrm{PhD}$ program inside and outside the office. I would like to thank you for that and I hope that there are many more such activities to come.

Fortunately, Jonas, Patrick and I were not alone in the program. Nadine, I am glad you proved to have the thick skin that was necessary to survive and prosper in a group of guys like 
us. Fortunately, I will not miss you or the "motto parties" that you threw for us because I will soon welcome you as a colleague in Rotterdam. Christoph, you just fitted right in. Fortunately for you, you did not have to share an office with Jonas, Patrick, and me. Fortunately for us, we still got you out of your comfort zone quite a bit. Isabell and Ronny, it was unfortunate that you left the department so early. The experiences up to that date suggested that there was a lot of potential to be exploited. I hope we can do that in Madrid soon. Thank you Reka for all the fun, great Hungarian food, and endless discussions about disclosure of any kind.

There are many others whom I would like to thank for the great time I had in Maastricht: Sissi and Franz for joining, hosting, and adding to numerous social activities, Sacha, Tanja, Sabine, Marjo, Juliette, and Miranda who made my life so much easier, Alex for his subtle constructive criticism of my outward appearance and use of language, Felix for leaving academia when threatened to become my daily supervisor and returning upon my graduation, all the other colleagues in the Accounting department who made it a great place to work, Norbert, the Diris Brothers, Mona, Britt, Judith, Lars, Bass, Tyas, Bart, Ehsan, Matteo, Paulo, the Wharton Accounting PhD students, my friends from Übach, my new colleagues in Rotterdam, and especially Eva.

I also want to express my gratitude to the people that I have worked with over the past years, each of whom I have learned a lot from. In order of appearance: Harold, Laury, Katrin, Shane, Bill, Thomas, Alon, Wei, Lucian, and Chris. In addition, I am indebted to Cedric, Shane, and Wayne for inviting me to spend time at Copenhagen Business School, Duke, and Penn, respectively.

Lastly, I would like to thank my dissertation committee: Ann, thanks for your support throughout the program and for taking the chairwomanship. Peter, thank you for joining my committee and for all your comments. Chris, thanks for your support at Wharton and for travelling to my defense from Philly. 


\section{TABLE OF CONTENTS}

Introduction

1.1. Legal background on insider trading in the United States ...................................................... 7

1.2. Overview about insider trading activity in the United States................................................. 8

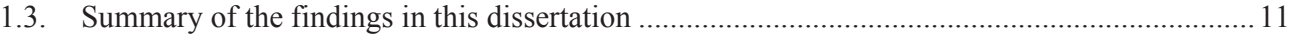

Insider Trading on Superior Information: Evidence from a Natural Experiment.................................. 15

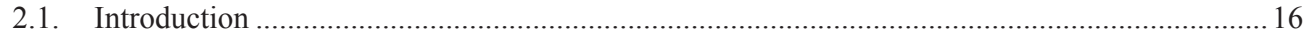

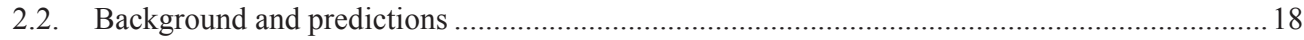

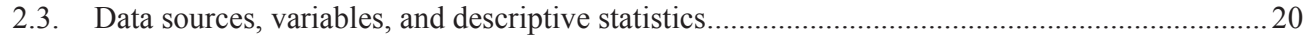

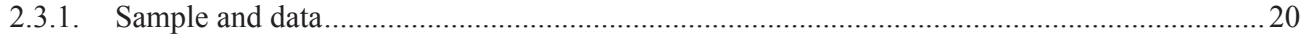

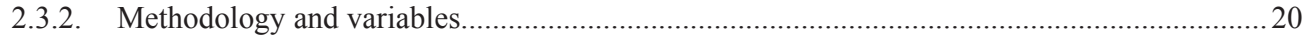

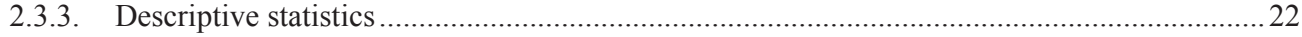

2.4. Information asymmetry in the patent application process ................................................. 22

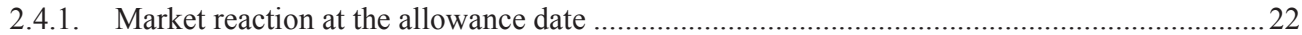

2.4.2. Market reaction to mandatory patent application publication prior to the grant date ..............23

2.4.3. Market reaction to patent grant conditional on mandatory patent application ..........................26

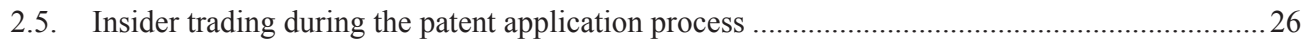

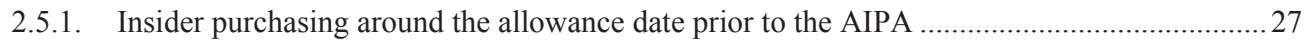

2.5.2. Insider purchasing in the month after the allowance date compared to insider purchasing in the

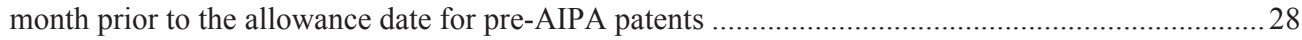

2.5.3. Insider purchasing in the month after the allowance date compared to insider purchasing in the month prior to the allowance date for post-AIPA patents .................................................................... 30

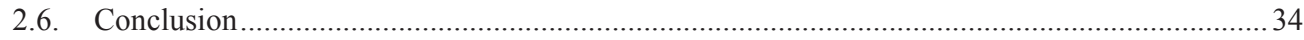

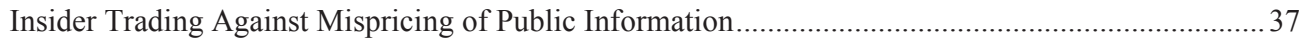

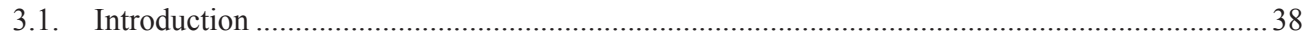

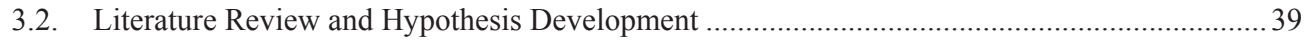

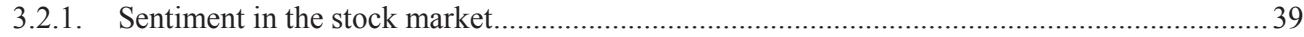

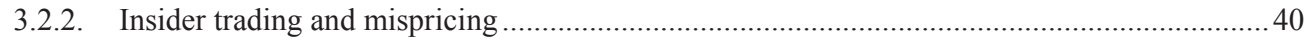

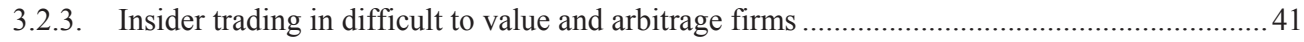

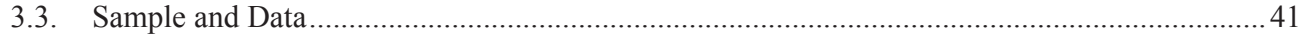

3.3.1. Sample selection and variables for analyses of insider trading patterns and profits ................42

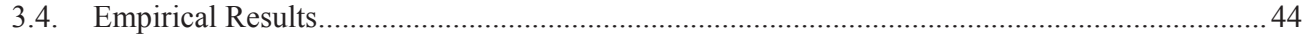

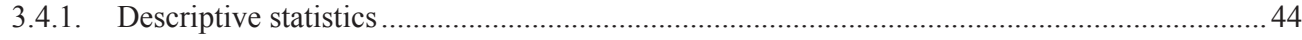

3.4.2. Market level relation between mispricing and aggregate insider trading................................. 44

3.4.3. Firm level relation between mispricing and insider trading ..................................................... 46

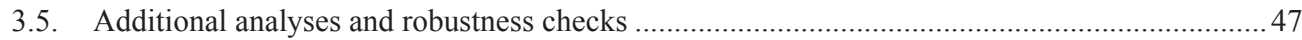




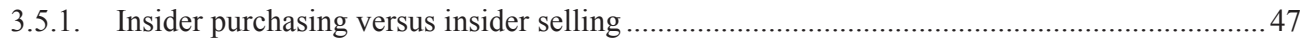

3.5.2. Different difficult to value and arbitrage proxies..................................................................... 49

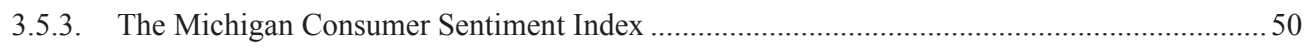

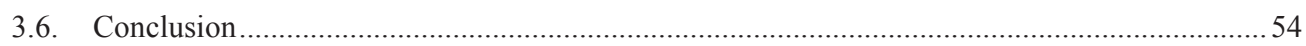

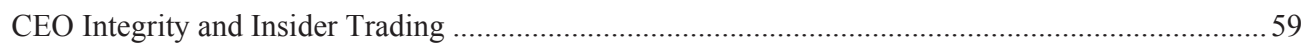

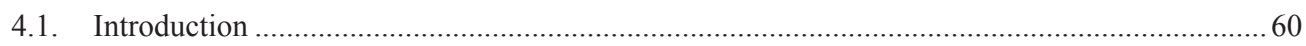

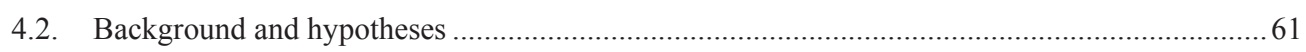

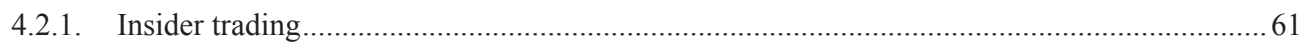

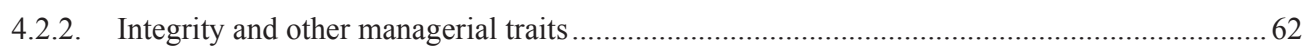

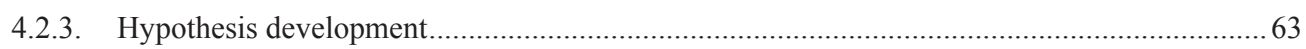

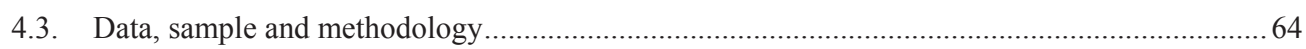

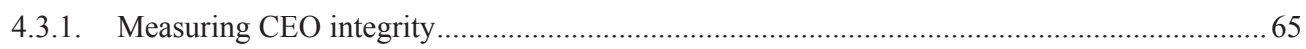

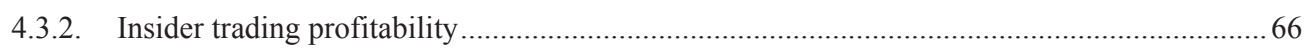

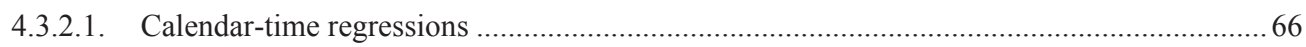

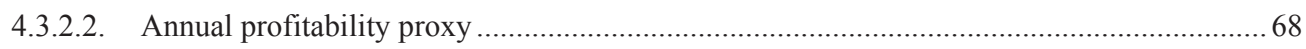

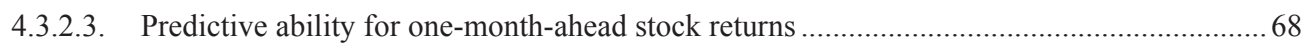

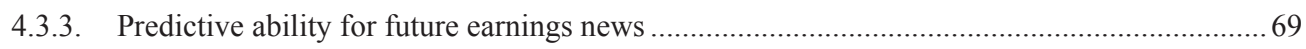

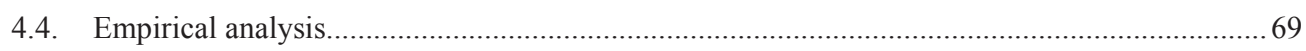

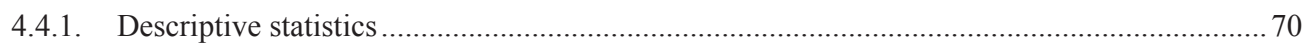

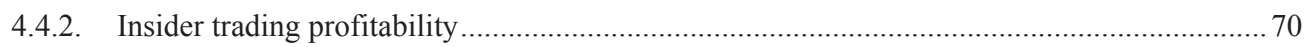

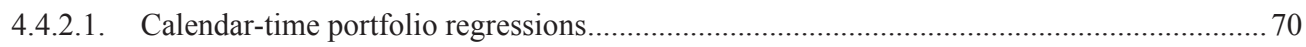

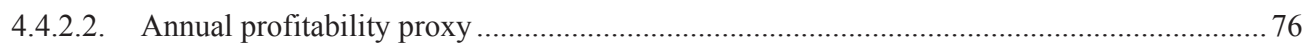

4.4.2.3. Predictive ability for one month ahead stock returns........................................................... 76

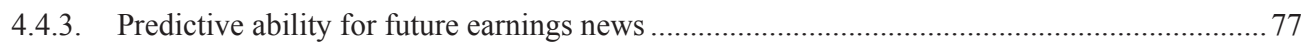

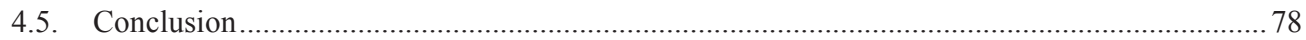

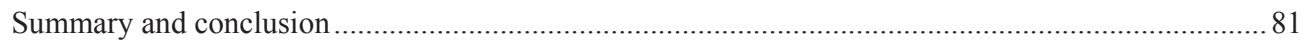





\section{Introduction}

Insider trading in financial markets is a topic of recurring interest in academia and practice. Academics have long debated whether the benefits of insider trading, namely increased market efficiency and reduced contracting cots between shareholders and managers, outweigh the costs borne by less-informed capital markets participants who unknowingly find themselves at the other end of insider transactions.

Practitioners are interested in insider trading for at least two reasons. First, financial markets regulators, such as the Securities and Exchange Commission (SEC), seek to identify illegal insider transactions, that is, those transactions that are based on non-public material information. Prominent SEC insider trading investigation targets include Jeffrey Skilling, former CEO of Enron, who was convicted in May 2006; Raj Rajaratnam, founder of the Galleon Group, convicted in October 2011; and Rajat Gupta, former CEO of McKinsey \& Co., convicted in October 2012.

Second, other capital markets participants who do not have access to private information try to infer and trade on information that is revealed in insider transaction disclosures. Separate sections in business papers as well as entire websites are dedicated to the tracking and analysis of disclosed insider transactions. ${ }^{1}$ Some websites provide investment guidance based on the intensity of insider trading in particular stocks or the market as a whole.

The empirical studies in this dissertation examine some of the information - private and public - that corporate insiders trade on as well as the relation between insiders' personal traits and their trading profitability. The results of these studies help to understand insiders' trading strategies as well as the insider characteristics that influence the propensity to trade on private information and the profitability of insider transactions.

\subsection{Legal background on insider trading in the United States}

Before jumping to the empirical part of this dissertation, however, I provide some background information and stylized facts about insider trading in the United States. I focus on insider trading laws and insider trading behavior in the US because the empirical studies carried out in this dissertation are all conducted using US data.

Rule 10b-5 of the Securities Exchange Act of 1934 prohibits the purchase or sale of a security of any issuer, on the basis of material nonpublic information about that security or issuer. Since corporate insiders are those market participants who are most likely to hold material nonpublic information about their companies, their personal transactions are subject to specific disclosure requirements. According to Section 16 of the Securities Exchange Act of 1934, corporate insiders include beneficial owners of more than ten percent of a firm's equity securities, corporate directors, and corporate officers. Before Section 403 of the Sarbanes-Oxley Act (SOX) came into effect on August 29, 2002 the trades conducted by these corporate insiders in their firms' shares had to be disclosed to the SEC on Form 4 by the tenth day of the calendar month following the month of the transaction. The SEC would then make the Form 4 filing publicly available in due course. As of August 29, 2002, Form 4 has to

\footnotetext{
${ }^{1}$ For example see http://www.insidermonkey.com/insider-trading/ and http://wsj.com/mdc/public/page/2_3023-insider.html
} 
be filed with the SEC within two business days and since June 30, 2003, it has to be electronically filed through the Electronic Data Gathering, Analysis, and Retrieval system (EDGAR) on the SEC's website, which makes the information instantly available to the public. These publicly disclosed Form 4 filings are then tracked by investors, newspapers, and commercial data providers. ${ }^{2}$

The disclosure requirements described above might have some disciplining effect on corporate insiders' propensity to trade on private information. Even if corporate insiders did not trade on private information, they could still generate abnormal trading profits, however, if they are able to identify mispricing of publicly available information.

Next to the transactions of corporate insiders, there are of course other forms of insider trading. Consultants, investment banks, auditors, hedge funds, or other market participants that are not subject to the above disclosure requirements might have access to material nonpublic information about companies' prospects and use this information for their own transactions. These transactions are very difficult to observe, however, and are, hence, not subject of the studies in this dissertation.

\subsection{Overview about insider trading activity in the United States}

Insider trading by corporate officers and directors has increased in magnitude with the widespread use of equity compensation in the 1990s as documented in Figure 1.1A for insider purchases and in Figure 1.1B for insider sales. These two figures plot the monthly aggregate dollar value of insider purchases and sales by corporate officers and directors in the US against the level of the Standard \& Poor's 500 index between January 1986 and December 2011. Figure 1.1A shows that purchasing activity increased substantially in the months following the stock market crash on 'Black Monday' in October 1987 (cf. Seyhun, 1990). In addition, Figures 1.1A and 1.1B show that there was substantial insider buying and insider selling during the build-up of the dotcom bubble in 1998 and 1999 followed by record levels of insider selling at the peak of the market in 2000 and 2001. Insider purchasing activity peaked in May 2008, right before a prolonged and severe decline in the S\&P 500 that lasted until February 2009. Another spike in aggregate insider purchasing in August 2011 was followed by a substantial drop in the S\&P 500 in September 2011. The evidence in Figures $1.1 \mathrm{~A}$ and $1.1 \mathrm{~B}$ is somewhat mixed regarding the question whether insiders, on aggregate, are able to time the market. Until the end of the dotcom bubble, it seems like insiders purchased shares after significant market drops and during upswings while selling near the peak of the market. During the latest financial crisis, however, insiders, on aggregate, might not have done particularly well at predicting market movements, especially with their purchases.

Examining whether aggregate insider trading predicts future movements of the overall stock market is not suitable for the measurement of insider trading profitability, however. Aggregate insider transactions will only predict the market if insiders have better information about future changes in macro-economic fundamentals or are able to observe market-wide mispricing.

\footnotetext{
${ }^{2}$ I do not rule out the possibility that some market participants, such as the market maker, are able to identify insider transactions before they are publicly disclosed by the SEC.
} 
Figure 1.1A

\section{Monthly Value of Insider Purchases 1986-2011}

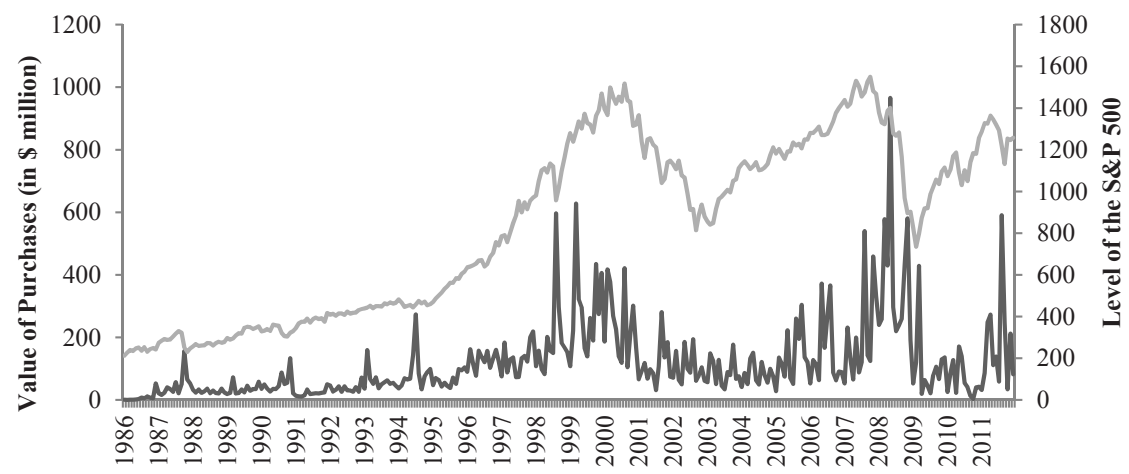

- Insider Purchases $\longrightarrow$ S\&P 500

Figure 1.1B

Monthly Value of Insider Sales 1986-2011

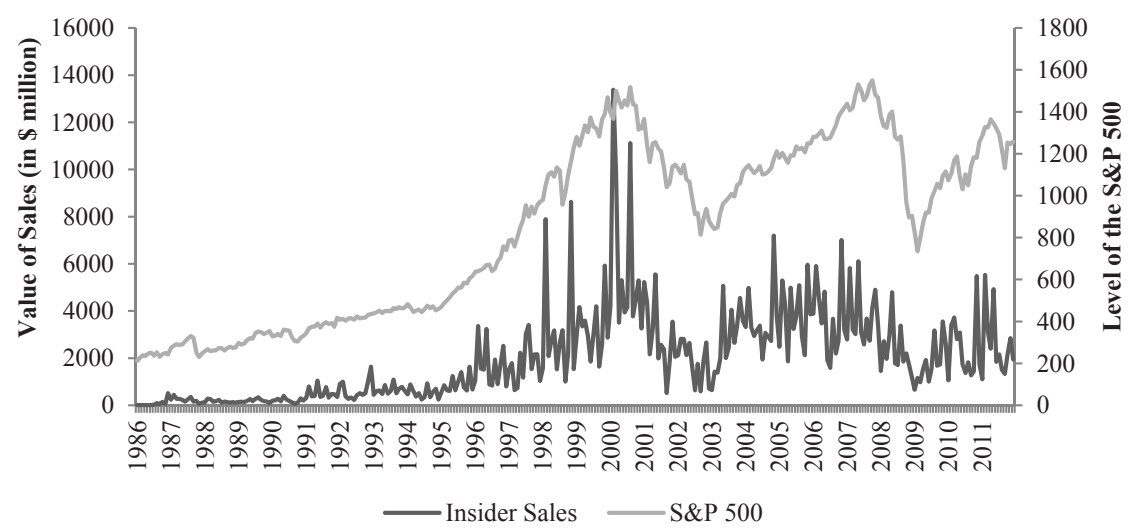

However, if all private information and mispricing is firm-specific, then insiders' transactions in each firm will cancel out and aggregate insider trading will be unrelated to subsequent returns on the S\&P 500 index or other market indices. ${ }^{3}$ The estimation of insider trading profitability is further complicated by data limitations. Since insider sales cannot be reliably matched to earlier insider purchases, it is virtually impossible to estimate exact holding periods. Given these limitations, one way to estimate insider trading profitability is to examine whether insider purchases and insider sales predict future cumulative abnormal stock returns (CAR).

Figure 1.2 shows the cumulative abnormal (i.e. market-adjusted) stock returns over the 100 days leading up to insider transactions ( $t-100$ through $t-1$ ) and over the 100 days

${ }^{3}$ (Seyhun, 1992) finds that between 1975 and 1989 aggregate insider trading activity did predict future returns on the stock market. 
subsequent to insider transactions $(t+1$ through $t+100) .{ }^{4}$ Figure 1.2 documents that the shares that insiders purchase have on average experienced abnormal returns of about $-6 \%$ over the 100 days leading up to the transaction. More importantly, over the 100 days subsequent to insider purchases, those shares outperform the market by almost $8 \%$ on average. Prior to insider sales, the shares sold by insiders outperform the market by about $12 \%$ on average. Subsequent to the transactions, the shares sold by corporate insiders move with the market. Two conclusions can be drawn from Figure 1.2. First, insider purchases predict future returns while insider sales do not, suggesting that purchases are more profitable than sales. The likely reason is that insiders only purchase shares if they believe that their firm is undervalued given their information set. In contrast, insiders might sell shares for reasons unrelated to information, for example after new compensation-related equity grants, in order to diversify their portfolio. Second, insiders appear to trade contrarian, that is, they sell when past performance was high and purchase when past performance was low.

Figure 1.2

Stock Price Performance Around Insider Transactions

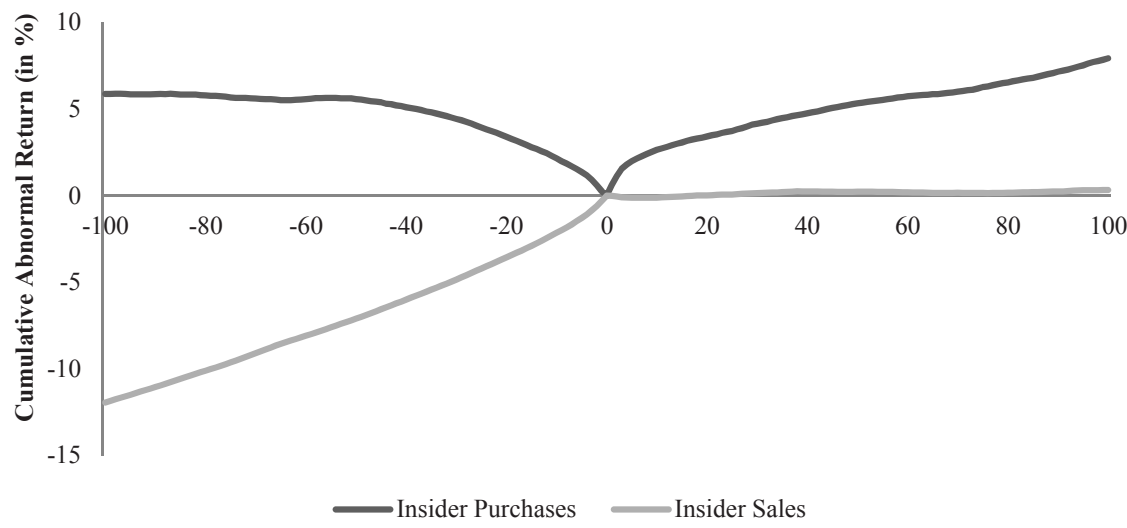

As described earlier, external market participants supposedly take cues from insider trading disclosure, assuming that insider transactions provide valuable information regarding the value of the firm. If external market participants mimic disclosed insider transactions, there should be an observable price reaction around the date of the insider trading disclosure. Figure 1.3 documents this price reaction for both, insider purchase disclosures and insider sale disclosures in the 41 days surrounding the disclosure date. ${ }^{5}$ In line with the findings in Figure 1.2 , abnormal returns prior to insider purchase disclosures are slightly negative at between -40 and -20 basis points per day. On and after the disclosure, the abnormal returns are positive and amount to a total of 146 basis points over the first three days, indicating that external market participants revise their beliefs about firm value upwards. For insider sales, there is a much weaker reaction. Prior to the sales disclosure, daily abnormal returns range between 10 and 30

4 The CAR for day - $t$ is the sum of the daily abnormal (i.e. market-adjusted) returns beginning on day -t and ending on day 1. The CAR for day $t$ is the sum of the daily abnormal returns beginning on day 1 and ending on day $t$. This procedure yields a time series of CARs for each insider transaction; these CARs are averaged across all purchases and sales to produce the figure. The sample includes transactions by corporate insiders and officers between July 1, 2003 and December 31, 2011.

${ }^{5}$ The abnormal return on day $t$ is the stock return less the market return on day $t$. This procedure produces a time series of daily abnormal returns for each insider trade disclosure; these daily abnormal returns are averaged across all purchases and sales to produce the figure. The sample includes transactions by corporate insiders and officers between July 1, 2003 and December 31, 2011. 
basis points and after the disclosure they turn indistinguishable from zero. These results suggest that external market participants react to insider purchase disclosures but not insider sales disclosures. The absence of a reaction to insider sales is likely due to the expectation held by external market participants that insider sell shares primarily for liquidity or diversification reasons.

Figure 1.3

Price Reaction to Insider Trading Disclosure

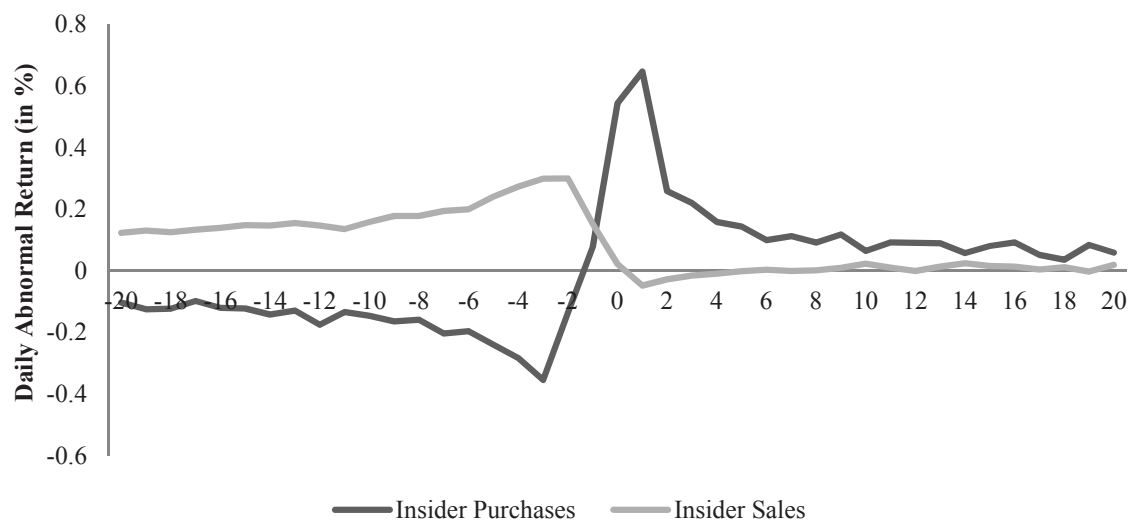

\subsection{Summary of the findings in this dissertation}

The empirical studies in the following chapters of this dissertation build on the findings presented above. The first and second empirical chapters examine the sources of insider trading profits, that is, the nature of nonpublic and public information that insiders trade on. Specifically, the first empirical study considers insiders' foreknowledge of future patent grants as a possible source of insider trading profits. Important for this particular study, we know exactly when information asymmetry between insiders and external market participants arises during the patent application process. The main finding of this study is that insiders trade on their foreknowledge of future patent grants.

The second study considers public information as a source of insiders' trading profits. More specifically, if publicly available information is not efficiently incorporated into share prices and insiders can identify this mispricing, then insiders can profit from trading on this mispricing of publicly available information. I use market-wide investor sentiment waves as a proxy for mispricing of public information and find strong evidence that insiders trade against this mispricing.

The third empirical study examines the relation between the personal characteristics of CEOs and their trading profits. Using a proxy for CEO integrity that is constructed from publicly available data, we show that out-of-integrity CEOs achieve higher trading profits and are more likely to trade on private information about future earnings surprises than inintegrity CEOs.

The results of the three empirical studies in this dissertation contribute to the literature in several ways. First, using a unique research setting which allows us to identify the exact date on which information asymmetry between insiders and outsiders arises, we document that insiders exploit private information that they acquire during the patent application process. 
This result contributes to the discussion about whether corporate insiders trade on material nonpublic information (Givoly and Palmon, 1985; Ke et al., 2003; Piotroski and Roulstone, 2005). The second study contributes to the ongoing debate about whether insiders are able to identify and trade against mispricing of publicly available information (Rozeff and Zaman, 1998; Piotroski and Roulstone, 2005; Jiang and Zaman, 2010) by documenting that insiders trade against mispricing that is related to sentiment waves. By relating insider trading behavior to a theory-based proxy of CEO integrity, the third study contributes to the literature on the importance of management characteristics for corporate events, policies, and outcomes (Bertrand and Schoar, 2003) and helps to identify ex-ante which insider transactions are likely to be profitable. 


Insider Trading on Superior Information: Evidence from a Natural Experiment

\begin{abstract}
In this paper, we focus on the patent application process at the United States Patent and Trademark Office (USPTO) to examine whether corporate insiders trade on superior information. The patent application process provides a unique research setting for at least two reasons: First, while prior research examining whether insiders trade on superior information often assumes that insiders are in the possession of private information, we can identify the exact point in time when insiders receive private information regarding the grant decision of pending patent applications from the USPTO. Second, the implementation of the American Inventors Protection Act (AIPA) in 2000 causes exogenous variation in the level of information asymmetry between insiders and outsiders regarding pending patent applications since it mandates publication of pending patent applications within 18 months of the patent application date regardless of whether a grant decision is already reached and communicated. Using detailed hand-collected data on high-impact patents granted to US companies, we find that insider purchasing activity increases significantly following the private communication between the USPTO and the firm but only if the private communication was not preceded by mandatory publication of the pending patent application.
\end{abstract}

This chapter is based on a working paper that is coauthored with Katrin Hussinger and Frank Moers. 


\subsection{Introduction}

While prior research consistently shows that insider trades generate abnormal returns (e.g. Lorie and Niederhoffer, 1968; Jaffe, 1974; Jeng et al., 2003) there is mixed evidence regarding the question whether these abnormal returns are due to insider trading on superior information. For example Elliott et al. (1984) and Givoly and Palmon (1985) find little evidence that insiders' trading profits are driven by insider trading shortly before corporate news announcements. Similarly, Agrawal and Jaffe (1995) show that insider trading regulation discourages insiders from trading shortly before merger announcements. In contrast to the aforementioned studies, the results in Seyhun and Bradley (1997), Ke et al. (2003), Piotroski and Roulstone (2005), and Veenman (2012) suggest that insiders do trade on foreknowledge of corporate events.

The mixed results in prior research might reflect the ambiguity of the assumptions that the researcher has to make regarding (a) whether corporate insiders possess private information prior to material corporate events and (b) at what point in time insiders acquire this private information. For example, Ke et al. (2003) assume that insiders can predict future breaks in strings of consecutive earnings increases up to nine quarters before the breaks actually occur.

The patent application process in the United States provides a powerful setting to examine insider trading on superior information since it is known at which point in time information asymmetry between insiders and outsiders with respect to future patent grants arises: As soon as the USPTO decides that it will grant a patent, it privately sends a notice of allowance to the applicant which details the USPTO's decision including the scope of the patent grant. ${ }^{6}$ Patent applications filed before November 2000 were not publicly disclosed until the patent grant date, which means that outsiders only learned at the grant date that a patent application existed and that patent protection was awarded. Thus, insiders enjoyed a significant information advantage over outsiders until the American Inventors Protection Act (AIPA) of 1999, which determined that most patents applied for on or after November $29^{\text {th }} 2000$ must be disclosed by the USPTO within 18 months after the patent application date (USPTO, 1999). ${ }^{7}$ Thus, if the USPTO sends the notice of allowance after the mandatory publication of the patent application, information asymmetry between insiders and outsiders is reduced under the new regulation because outsiders can use the published patent application to assess the patent grant probability and the claimed patent scope.

In this paper, we predict and find that corporate insiders use their foreknowledge of high impact patent grants for their personal trading decisions and that this strategic insider trading behavior is mitigated by the exogenous mandatory publication of the patent application under the AIPA. ${ }^{8}$ Specifically, our empirical results show that insider purchasing activity increases significantly during the month following the private receipt of the notice of allowance for patents filed before the AIPA came into force. Exploiting exogenous variation in the level of information asymmetry between insiders and outsiders after the implementation of the AIPA,

\footnotetext{
${ }^{6}$ In the US, one patent can ask protection for several patent claims. Patent claims describe the invention in technical terms defining the legal boundaries of patent protection. The number and nature of claims constitutes the scope of the patent.

${ }^{7}$ The mandatory publication applies for patent applications that seek international protection: On filing of a patent application on or after November 29, 2000, an applicant may request that the application not be published, but only if the invention has not been and will not be the subject of an application filed in a foreign country that requires publication 18 months after filing at the latest.

American Inventors Protection Act of 1999; Public Law 106-113, 113 Stat. 1501

${ }^{8} \mathrm{We}$ focus on high-impact patents because patents have been shown to have an extremely skewed value distribution (Harhoff et al., 1999; Jaffe et al., 2005). We classify patents as high impact based on the number of forward citations a patent receives.
} 
we further show that insider purchasing activity in the post-allowance month is lower for those patents whose application documents were published by the USPTO before the firm privately received the notice of allowance. Corroborating the assumption that mandatory publication of patent applications conveys information to outsiders, we document a significant stock market reaction at the date of mandatory patent application publication. In addition, we show that the market reaction around the grant date of high-impact patents is significantly lower if the patent application was previously disclosed by the USPTO.

We make contributions to at least three distinct literature streams. First, we contribute to the discussion on the sources of insiders' trading profits (Aboody and Lev, 2000; Ke et al., 2003; Bartov and Mohanram, 2004; Ahuja et al., 2005; Piotroski and Roulstone, 2005; Cheng et al., 2007; Huddart et al., 2007; Cohen et al., 2012; Veenman, 2012) by documenting that insiders exploit information asymmetries that are generated by the nature of the patent application process. In that respect, this paper is most closely related to studies by Ahuja et al. (2005) and Aboody and Lev (2000). Ahuja et al. find that insiders purchase more shares in the years that precede patent applications. Hence, Ahuja et al. make the assumption that insiders know that the firm will apply for a patent, whether the patent will be granted, what the scope of the legal protection will be and how the patent grant will influence share price performance. Our study is different in that we take advantage of the powerful research setting that the USPTO patent application process provides, which reveals the exact point in time when information asymmetry between insiders and outsiders is greatest. We complement the results presented in Aboody and Lev (2000) who show that insider trading profits are greater in R\&D intensive firms. We shed light on the trading strategies and the timing of the trades through which insiders in R\&D intensive firms generate the abnormal trading profits reported in Aboody and Lev.

Our findings are also related to the literature that examines whether compensation-based incentives motivate managers to invest in innovation (Lerner and Wulf, 2007; Francis et al., 2011; Manso, 2011; Ederer and Manso, 2012). While these studies establish a link between ex-ante equity incentives and innovation output, we document a relation between innovation output and insiders' subsequent equity portfolio decisions. This link is important because if insiders were not able to trade on their knowledge of future patent grants, their equity incentives would trigger less innovation efforts in the first place (cf. Bebchuk and Fershtman, 1994). Thus, we complement these studies by providing insights into the trading strategies that permit insiders to personally benefit from $R \& D$ activities that generate patentable inventions.

Finally, we contribute to a discussion on the uncertainties and information asymmetries created by the US patent application process. While most patent applications will be granted in some form, there is substantial uncertainty regarding the nature and number of claims that will be granted (USPTO, 2011). Gans et al. (2008) show that this uncertainty delays the licensing of patent rights by start-up innovators until the patent allowance is communicated to the applicant who can then credibly demonstrate the value of the patent to potential licensees. Thus, while they find that the patent allowance decreases information asymmetry between the start-up patent applicant and the incumbent licensee, we show that insiders in publicly listed firms use the increased information asymmetry between themselves and external market participants for insider trading. 
In this regard, the results reported in this paper also point to a potentially beneficial side effect of the AIPA (USPTO, 1999). The act was intended to decrease information asymmetries between applicants and related parties, and, hence, stimulate faster knowledge dispersion (cf. Johnson and Popp, 2003). The results imply that one consequence of the AIPA is that it limits corporate insiders in their ability to trade on private information regarding future patent grants.

We proceed as follows: Section 2 provides an overview over the patent application process and reviews the relevant literature. Section 3 describes the sample, data, and relevant variables. Section 4 provides empirical evidence on the information asymmetry that is created during the patent application process. Section 5 examines whether insiders exploit this information asymmetry and Section 6 concludes.

\subsection{Background and predictions}

In this section we give an overview of the patent application process at the USPTO and elaborate on how the structure of the process might influence insider trading strategies in patenting firms. Figure 2.1 provides a timeline illustrating the sequence of events during the US patent application process for patent applications filed (i) before the implementation of the American Inventors Protection Act (AIPA) (Panel A), (ii) patent applications filed after the AIPA that were published before the allowance date (Panel B), and (iii) patent applications filed after the AIPA that were published after the allowance date (Panel C). ${ }^{9}$

The patent application process commences when an individual or corporation files an application with the USPTO. The application contains a detailed description of the invention, all prior art, and the number and nature of the claims for which the applicant seeks protection. Although about $90 \%$ of patents applied for in the US eventually get granted in some form, there is significant uncertainty about the number and the breadth of claims that will be granted. Only very few patents are granted as filed (USPTO, 2011). Once the patent examiner has decided that the patent will be granted and which claims will receive protection, the USPTO sends a notice of allowance to the applicant. In the following, we refer to the day on which the USPTO sends the notice of allowance as the allowance day. Although the notice of allowance is not the official grant, this private communication from the USPTO to the applicant significantly reduces the applicant's uncertainty about the claims that will receive protection (Gans et al., 2008).

If the patent application is not published prior to the allowance date (see Panels A and C of Figure 2.1), insiders of the applying firm enjoy a significant informational advantage over outside market participants, which they can use for their personal trading decisions: For patents applied for before the AIPA came into force, the information asymmetry is only resolved at the official patent grant date when the market learns about the pending patent application and the claims that were granted (see Figure 2.1 Panel A).

\footnotetext{
${ }^{9}$ Although the USPTO is supposed to publish pending patent publications that were filed after the American Inventors Protection Act within 18 months of the filing date, we find (as Figure 2.1 Panel C suggests) that only about $90 \%$ of all pregrant patent publications occur within this time frame.
} 
Figure 2.1

Panel A: Pre-AIPA $(n=3,857)$

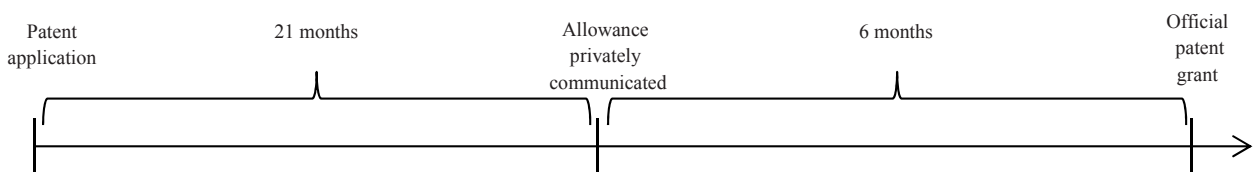

Panel B: Post-AIPA, patent publication before the allowance date $(\mathrm{n}=1,074)$

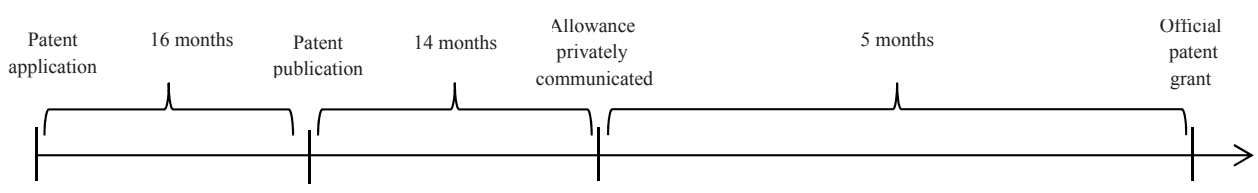

Panel C: Post-AIPA, patent publication after the allowance date $(\mathrm{n}=321)$

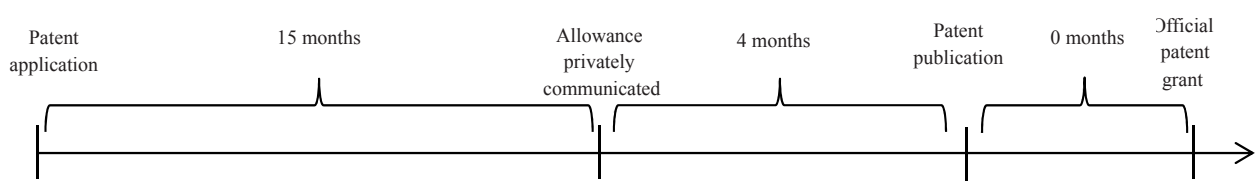

This figure provides a timeline illustrating the sequence of events during the US patent application process for patents applied for (i) before the implementation of the American Inventors Protection Act (AIPA), (ii) patents applied for after the AIPA that were published before the allowance date, and (iii) patent applied for after the AIPA that were published after the allowance date. The time intervals specified are based on the median patent in the sample.

For patent applications filed after the AIPA, information asymmetry between insiders and outside market participants is resolved either at the grant date or on the date that the USPTO publishes the pending patent application (see Figure 2.1 Panel C). ${ }^{10}$

If the patent application is published prior to the allowance date (see Figure 2.1 Panel B), the market can use the published patent application material to assess the probability that the pending patent application will eventually be granted and estimate which claims will receive protection. Hence, at the allowance date, insiders have less of an informational advantage visà-vis outside market participants than had the patent application not been published prior to the allowance date.

If insiders are able to judge the economic value of pending patent applications, perceive stock markets to be less than strong-form efficient, and estimate the legal jeopardy associated with SEC investigations into insider trading as sufficiently low (Huddart et al., 2007), they have an incentive to trade on their superior information about future patent grants. This incentive is stronger for patents whose applications were not published prior to the allowance

\footnotetext{
${ }^{10} 62 \%$ of the sample patent applications that were filed after the AIPA are not published prior to the official grant date, which is why the median time lag between patent publication and patent grant in Figure 2.1 Panel $\mathrm{C}$ is 0 . There are two possible reasons. First, the time lag between application and grant was short enough and mandatory publication of the patent application was not required. Second, the patent application only requests protection at the USPTO and not at foreign patent offices such as the Japanese Patent Office (JPO) or the European Patent Office (EPO). The data does not allow us to differentiate between these possible reasons.
} 
date, that is, patents that were applied for before November $29^{\text {th }} 2000$, or patents that were applied for after this date but for which the notice of allowance was sent to the firm before mandatory publication of the application material took place. For these patents, information asymmetry after the allowance date is larger compared to patents that were published prior to the allowance date. Thus, we predict that purchasing by corporate insiders increases after the receipt of the patent allowance if the patent application was not published prior to the allowance.

\subsection{Data sources, variables, and descriptive statistics}

\subsubsection{Sample and data}

In this study we use hand-collected data on high impact patents granted by the USPTO to US corporate applicants between 1994 and 2006. We focus only on high impact patents because there is great heterogeneity and skewness in the economic value of patented inventions (Harhoff et al., 1999; Hall et al., 2005; Jaffe et al., 2005). We identify high impact patents based on the number of forward citations that a patent receives. Several studies show the number of forward citations is a suitable indicator of the economic value of patents (Hirschey and Richardson, 2004; Hall et al., 2005; Czarnitzki et al., 2011). Hall et al. (2001) find that in the first five years after the grant date, patents receive up to a third of their life-time forward citations. Hence, in order to reliably identify high impact patents, we require at least five years of citation data subsequent to the patent grant date. In order to obtain five years of forward citation data for patents granted in 2006, we combine the National Bureau of Economic Research (NBER) patent citations database (cf. Hall et al., 2001; Jaffe et al., 2005), which only extends until 2006, with patent citation data from the Patent Statistical Database (PATSTAT, release April 2012), which extends until 2011. Then we classify all patents based on their grant year and technological category ${ }^{11}$ and select the top $1 \%$ patents in terms of forward citations received. After dropping patents which cannot be assigned to a permanent unique firm identifier (PERMNO) or for which insider trading data in ThomsonReuters is not available, we are left with 5,252 firm-patent combinations, that is, 5,237 unique patents granted to 526 firms between 1994 and 2006. ${ }^{1213} 1,395$ of these patents were applied for after the AIPA came into force. 1,074 of the latter are published prior to the allowance date, 321 are not. For each high-impact patent we hand-collect the allowance date from the Patent Application Information Retrieval (PAIR) system on the USPTO website and we collect accounting data and stock prices for the applying firms from Compustat and CRSP, respectively. ${ }^{14}$ Because we want to discard as little information as possible, the number of patents used for the different analyses varies with the availability of non-missing data on the variables that are relevant to the particular analysis.

\subsubsection{Methodology and variables}

Since we argue that the patent application process creates information asymmetries at the allowance day that can be exploited by insiders, our empirical strategy is to (a) provide

\footnotetext{
${ }^{11}$ The six main technological categories are Computers and Communications, Drugs and Medical, Electrical and Electronics, Chemical, Mechanical and Others (Hall et al., 2001).

${ }^{12}$ We clean the ThomsonReuters insider trading data along the lines of Jeng et al. (2003).

${ }^{13}$ One patent application can be filed by and granted to more than one firm.

${ }^{14}$ The PAIR system can be accessed via http://portal.uspto.gov/external/portal/pair/
} 
evidence for the existence of information asymmetry, (b) compare insider purchasing activity up to three months right after the allowance date to insider purchasing up to three months before the allowance date, and (c) examine whether increases in insider purchasing activity in the month after the allowance date is conditional on whether the patent application is published prior to the allowance date.

Regarding (a) we test for stock market reactions (i) at the allowance date, (ii) around the mandatory publication of patent applications, and (iii) at the patent grant date. Since prior research suggests that prices during the dotcom bubble period were not entirely informationdriven (e.g. Abreu and Brunnermeier, 2003; Ofek and Richardson, 2003; Brunnermeier and Nagel, 2004), we test for stock market reactions on samples including and excluding patents that received the allowance between 1999 and 2001. With respect to patent grants, we test whether the market reaction at the grant date is conditional on whether patent applications were disclosed prior to the grant date. We measure the stock market reaction as the buy-andhold abnormal (market-adjusted) stock return over either a three-day window centered on the publication, allowance, or grant date (Allowance 3-day BHAR; Publication 3-day BHAR; Grant 3-day BHAR) or a seven day window starting the day before the publication/allowance/grant date (Allowance 7-day BHAR; Publication 7-day BHAR; Grant 7-day BHAR).

Regarding (b) we focus on patents that were applied for before the AIPA came into force and test whether insider purchasing activity after the allowance date is higher than insider purchasing activity before the allowance date. In (c) we focus on patents that were applied for after the AIPA was implemented to examine whether the increase in insider purchasing activity after the allowance date is conditional on mandatory publication of patent applications.

We measure insider purchasing activity in two ways. First, we use an indicator variable that is equal to one if there is at least one open-market insider purchase in a given firm-month and equal to zero otherwise (IndBuy). Second, we use the natural logarithm of one plus the dollar value of open-market purchases in a given firm-month as the dependent variable ( $\operatorname{Ln}($ ValueBuy)). In (b) the main independent variables of interest are either indicator variables for the months surrounding the allowance date $\left(\right.$ Month $_{t-f} ; M^{\prime}$ Monh $\left._{t+f}\right)$ or an indicator variable that is equal to one in the month after the allowance date and equal to zero in the month before the allowance date (Post Allowance). In (c) the variables of interest are 'Post Allowance', an indicator variable that is equal to one if patent application occurred before the allowance date and equal to zero otherwise (Publication Before Allowance) and the interaction between these two variables.

Prior literature provides guidance regarding suitable control variables. First, we control for firm market capitalization ( $\operatorname{Ln}($ Market Cap)). Prior studies show that managers in large firms receive more equity-based compensation (Core and Guay, 1999). Thus, managers in large firms might be more inclined to sell shares and less likely to buy additional shares for portfolio diversification reasons. On the other hand, if firm size proxies for insiders' outside wealth, one might expect more insider purchasing in larger firms. Next, we control for a firm's growth opportunities with the book-to-market ratio (B/M). Prior research shows that insiders are more likely to buy (sell) when the book-to-market ratio is high (low), possibly because the book-to-market ratio is an indicator for under- or overvaluation (Rozeff and Zaman, 1998; Piotroski and Roulstone, 2005). Since Huddart and Ke (2007) show that insider 
trading volume is increasing in R\&D intensity and decreasing in analyst following, we also control for R\&D expenditures scaled by sales (RND/Sales) and the natural logarithm of one plus the number of analysts covering the firm (Ln(Analysts)). We also control for continuously-compounded buy-and-hold stock returns over the past six months (Past Returns). Insiders are more likely to purchase when past returns are low, possibly because they interpret stock price decreases as signals for undervaluation (Piotroski and Roulstone, 2005). Since Roulstone (2003) shows that some firms have corporate policies that restrict insider trading to the month after the quarterly earnings announcement date, 'Safe' is equal to one if a given firm-month overlaps with the first month after a quarterly earnings announcement. 'Post SOX' is equal to one in the period after the implementation of the Sarbanes-Oxley Act.

Since the treatment period (the month right after the allowance date) and the control period (the month right before the allowance date) often occur in the same fiscal year, we measure the control variables on a monthly basis whenever possible. We also control for application year fixed effects as well as allowance year fixed effects and industry fixed effects. In order to mitigate concerns that our results are driven by correlated omitted timeinvariant firm characteristics, we also use specifications with firm fixed effects. Since we use interaction terms as well as firm fixed effects in some of the model specifications we estimate all models with Ordinary Least Squares (OLS) rather than logit, probit, or tobit. ${ }^{15}$

\subsubsection{Descriptive statistics}

Panel A of Table 2.1 shows patent characteristics, while Panel B presents descriptive statistics for two firm-months per patent, the firm-month leading up to the patent allowance and the firm-month immediately after the patent allowance.

Panel A of Table 2.1 shows that for the 5,252 firm-patent combinations in our sample, the median patent collects about 113 forward citations and receives protection for 27 claims. The median high impact patent takes 645 days or about 22 months to receive an allowance and the median time lag between application and grant date is 824 days (about 27 months). Around $20 \%$ of the sample patents are published before the corporate applicant receives the patent allowance notification.

Panel B reveals that insider purchasing in the two months surrounding the allowance date is on average $11 \%$. The median sample firm has a book-to-market ratio of about 0.27 indicating that the sample firms have significant growth options in form of their R\&D and patenting activities. For the median firm, R\&D expenditures make up roughly $8 \%$ of total sales. In line with prior research (Barth et al., 2001), analyst following is high in our sample of R\&D intensive firms with median analyst coverage of 20 estimates.

\subsection{Information asymmetry in the patent application process}

\subsubsection{Market reaction at the allowance date}

Our prediction that information asymmetry between insiders and outsiders increases at the date when the USPTO communicates the patent allowance to the firm hinges on the assumption that the allowance does not leak into the stock market. We test the validity of this

\footnotetext{
${ }^{15}$ Greene (2010) argues that one should not conduct hypotheses testing on interaction terms in nonlinear models such as logit, probit, or tobit.
} 
assumption with an event study for the date when the allowance is sent to the firm. If the information in the patent allowance leaks into the market, we expect a positive market reaction around the allowance date and this reaction should be stronger if the patent application was not published due to the AIPA prior to the patent allowance. If on the other hand, the patent allowance is kept secret, we do not expect to observe any significant market reaction around the allowance date. We calculate the market reaction for two event windows. The first window has a length of three days and is centered on the allowance date (Allowance 3-day BHAR). The second window takes into account that it might take the market some time to evaluate allowance and, hence, lasts from the day before the allowance to five days after the allowance (Allowance 7-day BHAR). Table 2.2 shows the results of this event study. In line with the intuition that the patent allowance increases information asymmetry between the insiders of the applying firm and outside market participants, we do not observe a significant market reaction around the date of the patent allowance.

Even for those patents for which the patent application is not disclosed prior to the allowance date there is no market reaction at the allowance date. This result supports the notion that the USPTO privately communicates the patent allowance to the applicant and that the applicant has little incentive to disclose the patent allowance because doing so would lead to imitation by the competition.

\subsubsection{Market reaction to mandatory patent application publication prior to the grant date}

Our prediction that insider purchasing activity after the allowance date is higher than before the allowance date if patent applications were not previously published hinges on the assumption that mandatory publication of patent applications provides significant information to the market. In this section, we test whether the stock market reacts to the mandatory publication of patent applications. Specifically, we perform an event study to test whether the buy-and-hold abnormal stock return for firms for which a patent application is published is significantly different from zero. Similar to the prior section, we calculate the market reaction for two event windows. The first window has a length of three days and is centered on the patent publication date (Publication 3-day BHAR) and the second lasts from the day before the publication to five days after the publication (Publication 7-day BHAR). 
Table 2.1. Summary Statistics of Main Variables

\begin{tabular}{|c|c|c|c|c|c|}
\hline & Mean & SD & 25 & Median & 75 \\
\hline \multicolumn{6}{|l|}{ Panel A: Patent level descriptives } \\
\hline Forward Citations & 137.5356 & 87.5389 & 79.0000 & 113.0000 & 171.5000 \\
\hline Claims & 26.7656 & 19.9360 & 14.0000 & 22.0000 & 34.0000 \\
\hline Allowance Lag & 718.0861 & 386.1743 & 442.0000 & 645.0000 & 918.0000 \\
\hline Grant Lag & 894.6026 & 391.4044 & 615.0000 & 824.0000 & 1103.0000 \\
\hline Post AIPA & 0.2656 & 0.4417 & 0.0000 & 0.0000 & 1.0000 \\
\hline Publication Before Allowance & 0.2045 & 0.4034 & 0.0000 & 0.0000 & 0.0000 \\
\hline Allowance 3-day BHAR & 0.0008 & 0.0516 & -0.0209 & -0.0001 & 0.0222 \\
\hline Allowance 7-day BHAR & 0.0011 & 0.0781 & -0.0351 & -0.0002 & 0.0353 \\
\hline Publication 3-day BHAR & 0.0012 & 0.0514 & -0.0199 & 0.0005 & 0.0220 \\
\hline Publication 7-day BHAR & 0.0049 & 0.0749 & -0.0322 & -0.0008 & 0.0347 \\
\hline Grant 3-day BHAR & 0.0023 & 0.0537 & -0.0204 & 0.0006 & 0.0232 \\
\hline Grant 7-day BHAR & 0.0024 & 0.0785 & -0.0330 & 0.0002 & 0.0354 \\
\hline \multicolumn{6}{|c|}{ Panel A: Firm-month level descriptives } \\
\hline IndBuy & 0.1104 & 0.3134 & 0.0000 & 0.0000 & 0.0000 \\
\hline ValueBuy & 70585.6961 & 932608.4145 & 0.0000 & 0.0000 & 0.0000 \\
\hline Market Cap & $4.5852 \mathrm{e}+10$ & $7.8566 \mathrm{e}+10$ & $2.9499 \mathrm{e}+09$ & $1.3631 \mathrm{e}+10$ & $4.7054 \mathrm{e}+10$ \\
\hline $\mathrm{B} / \mathrm{M}$ & 0.3253 & 0.2761 & 0.1707 & 0.2667 & 0.4315 \\
\hline RND/Sales & 0.1797 & 1.4558 & 0.0492 & 0.0752 & 0.1449 \\
\hline Past Returns & 0.1021 & 0.4117 & -0.1204 & 0.0620 & 0.2615 \\
\hline Analysts & 19.8173 & 10.2936 & 12.0000 & 20.0000 & 27.0000 \\
\hline Safe & 0.6382 & 0.4805 & 0.0000 & 1.0000 & 1.0000 \\
\hline Post SOX & 0.3201 & 0.4665 & 0.0000 & 0.0000 & 1.0000 \\
\hline
\end{tabular}

Panel A shows descriptive statistics per high-impact patent. Panel B shows firm characteristics for the month prior to and the month after the allowance date. 'Forward Citations' is the number of forward citations that a patent received. 'Claims' is the number of claims for which a patent received protection. 'Allowance Lag' is the number of days between the patent application date and the patent allowance date. 'Grant Lag' is the number of days between the patent application date and the patent grant date. 'Post AIPA' is an indicator variable equal to 1 if the patent was applied for after the American Inventors Protection Act (AIPA) came into force.

'Publication Before Allowance' is an indicator variable equal to 1 if the patent disclosure preceded the allowance date and 0 otherwise. 'Allowance 3-day BHAR' is the abnormal (market-adjusted) buy-and-hold stock return over a three day window centered on the allowance date. 'Allowance 7-day BHAR' is the abnormal (market-adjusted) buy-and-hold stock return over a seven day window starting the day before the allowance date. 'Publication 3-day BHAR' is the abnormal (market-adjusted) buyand-hold stock return over a three day window centered on the patent publication date. 'Publication 7-day BHAR' is the abnormal (market-adjusted) buy-and-hold stock return over a seven day window starting the day before the patent publication date. 'Grant 3day BHAR' is the abnormal (market-adjusted) buy-and-hold stock return over a three day window centered on the patent grant date. 'Grant 7-day BHAR' is the abnormal (market-adjusted) buy-and-hold stock return over a seven day window starting the day before the patent grant date. 'IndBuy' is an indicator variable equal to 1 if there is insider purchasing in a given month and zero otherwise. 'ValueBuy' is the dollar value of insider purchasing in a given month. 'Market Cap' is market capitalization at the beginning of the month. 'B/M' is the book-to-market ratio at the end of the prior fiscal year. 'RND/Sales' is research and development expenses scaled by sales revenue at the end of the prior fiscal year. 'Past Returns' is the buy-and-hold stock return over the six months leading up to the beginning of the month. 'Analysts' is the number of analysts following the firm at the beginning of the month. 'Safe' is equal to one if the month before/after the allowance date overlaps with the first month after a quarterly earnings announcement date. 'Post SOX' is equal to one in the period after the implementation of the Sarbanes-Oxley 


\begin{tabular}{|c|c|c|}
\hline & Allowance 3-day BHAR & Allowance 7-day BHAR \\
\hline \multicolumn{3}{|c|}{ Panel A: All patents } \\
\hline Mean & 0.000828 & 0.001118 \\
\hline SE & 0.0007 & 0.0011 \\
\hline Observations & 5225 & 5225 \\
\hline t-statistic & 1.1593 & 1.0349 \\
\hline \multicolumn{3}{|c|}{ Panel B: Patents that are not published before the allowance } \\
\hline Mean & 0.001095 & 0.001453 \\
\hline SE & 0.0008 & 0.0013 \\
\hline Observations & 4156 & 4156 \\
\hline t-statistic & 1.2954 & 1.1463 \\
\hline \multicolumn{3}{|c|}{ Panel C: All patents excluding dotcom bubble } \\
\hline Mean & 0.000003 & 0.000882 \\
\hline SE & 0.0007 & 0.0011 \\
\hline Observations & 3887 & 3887 \\
\hline t-statistic & 0.3902 & 0.8078 \\
\hline \multicolumn{3}{|c|}{ Panel D: Patents that are not published before the allowance excluding dotcom bubble } \\
\hline Mean & 0.000453 & 0.001252 \\
\hline SE & 0.0009 & 0.0013 \\
\hline Observations & 2822 & 2822 \\
\hline t-statistic & 0.5084 & 0.9454 \\
\hline \multicolumn{3}{|c|}{$\begin{array}{l}\text { One-sample t-tests of the stock market reaction around the day when the USPTO communicates the patent allowance to the } \\
\text { applying firm. In Panel A, the sample consists of all patents. In Panel B, the sample consists of those patents that were not } \\
\text { published before the allowance date. In Panel C the sample consists of all patents that did not receive the allowance during the } \\
\text { dotcom bubble period (1999-2001). In Panel B the sample consists of those patents that were not published before the } \\
\text { allowance date and did not receive the allowance during the dotcom bubble period (1999-2001). 'Allowance 3-day BHAR' is } \\
\text { the abnormal (market-adjusted) buy-and-hold stock return over a three day window centered on the allowance date. } \\
\text { 'Allowance 7-day BHAR' is the abnormal (market-adjusted) buy-and-hold stock return over a seven day window starting the } \\
\text { day before the allowance date. }\end{array}$} \\
\hline
\end{tabular}

Table 2.3. Market Reaction to Patent Publication before Grant Date

\begin{tabular}{|c|c|c|}
\hline & Publication 3-day BHAR & Publication 7-day BHAR \\
\hline \multicolumn{3}{|c|}{ Panel A: All patents that are published before the grant date } \\
\hline Mean & 0.0011989 & 0.0048883 \\
\hline SE & 0.0015118 & 0.0022054 \\
\hline Observations & 1154 & 1154 \\
\hline t-statistic & 0.793 & 2.2165 \\
\hline \multicolumn{3}{|c|}{ Panel B: Patents that are published before the grant date excluding dotcom bubble } \\
\hline Mean & 0.001185 & 0.004874 \\
\hline SE & 0.0015 & 0.0022 \\
\hline Observations & 1149 & 1149 \\
\hline t-statistic & 0.7805 & 2.2068 \\
\hline \multicolumn{3}{|c|}{$\begin{array}{l}\text { One-sample t-tests of stock market reaction to the publication of patent applications prior to the patent grant date. In Panel A, } \\
\text { the sample consists of all patents that were published before the grant date. In Panel B, the sample consists of the patents that } \\
\text { were published before the grant date and did not receive the allowance during the dotcom bubble period (1999-2001). } \\
\text { 'Publication 3-day BHAR' is the abnormal (market-adjusted) buy-and-hold stock return over a three day window centered on } \\
\text { the patent publication date. 'Publication 7-day BHAR' is the abnormal (market-adjusted) buy-and-hold stock return over a } \\
\text { seven day window starting the day before the patent publication date. }\end{array}$} \\
\hline
\end{tabular}

Table 2.3 shows the results of the two one-sample t-tests. Across both samples, the threeday buy-and-hold abnormal return is about twelve basis points, which is not statistically significant. However, the seven-day abnormal return is about half a percentage point in both 
samples with t-values in excess of 2.2. These results provide some modest evidence that mandatory pre-grant publication of pending high-impact patent applications provides valuable information to the market regarding future patent grants. Importantly, the results support the proposition that mandatory publication of patent applications reduces information asymmetry between insiders and outsiders, limiting insiders' ability to derive personal gains from their foreknowledge of future patent grants.

\subsubsection{Market reaction to patent grant conditional on mandatory patent application}

In this section we supplement the previous results by examining whether the market reaction at the patent grant date is lower for those patents that were disclosed prior to the grant date. First, we perform two-sample t-tests of the market reaction at the patent grant date conditional on mandatory pre-grant publication of the patent publication. Then we perform regression analysis with the market reaction as the dependent variable and an indicator for patent publication prior to the grant date (Publication Before Grant) as the independent variable of interest.

Panels A and B of Table 2.4 show the results of the two-sample t-tests. When those patents that receive the allowance during the dotcom bubble period are included in the sample (Panel A), we do not find that patent application disclosure prior to the grant date has an influence on the market reaction at the grant date. However, for the sample excluding the dotcom period patents (Panel B), the market reaction at the grant date is significantly higher if the patent application was not published prior to the grant date. Panel C of Table 2.4 confirms the latter results in multiple regressions. Specifically, the results from the regression analyses imply that patent publication prior to the grant date decreases the abnormal buy-and-hold return around the grant date by 25 to 38 basis points. These results supplement those reported in Table 2.3 and imply that mandatory publication of patent applications - due to the AIPA conveys important information regarding future patent grants to the market and, hence, significantly reduce information asymmetry between insiders and outsiders. Consequently, more information about potential future patent grants is incorporated into the share price when patent applications are published due to the AIPA, which reduces insiders' incentive to trade after the receipt of the patent allowance if mandatory publication precedes the allowance. We test this conjecture in the next section.

\subsection{Insider trading during the patent application process}

In this section we test whether insider purchasing activity after the allowance date is higher than insider purchasing activity before the allowance date and whether this effect is attenuated by mandatory publication of patent applications due to the AIPA. 
Table 2.4. Market Reaction to Patent Grant Conditional on Patent Publication

\begin{tabular}{|c|c|c|c|c|}
\hline \multicolumn{5}{|c|}{ Panel A: Two-sample t-tests (all patents) } \\
\hline & \multicolumn{2}{|c|}{ Grant 3-day BHAR } & \multicolumn{2}{|c|}{ Grant 7-day BHAR } \\
\hline & $\begin{array}{c}\text { No Publication } \\
\text { Before Grant }\end{array}$ & $\begin{array}{c}\text { Publication Before } \\
\text { Grant }\end{array}$ & $\begin{array}{l}\text { No Publication } \\
\text { Before Grant }\end{array}$ & $\begin{array}{c}\text { Publication Before } \\
\text { Grant }\end{array}$ \\
\hline Mean & 0.0025065 & 0.0016841 & 0.0027573 & 0.0011929 \\
\hline SE & 0.0009104 & 0.0010701 & 0.0013288 & 0.001588 \\
\hline Observations & 4025 & 1186 & 4025 & 1186 \\
\hline t-statistic & & & & \\
\hline \multicolumn{5}{|c|}{ Panel B: Two-sample t-tests (excluding dotcom bubble) } \\
\hline & \multicolumn{2}{|c|}{ Grant 3-day BHAR } & \multicolumn{2}{|c|}{ Grant 7-day BHAR } \\
\hline & $\begin{array}{c}\text { No Publication } \\
\text { Before Grant }\end{array}$ & $\begin{array}{c}\text { Publication Before } \\
\text { Grant }\end{array}$ & $\begin{array}{c}\text { No Publication } \\
\text { Before Grant }\end{array}$ & $\begin{array}{c}\text { Publication Before } \\
\text { Grant }\end{array}$ \\
\hline Mean & 0.004155 & 0.001681 & 0.004993 & 0.001162 \\
\hline SE & 0.0009 & 0.0011 & 0.0014 & 0.0016 \\
\hline Observations & 2712 & 1181 & 2712 & 1181 \\
\hline t-statistic & & & & \\
\hline \multicolumn{5}{|c|}{ Panel C: Regression analysis (excluding dotcom bubble) } \\
\hline & (1) & (2) & (3) & (4) \\
\hline & \multicolumn{2}{|c|}{ Grant 3-day BHAR } & \multicolumn{2}{|c|}{ Grant 7-day BHAR } \\
\hline Publication Before Grant & $\begin{array}{l}-0.0025^{*} \\
(-1.73)\end{array}$ & $\begin{array}{c}-0.0027^{*} \\
(-1.78)\end{array}$ & $\begin{array}{c}-0.0038^{*} \\
(-1.66)\end{array}$ & $\begin{array}{l}-0.0032 \\
(-1.41)\end{array}$ \\
\hline Ln(Grant Lag) & & $\begin{array}{c}0.0002 \\
(0.16)\end{array}$ & & $\begin{array}{l}0.0007 \\
(0.33)\end{array}$ \\
\hline Ln(Market Cap) & & $\begin{array}{l}-0.0007 \\
(-1.32)\end{array}$ & & $\begin{array}{c}-0.0022 * * * \\
(-2.77)\end{array}$ \\
\hline $\mathrm{B} / \mathrm{M}$ & & $\begin{array}{l}0.0051 \\
(1.08)\end{array}$ & & $\begin{array}{l}-0.0057 \\
(-0.73)\end{array}$ \\
\hline Constant & $\begin{array}{c}0.0042 * * * \\
(4.07)\end{array}$ & $\begin{array}{c}0.0124 \\
(1.10)\end{array}$ & $\begin{array}{l}0.0050 * * * \\
(3.51)\end{array}$ & $\begin{array}{c}0.0373 * * \\
(2.10)\end{array}$ \\
\hline Observations & 3,893 & 3,890 & 3,893 & 3,890 \\
\hline R-squared & 0.001 & 0.003 & 0.001 & 0.005 \\
\hline
\end{tabular}

Two-sample t-test and OLS regression model of the stock market reaction at the patent grant date conditional on patent publication prior to the grant date. In the regression analysis (Panel C), standard errors clustered by firm, t-statistics are in parentheses and $* * *, * *$, and $*$ denote statistical significance at the $0.01,0.05$, and 0.1 level, respectively (two-tailed). The sample in Panel A consists of all patents. The sample in Panels B and C excludes patents that received the allowance in the dotcom bubble period (1999-2001). 'Grant 3-day BHAR' is the abnormal (market-adjusted) buy-and-hold stock return over a three day window centered on the patent grant date. 'Grant 7-day BHAR' is the abnormal (market-adjusted) buy-and-hold stock return over a seven day window starting the day before the patent grant date. 'Publication Before Grant' is an indicator variable equal to 1 if the patent was disclosed before the grant date and 0 otherwise. 'Ln(Grant Lag)' is the natural logarithm of the number of days between the application date and the grant date. 'Ln(Market Cap)' is the market capitalization at the end of the prior month. ' $\mathrm{B} / \mathrm{M}$ ' is the book-to-market ratio at the end of the prior fiscal year.

\subsubsection{Insider purchasing around the allowance date prior to the AIPA}

First, we provide an overview over insider purchasing activity in the months surrounding the allowance dates for patents that were applied for prior to the implementation of the AIPA. None of the patents in this sample was disclosed prior to the allowance date. The aim is to investigate whether insider purchasing increases in the months following the allowance date relative to the months before the allowance date. Hence, we construct a panel of twelve months per patent, six months before the allowance date and six months after the allowance date and estimate the following models for firm $\mathrm{i}$, patent $\mathrm{j}$, and month $\mathrm{t}$. 
IndBuy $_{\mathrm{i}, \mathrm{j}, \mathrm{t}}=\alpha+\beta_{1}$ Month $_{\mathrm{i}, \mathrm{j}, \mathrm{t}-3}+\beta_{2}$ Month $_{\mathrm{i}, \mathrm{j}, \mathrm{t}-2}+\beta_{3}$ Month $_{\mathrm{i}, \mathrm{j}, \mathrm{t}-1}+\beta_{4}$ Month $_{\mathrm{i}, \mathrm{j}, \mathrm{t}+1}+$

$\beta_{5}$ Month $_{\mathrm{i}, \mathrm{j}, \mathrm{t}+2}+\beta_{6}$ Month $_{\mathrm{i}, \mathrm{j}, \mathrm{t}+3}+\gamma \mathrm{X}+\varepsilon_{\mathrm{i}, \mathrm{j}, \mathrm{t}}$

$\operatorname{Ln}(\text { ValueBuy })_{\mathrm{i}, \mathrm{j}, \mathrm{t}}=\alpha+\beta_{1}$ Month $_{\mathrm{i}, \mathrm{j}, \mathrm{t}-3}+\beta_{2}$ Month $_{\mathrm{i}, \mathrm{j}, \mathrm{t}-2}+\beta_{3}$ Month $_{\mathrm{i}, \mathrm{j}, \mathrm{t}-1}+\beta_{4}$ Month $_{\mathrm{i}, \mathrm{j}, \mathrm{t}+1}+$ $\beta_{5}$ Month $_{\mathrm{i}, \mathrm{j}, \mathrm{t}+2}+\beta_{6}$ Month $_{\mathrm{i}, \mathrm{j}, \mathrm{t}+3}+\gamma \mathrm{X}+\varepsilon_{\mathrm{i}, \mathrm{j}, \mathrm{t}}$

where months $\mathrm{t}-6$ through $\mathrm{t}-4$ before the allowance date and months $\mathrm{t}+4$ through $\mathrm{t}+6$ after the allowance date are captured in the intercept as reference group such that the coefficients on the indicator variables Month $_{\mathrm{i}, \mathrm{j}, \mathrm{t}-3}-$ Month $_{\mathrm{i}, \mathrm{j}, \mathrm{t}+3}$ compare insider purchasing activity right around the allowance date to insider purchasing activity in a period that is more distant in time from the allowance date and, hence, presumably unaffected by the allowance date. $\mathrm{X}$ represents a vector of patent and firm level control variables as well as year fixed effects.

The results are presented in Table 2.5. Across all model specification with and without control variables and fixed effects, insider purchasing in the month right after the allowance date is significantly higher than insider purchasing in the control period. This implies that the action, in terms of increased insider purchasing activity, predominately occurs immediately after the allowance date, which leads us to conduct more refined analyses with the first month after the allowance date as the treatment month in the remainder of this section. With respect to the control variables, insider purchasing activity around the allowance date is significantly lower when the time lag between allowance date and application date is long, suggesting that information regarding pending patent applications is less likely to leak into the market when the patent application process is shorter. Consistent with prior research, insider purchasing activity is higher in the month following the quarterly earnings announcement (Roulstone, 2003). In addition, insiders purchase more in larger firms. Insider purchasing is lower when past stock returns are high and is greater when the book-to-market ratio is high (Piotroski and Roulstone, 2005). Finally, insider purchasing is lower when analyst following is high (Huddart and Ke, 2007).

\subsubsection{Insider purchasing in the month after the allowance date compared to insider purchasing in the month prior to the allowance date for pre-AIPA patents}

In this section, we formally compare insider purchasing in the month after the allowance date to insider purchasing in the month prior to the allowance date for the sample of patents that were applied for before the implementation of the AIPA. These two months should, on average, be very similar to each other except for the arrival of the notice of allowance and, hence, increased information asymmetry between insiders and outsiders. The variable 'Post Allowance' in equations (2a) and (2b) presented below is an indicator variable equal to one in the month following the allowance date and equal to zero in the last month prior to the allowance date. 
Hence, the panel underlying equations (2a) and (2b) is comprised of two months per firmpatent combination.

IndBuy $_{\mathrm{i}, \mathrm{j}, \mathrm{t}}=\alpha+\beta_{1}$ Post $_{\text {Allowance }} \mathrm{ij, \textrm {t }}+\gamma \mathrm{X}+\varepsilon_{\mathrm{i}, \mathrm{j}, \mathrm{t}}$

$\operatorname{Ln}(\text { ValueBuy })_{\mathrm{i}, \mathrm{j}, \mathrm{t}}=\alpha+\beta_{1}$ Post Allowance $_{\mathrm{i}, \mathrm{j}, \mathrm{t}}+\gamma \mathrm{X}+\varepsilon_{\mathrm{i}, \mathrm{j}, \mathrm{t}}$

In line with the results in Table 2.5, Table 2.6 shows that insider purchasing activity is significantly higher in the month following the allowance date than in the month leading up to the allowance date. These findings indicate that insiders exploit the foreknowledge of future patent grants for their personal trading decisions. The estimated coefficients on the control variables in Table 2.6 lead to similar inferences as those in Table 2.5.

\subsubsection{Insider purchasing in the month after the allowance date compared to insider purchasing in the month prior to the allowance date for post-AIPA patents}

In this section, we perform similar analyses as in the previous section but focus on patents that were applied for after the AIPA came into force. First, we select a sample with only those post-AIPA patents that were not published before the allowance date and estimate models (2a) and $(2 b)$ on this sample. For the patents in this sample, information asymmetry at the allowance date is high and we expect to find similar trading behavior as in the previous section.

Table 2.7 reports the results of this analysis. As expected, for those post-AIPA patents that were not published prior to the allowance date, we observe a similar insider purchasing behavior compared to those patents that were applied for prior to the AIPA. That is, insider purchasing activity in the month after the allowance date is significantly higher than insider purchasing activity in the month leading up to the allowance date. 


\begin{tabular}{|c|c|c|c|c|}
\hline & (1) & (2) & (3) & (4) \\
\hline & \multicolumn{2}{|c|}{ IndBuy } & \multicolumn{2}{|c|}{ Ln(ValueBuy) } \\
\hline Post Allowance & $\begin{array}{c}0.0159 * * * \\
(2.85)\end{array}$ & $\begin{array}{c}0.0160 * * * \\
(2.86)\end{array}$ & $\begin{array}{c}0.2021 * * * \\
(3.03)\end{array}$ & $\begin{array}{c}0.2029 * * * \\
(3.04)\end{array}$ \\
\hline Ln(Allowance Lag) & $\begin{array}{c}0.0014 \\
(0.11)\end{array}$ & $\begin{array}{c}0.0033 \\
(0.29)\end{array}$ & $\begin{array}{c}0.0085 \\
(0.06)\end{array}$ & $\begin{array}{c}0.0450 \\
(0.34)\end{array}$ \\
\hline Safe & $\begin{array}{c}0.0808 * * * \\
\quad(5.84)\end{array}$ & $\begin{array}{c}0.0833 * * * \\
\quad(5.96)\end{array}$ & $\begin{array}{c}0.9619^{* * *} \\
(5.59)\end{array}$ & $\begin{array}{c}0.9908^{* * * *} \\
(5.71)\end{array}$ \\
\hline Ln(Market Cap) & $\begin{array}{c}0.0195^{* * *} \\
\quad(3.10)\end{array}$ & $\begin{array}{c}-0.0008 \\
(-0.05)\end{array}$ & $\begin{array}{c}0.2359 * * * \\
(3.09)\end{array}$ & $\begin{array}{c}-0.0237 \\
(-0.13)\end{array}$ \\
\hline $\mathrm{B} / \mathrm{M}$ & $\begin{array}{c}0.0608 * * \\
(2.37)\end{array}$ & $\begin{array}{c}0.0482 \\
(1.01)\end{array}$ & $\begin{array}{c}0.8217 * * \\
(2.38)\end{array}$ & $\begin{array}{c}0.6737 \\
(1.07)\end{array}$ \\
\hline RND/Sales & $\begin{array}{c}0.0024 \\
(0.93)\end{array}$ & $\begin{array}{c}0.0254 \\
(0.80)\end{array}$ & $\begin{array}{c}0.0266 \\
(0.94)\end{array}$ & $\begin{array}{c}0.3183 \\
(0.88)\end{array}$ \\
\hline Past Returns & $\begin{array}{c}-0.0637 * * * \\
(-2.66)\end{array}$ & $\begin{array}{c}-0.0476^{*} \\
(-1.87)\end{array}$ & $\begin{array}{c}-0.6961^{* *} \\
(-2.25)\end{array}$ & $\begin{array}{c}-0.5212 \\
(-1.61)\end{array}$ \\
\hline Ln(Analysts) & $\begin{array}{c}-0.0330 * * * \\
(-2.69)\end{array}$ & $\begin{array}{c}-0.0088 \\
(-0.32)\end{array}$ & $\begin{array}{c}-0.3556^{* *} \\
(-2.51)\end{array}$ & $\begin{array}{c}-0.0488 \\
(-0.15)\end{array}$ \\
\hline Constant & $\begin{array}{c}-0.1164 \\
(-0.40)\end{array}$ & $\begin{array}{c}0.1649 \\
(0.57)\end{array}$ & $\begin{array}{c}-2.8860 \\
(-1.00)\end{array}$ & $\begin{array}{c}0.9068 \\
(0.30)\end{array}$ \\
\hline Observations & 7,680 & 7,680 & 7,680 & 7,680 \\
\hline R-squared & 0.055 & 0.031 & 0.055 & 0.031 \\
\hline Industry Fixed Effects & Yes & No & Yes & No \\
\hline Firm Fixed Effects & No & Yes & No & Yes \\
\hline Application Year Fixed Effects & Yes & Yes & Yes & Yes \\
\hline Allowance Year Fixed Effects & Yes & Yes & Yes & Yes \\
\hline $\begin{array}{l}\text { OLS regressions of insider purc } \\
\text { by firm. T-statistics in parenthe } \\
\text { (two-tailed). The sample cor } \\
\text { (AIPA). Two observations per } \\
\text { during which only insiders kn } \\
\text { allowance date which is the con } \\
\text { month and zero otherwise. 'Ln(V } \\
\text { month. 'Post Allowance' is equa } \\
\text { the allowance date. 'Ln(Allowa } \\
\text { allowance date. 'Safe' is equ } \\
\text { quarterly earnings announcemen } \\
\text { book-to-market ratio at the en } \\
\text { revenue at the end of the prior fi } \\
\text { beginning of the month. 'Ln(An }\end{array}$ & $\begin{array}{l}\text { fore and the } 1 \\
\text { ote statistical } \\
\text { t patents appl } \\
\text { is: The first o } \\
\text { be granted. T } \\
\text { an indicator } ~ \\
1 \text { logarithm o } \\
\text { owing the all } \\
\text { logarithm of } \\
\text { oefore/after th } \\
\text { )' is the mark } \\
\text { Ir. 'RND/Sale } \\
\text { ' is the buy-a } \\
\text { aatural logarit } \\
\text { eginning of t }\end{array}$ & $\begin{array}{l}\text { after the all } \\
\text { icance at the } \\
\text { prior to the } \\
\text { tion represer } \\
\text { ond observa } \\
\text { e equal to } 1 \\
\text { lus the dolla } \\
\text { e date and ec } \\
\text { Imber of day } \\
\text { wance date o } \\
\text { talization at } \\
\text { search and d } \\
\text { d stock retur } \\
\text { one plus the } \\
\text { hth. }\end{array}$ & $\begin{array}{l}\text { e date. Standa } \\
0.05 \text {, and } 0.1 \\
\text { ican Inventor } \\
\text { month after } t \\
\text { epresents the } \\
\text { e is insider pu } \\
\text { e of insider p } \\
\text { zero in the } n \\
\text { een the appli } \\
\text { os with the fir } \\
\text { d of the prior } \\
\text { oment expens } \\
\text { the six mont } \\
\text { er of analysts }\end{array}$ & $\begin{array}{l}\text { rors clustered } \\
\text { respectively } \\
\text { ection Act } \\
\text { lowance date } \\
\mathrm{h} \text { before the } \\
\text { ing in a given } \\
\text { sing in a given } \\
\text { leading up to } \\
\text { date and the } \\
\text { nth after a } \\
\text { th. 'B/M' is the } \\
\text { led by sales } \\
\text { ding up to the } \\
\text { wing the firm }\end{array}$ \\
\hline
\end{tabular}




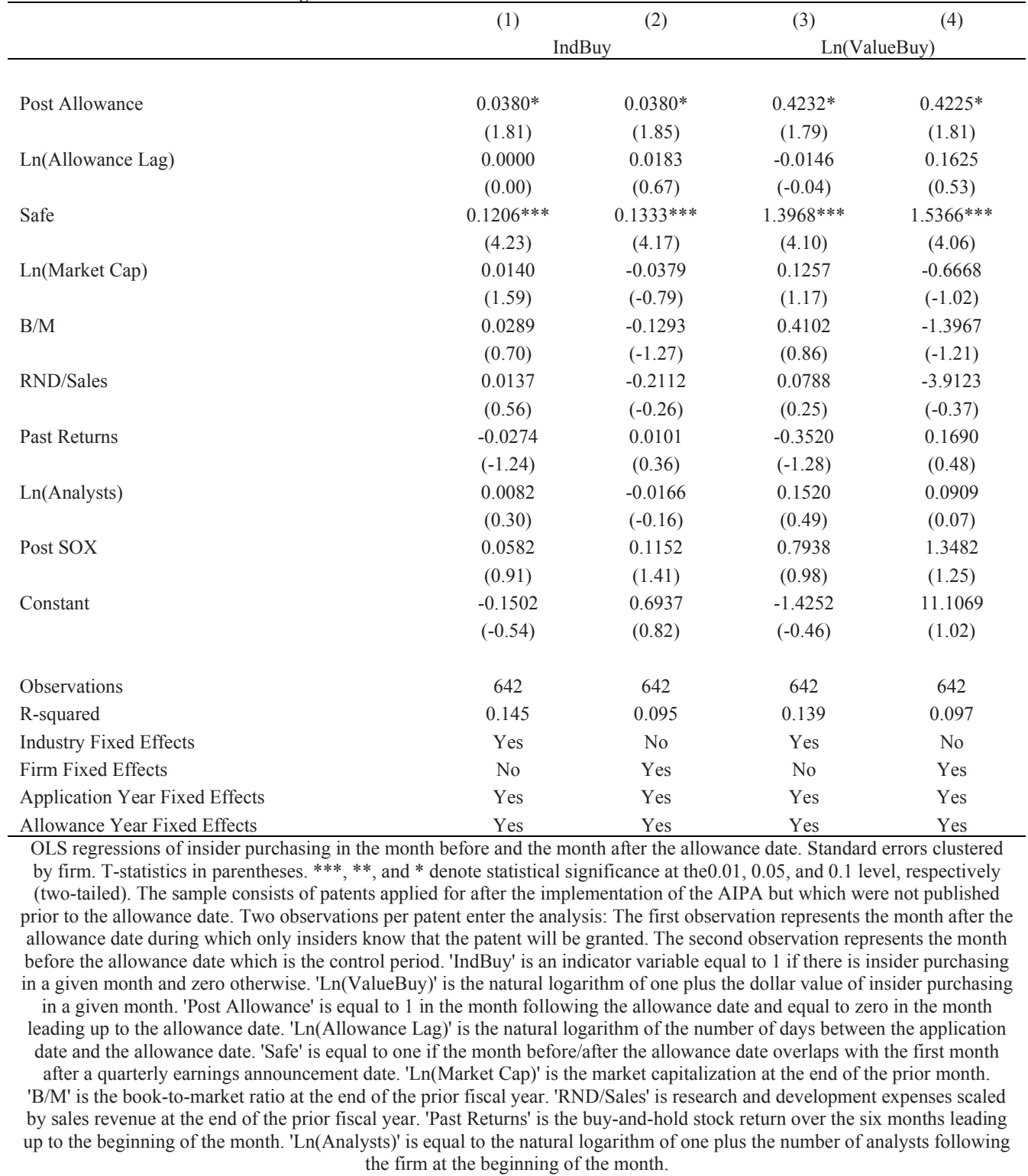

Next, we select another sample that is comprised of all patents applied for after the AIPA. This sample also includes patents whose applications were published before the patent allowance and for which information asymmetry after the allowance date should, thus, be lower. Hence, we use exogenous variation in the amount of information asymmetry between insiders and outsiders to identify the causal effect of the receipt of the patent allowance 
notification on insider purchasing behavior. For this sample, we estimate the following models and report the results in Table 2.8.

Table 2.8. Insider Purchasing Before and After the Allowance Date Conditional on Publication. Post-AIPA

\begin{tabular}{|c|c|c|c|c|}
\hline & (1) & (2) & (3) & (4) \\
\hline & \multicolumn{2}{|c|}{ IndBuy } & \multicolumn{2}{|c|}{ Ln(ValueBuy) } \\
\hline Post Allowance & $\begin{array}{c}0.0380 * \\
(1.81)\end{array}$ & $\begin{array}{c}0.0382 * \\
(1.83)\end{array}$ & $\begin{array}{c}0.4228 * \\
(1.78)\end{array}$ & $\begin{array}{c}0.4255^{*} \\
(1.80)\end{array}$ \\
\hline Publication Before Allowance & $\begin{array}{l}0.0190 \\
(0.98)\end{array}$ & $\begin{array}{c}0.0223 \\
(0.96)\end{array}$ & $\begin{array}{c}0.2224 \\
(0.88)\end{array}$ & $\begin{array}{l}0.2793 \\
(0.93)\end{array}$ \\
\hline Post Allowance * Publication Before Allowance & $\begin{array}{c}-0.0443^{*} \\
(-1.78)\end{array}$ & $\begin{array}{c}-0.0444 * \\
(-1.79)\end{array}$ & $\begin{array}{c}-0.4980 * \\
(-1.72)\end{array}$ & $\begin{array}{c}-0.4990^{*} \\
(-1.73)\end{array}$ \\
\hline Ln(Allowance Lag) & $\begin{array}{c}-0.0356^{*} \\
(-1.84)\end{array}$ & $\begin{array}{c}-0.0131 \\
(-0.72)\end{array}$ & $\begin{array}{c}-0.4198 * \\
(-1.85)\end{array}$ & $\begin{array}{c}-0.1846 \\
(-0.85)\end{array}$ \\
\hline Safe & $\begin{array}{c}0.0886^{* * *} \\
(5.09)\end{array}$ & $\begin{array}{c}0.0917 * * * \\
\quad(5.03)\end{array}$ & $\begin{array}{c}1.0240^{* * *} \\
(5.18)\end{array}$ & $\begin{array}{c}1.0647 * * * \\
(5.16)\end{array}$ \\
\hline Ln(Market Cap) & $\begin{array}{c}0.0110^{*} \\
(1.71)\end{array}$ & $\begin{array}{c}0.0119 \\
(0.40)\end{array}$ & $\begin{array}{c}0.1140 \\
(1.64)\end{array}$ & $\begin{array}{c}0.1081 \\
(0.28)\end{array}$ \\
\hline $\mathrm{B} / \mathrm{M}$ & $\begin{array}{r}-0.0217 \\
(-0.76)\end{array}$ & $\begin{array}{c}0.0122 \\
(0.23)\end{array}$ & $\begin{array}{c}-0.1960 \\
(-0.61)\end{array}$ & $\begin{array}{c}0.2795 \\
(0.40)\end{array}$ \\
\hline RND/Sales & $\begin{array}{l}0.0011 \\
(0.59)\end{array}$ & $\begin{array}{l}0.0309 \\
(1.20)\end{array}$ & $\begin{array}{c}0.0126 \\
(0.57)\end{array}$ & $\begin{array}{l}0.3475 \\
(1.28)\end{array}$ \\
\hline Past Returns & $\begin{array}{r}-0.0315 \\
(-1.63)\end{array}$ & $\begin{array}{c}-0.0514^{*} \\
(-1.85)\end{array}$ & $\begin{array}{c}-0.3621 \\
(-1.59)\end{array}$ & $\begin{array}{c}-0.6188^{*} \\
(-1.81)\end{array}$ \\
\hline Ln(Analysts) & $\begin{array}{c}-0.0009 \\
(-0.07)\end{array}$ & $\begin{array}{c}0.0002 \\
(0.00)\end{array}$ & $\begin{array}{l}0.0125 \\
(0.08)\end{array}$ & $\begin{array}{c}0.0836 \\
(0.12)\end{array}$ \\
\hline Post SOX & $\begin{array}{l}0.0377 \\
(0.86)\end{array}$ & $\begin{array}{c}0.0444 \\
(0.92)\end{array}$ & $\begin{array}{l}0.5781 \\
(1.06)\end{array}$ & $\begin{array}{c}0.6258 \\
(1.11)\end{array}$ \\
\hline Constant & $\begin{array}{l}0.1662 \\
(0.88)\end{array}$ & $\begin{array}{c}-0.1335 \\
(-0.27)\end{array}$ & $\begin{array}{l}1.7741 \\
(0.89)\end{array}$ & $\begin{array}{c}-1.4096 \\
(-0.23)\end{array}$ \\
\hline Observations & 2,786 & 2,786 & 2,786 & 2,786 \\
\hline R-squared & 0.111 & 0.041 & 0.113 & 0.041 \\
\hline Industry Fixed Effects & Yes & No & Yes & No \\
\hline Firm Fixed Effects & No & Yes & No & Yes \\
\hline Application Year Fixed Effects & Yes & Yes & Yes & Yes \\
\hline Allowance Year Fixed Effects & Yes & Yes & Yes & Yes \\
\hline
\end{tabular}


OLS regressions of insider purchasing in the month before and the month after the allowance date. Standard errors clustered by firm. T-statistics in parentheses. ***, **, and * denote statistical significance at the $0.01,0.05$, and 0.1 level, respectively (twotailed). The sample consists of all high-impact patents applied for after the American Inventors Protection Act (AIPA). Two observations per patent enter the analysis: The first observation represents the month after the allowance date during which only insiders know that the patent will be granted. The second observation represents the month before the allowance date which is the control period. 'IndBuy' is an indicator variable equal to 1 if there is insider purchasing in a given month and zero otherwise. 'Ln(ValueBuy)' is the natural logarithm of one plus the dollar value of insider purchasing in a given month. 'Post Allowance' is equal to 1 in the month following the allowance date and equal to zero in the month leading up to the allowance date. 'Publication Before Allowance' is an indicator variable equal to 1 if the patent publication preceded the allowance date and 0 otherwise. 'Post Allowance* Publication Before Allowance' is the interaction term between 'Post Allowance' and 'Patent Publication Before Allowance'. 'Ln(Allowance Lag)' is the natural logarithm of the number of days between the application date and the allowance date. 'Safe' is equal to one if the month before/after the allowance date overlaps with the first month after a quarterly earnings announcement date. ' $\mathrm{Ln}$ (Market Cap)' is the market capitalization at the end of the prior month. 'B/M' is the book-to-market ratio at the end of the prior fiscal year. 'RND/Sales' is research and development expenses scaled by sales revenue at the end of the prior fiscal year. 'Past Returns' is the buy-and-hold stock return over the six months leading up to the beginning of the month. 'Ln(Analysts)' is equal to the natural logarithm of one plus the number of analysts following the firm at the beginning of the month.

$$
\begin{aligned}
& \text { IndBuy }_{\mathrm{i}, \mathrm{j}, \mathrm{t}}=\alpha+\beta_{1} \text { Post Allowance }_{\mathrm{i}, \mathrm{j}, \mathrm{t}}+\beta_{2} \text { Publication Before Allowance }_{\mathrm{i}, \mathrm{j}, \mathrm{t}}+ \\
& \beta_{3} \text { Post Allowance } * \text { Publication Before Allowance } \text { Pl, }_{\mathrm{j}, \mathrm{t}}+\gamma \mathrm{X}+ \\
& \varepsilon_{\mathrm{i}, \mathrm{j}, \mathrm{t}}
\end{aligned}
$$

$$
\begin{aligned}
& \operatorname{Ln}\left(\text { ValueBuy }_{\mathrm{i}, \mathrm{j}, \mathrm{t}}=\alpha+\beta_{1} \text { Post Allowance }_{\mathrm{i}, \mathrm{j}, \mathrm{t}}+\beta_{2}{\text { Publication Before } \text { Allowance }_{\mathrm{i}, \mathrm{j}, \mathrm{t}}+}_{\beta_{3} \text { Post Allowance } * \text { Publication Before Allowance }}+\mathrm{i,j, \textrm {t }}+\gamma \mathrm{X}+\varepsilon_{\mathrm{i}, \mathrm{j}, \mathrm{t}}\right.
\end{aligned}
$$

In line with the findings in Tables 2.6 and 2.7, the results in Table 2.8 document that insider purchasing activity after the allowance date is significantly higher than insider purchasing activity before the allowance date for those patents that were not published prior to the allowance date. However, when the patent application is published before the allowance date, the difference in insider purchasing activity between the month after the allowance date and the month before the allowance date is reduced significantly such that insider purchasing activity after the allowance date is no different from insider purchasing activity before the allowance date.

These findings support the prediction that insiders exploit superior information about future patent grants that they receive with the patent allowance during the patent application process. The findings also show that this insider trading behavior is mitigated when patent applications are published prior to the receipt of the patent allowance because this mandatory and exogenous publication reduces information asymmetry between insiders and outsiders with respect to pending patent applications.

\subsection{Conclusion}

In this paper we document a causal relation between private information acquired by corporate insiders during the patent application process and their subsequent insider trading behavior. Specifically, we show that insiders are more likely to purchase shares after the USPTO privately communicates to the applying firm that a pending high impact patent will be granted. In addition, we show that insiders' decision to purchase shares subsequent to this private communication is conditional on exogenous variation in the level of information 
asymmetry between insiders and outsiders regarding pending patent applications. This exogenous variation arises due to a regulatory change in the US patent system, which mandates publication for pending patent applications within eighteen months after the application date.

This study makes contributions to at least three distinct streams of the literature. First, we contribute to the discussion on the sources of insider trading profits. While prior studies investigating insider trading based on private information have to assume that insiders are better informed than other market participants (e.g. Ke et al., 2003), we know exactly when information asymmetry between insiders and outsiders arises. We complement Aboody \& Lev (2000) who show that insiders in R\&D intensive firms generate greater trading profits than insiders in other firms.

Next, we contribute to a young but growing stream of the literature that shows that equitybased management compensation encourages managers to spur innovation efforts (Lerner and Wulf, 2007; Francis et al., 2011; Manso, 2011; Ederer and Manso, 2012). While these studies establish a link between ex-ante equity incentives and innovation output, we document a relation between innovation output and insiders' subsequent equity portfolio decisions. This link is important because if insiders were not able to trade on their knowledge of future patent grants, their equity incentives would trigger less innovation efforts ex-ante.

Lastly, we contribute to a discussion on the costs and benefits of the American Inventors Protection Act, which was enacted in November 1999 (Johnson and Popp, 2003). The act requires publication of patent applications applied for on or after November 29, 2000, no later than 18 months after the application date (USPTO, 1999). The reported results point to a supposedly beneficial side effect of this act, namely that it reduces insiders' ability to trade on private information generated by the patent application process. Specifically, if mandatory publication of the patent application by the USPTO takes place before the allowance date, then information asymmetry between insiders and outsiders will be substantially reduced. 



\title{
Insider Trading Against Mispricing of Public Information
}

\begin{abstract}
Although extant literature documents that insiders generate abnormal trading profits, the question remains whether these profits stem solely from private information or whether insiders also exploit sentiment-driven mispricing of publicly available information. In this study, I focus on the latter explanation for insider trading profits. Building on prior research that shows that market-wide investor sentiment causes firm-level mispricing of publicly disclosed information, I predict and find that insiders trade on mispricing of public information. Moreover, I find that insider trading against mispricing is stronger in firms for which market-wide sentiment causes greater mispricing. The evidence presented in this study implies that practitioners can screen insider purchase and insider sale disclosures for signals about under- and overvaluation. Additionally, the results caution against the perception that insider trades and insider trading profits are necessarily due to insiders exploiting private information for their personal trading decisions.
\end{abstract}




\subsection{Introduction}

Prior research shows that insiders earn abnormal returns on their transactions (Seyhun, 1986; Jeng et al., 2003; Cohen et al., 2012) and presents at least two explanations for these returns. First, insiders have private information about future cash flows. This explanation is tested in chapter two of this dissertation and by prior research (Elliott et al., 1984; Givoly and Palmon, 1985; Ke et al., 2003; Piotroski and Roulstone, 2005; Cohen et al., 2012). The second potential explanation for insiders' abnormal trading profits is that insiders are able to identify mispricing of publicly-available information. This mispricing partly arises because investors are subject to sentiment - which is loosely defined as general optimism or pessimism in the stock market (Baker and Wurgler, 2006) - and thus interpret publicly available information in an optimistic or pessimistic fashion. Extant empirical results regarding this explanation for insider trading profits are difficult to interpret and inconsistent: Studies that find that insiders trade contrarian on mispricing proxy for this mispricing with firm level measures that allow for alternative explanations (Rozeff and Zaman, 1998; Jenter, 2005; Piotroski and Roulstone, 2005). Furthermore, Jiang and Zaman (2010) find little evidence that aggregate insider trading reflects contrarian trading against sentiment-driven mispricing.

In this study, I focus on the second explanation for insider trading profits. I assume that the dominant goal of insider trading is to generate trading profits (Frankel and Li, 2004) and examine whether corporate insiders trade against mispricing. Given that firm-level mispricing is difficult to measure, I rely instead on proxies for market-wide investor sentiment (Baker and Wurgler, 2006, 2007) and argue that firm-level mispricing and market-wide sentiment are correlated. I document that insiders buy less shares and/or sell more shares after upward shifts in sentiment, that is, when their firms' shares are more likely to be overvalued. Similarly, insiders buy more shares and/or sell fewer shares after downward shifts in sentiment, that is, when their firms' shares are more likely to be undervalued. Furthermore, I find that the relation between investor sentiment and insider trading is driven by firms that are affected more strongly by investor sentiment. I find that these results hold across different proxies for market-wide mispricing, for aggregate time-series regressions as well as for panel regressions, and for insider purchases as well as insider sales.

In this study, I contribute to at least two different literature streams. First, I add to prior research that examines whether insiders trade against mispricing. Prior literature uses firm level measures such as the book-to-market ratio of equity and past stock returns as proxies for sentiment-driven mispricing and finds that insiders trade against it (Rozeff and Zaman, 1998; Jenter, 2005; Piotroski and Roulstone, 2005). However, past stock returns and the book-tomarket ratio might be related to insider trading because they reflect information about future cash-flow news (La Porta et al., 1997; Ali et al., 2011; Veenman, 2012). In addition, the bookto-market ratio might be related to insider selling because growth firms provide more equitybased compensation (Core and Guay, 1999). Furthermore, high past stock returns might trigger selling by insiders who want to realize the paper gains on their equity portfolio (Ofek and Yermack, 2000). Circumventing the problem of ambiguous firm-level measures of mispricing, Jiang and Zaman (2010) decompose realized market returns into expected return, unexpected cash flow news, and unexpected interest rate news. In contrast to earlier studies they find little evidence that insiders trade contrarian on sentiment-driven mispricing.

I contribute to this literature by documenting that insiders trade against mispricing as proxied by waves in market-wide investor sentiment. Measuring sentiment at the market level 
provides at least two benefits: First, I circumvent the problems associated with firm-level measures of mispricing such as the book-to-market ratio or past stock returns. Second, by identifying firms whose valuations are affected more strongly by investor sentiment, I can study cross-sectional variation in the relation between sentiment and insider trading. Baker and Wurgler $(2006,2007)$ show that firms that are more difficult to value and arbitrage are affected more strongly by investor sentiment. By documenting that insider trading against mispricing is stronger in difficult to value and arbitrage firms, I provide corroborating evidence that insiders are able to identify and trade against investor sentiment and I contribute to a second stream of the literature that documents cross-sectional differences in insider trading patterns and profits (Aboody and Lev, 2000; Frankel and Li, 2004; Huddart and Ke, 2007; Ben-David and Roulstone, 2010).

In a concurrent paper, Hribar and Quinn (2013) document that the insider trading behavior of CEOs is associated with annual changes in investor sentiment. In contrast to their work, I follow prior literature and examine the trading behavior of all corporate executives and board members, not only CEOs'. It is unclear why only CEOs - but not for example the CFO's trading behavior should be related to sentiment in the stock market. Since Hribar and Quinn relate annual changes in CEO trading to annual changes in sentiment, they disregard monthly variation in the investor sentiment data and cannot rule out that insider trading happens in the beginning of the year but sentiment only changes towards the end of the year. I circumvent this concern by relating insider trading in a given month to trends (or waves) in investor sentiment during prior months. Furthermore, Hribar and Quinn handpick only a few of the firm characteristics that Baker and Wurgler (2006) suggest are associated with the difficulty to value and arbitrage firms while I consider all of those proxies. In these tests of crosssectional variation in the relation between sentiment and insider trading, Hribar and Quinn omit the main effects of interaction terms, making their results difficult to interpret. Lastly, I show that both insider purchases and insider sales are associated with sentiment-driven mispricing while Hribar and Quinn only show results for an aggregate net insider purchasing measure. Separating purchases and sales is informative since prior research argues that only insider purchases - but not insider sales - are related to private information (Lakonishok and Lee, 2001; Jeng et al., 2003; Frankel and Li, 2004). Since insider trading against sentimentdriven mispricing should be distinct from insider trading on private information it is important to document - as I do in this study - that the relation between insider trading and sentiment is not solely driven by insider purchases.

In the remainder of this paper I proceed as follows. In the next section, I discuss relevant prior research and develop the hypotheses. Section 3 describes the data and sample that is used to test the hypotheses. Section 4 presents the main empirical results. Section 5 contains additional analyses and robustness tests and Section 6 concludes.

\subsection{Literature Review and Hypothesis Development}

\subsubsection{Sentiment in the stock market}

Sentiment-driven mispricing occurs when prices do not reflect economic fundamentals because investors are optimistic or pessimistic. To illustrate this, assume that the price of an asset is equal to the expected value of its discounted payouts 
where $\mathrm{m}$ is the discount factor and payouts $\mathrm{x}$ follow a probability density function which is objectively correct but about which individual investors have subjective beliefs. Investors whose subjective beliefs are correct are said to feature zero sentiment, while investors whose subjective beliefs are incorrect are said to feature nonzero sentiment (Shefrin, 2008). The former type of investor is commonly referred to as arbitrageur, while the latter type is termed noise trader (DeLong et al., 1990). Over time the nonzero sentiment of noise traders can fluctuate between degrees of optimism and pessimism. Optimistic sentiment implies expected payouts that are biased upward and pessimistic sentiment means that expected payoffs are biased downward.

While the existence of investors who are subject to sentiment is a necessary condition for persistent mispricing in capital markets, this condition is not sufficient. For sentiment-driven mispricing to persist in capital markets, betting against sentiment has to be risky and costly. Otherwise, rational arbitrageurs would take positions that correct any mispricing (DeLong et al., 1990; Lee et al., 1991). Arbitrage is risky because the unpredictability of noise traders' beliefs (that is the unpredictability of sentiment) creates a risk in the price of the asset. If noise-traders' beliefs about future payouts are correlated across asset classes and across individuals, then the risk from changes in investor sentiment cannot be diversified. This undiversifiable noise trader risk discourages rational arbitrageurs from aggressively betting against sentiment. Furthermore, arbitrageurs have incentives to delay betting against sentiment and instead ride sentiment waves in order to time the market (Abreu and Brunnermeier, 2003; Brunnermeier and Nagel, 2004). Hence, sentiment can persist in stock markets for some time and prices will only slowly revert back to fundamentals (cf. DeLong et al., 1990; Lee et al., 1991; Shefrin, 2008).

I assume that corporate insiders believe that prices do not always reflect the true economic value of the underlying securities. Furthermore, I assume that insiders are sophisticated market participants who observe when outside investors become increasingly optimistic or pessimistic about their firms' shares. That is, insiders observe the increase in optimism or pessimism that is caused by 'waves' in investor sentiment, which Baker and Wurgler (2006) loosely define as uninformed demand shocks in the presence of arbitrage constraints. Information about order backlog or cost developments that insiders acquire about their firms might aid them in identifying firm-specific mispricing.

Insiders who trade in their own firms' shares to generate trading profits have an incentive to adjust their insider trading behavior according to whether they perceive outside market participants as becoming increasingly optimistic or pessimistic about firms' prospects.

\subsubsection{Insider trading and mispricing}

Extant empirical research that investigates whether insiders trade on mispricing includes Rozeff and Zaman (1998), Jenter (2005), Piotroski and Roulstone (2005), Jiang and Zaman (2010) and Veenman (2012). The results from these studies are inconclusive, however. Jenter (2005), Rozeff and Zaman (1998) and Piotroski and Roulstone (2005) find that insiders sell more shares in growth stocks and when past returns are high and buy more shares in value stocks and when past returns are low. The studies conclude that insiders do trade contrarian on 
mispricing of public information. As discussed above, these results are subject to alternative explanations that are unrelated to mispricing. In a European setting, Veenman (2012) shows that insiders trade against firm level mispricing where mispricing is measured based on a residual income valuation model. In contrast to these studies, Jiang and Zaman (2010) find little evidence that aggregate insider trading reflects contrarian strategies to exploit market level mispricing.

Given recent evidence against the hypothesis that insiders, on aggregate, trade contrarian (Jiang and Zaman, 2010) and criticism of the measures used in the literature to identify firm level mispricing, I revisit this question. To avoid the problems of firm-specific mispricing proxies, I use market-level data on monthly changes in investor sentiment (e.g. Baker and Wurgler, 2006, 2007) to identify waves in investor sentiment and assume that these waves in market-level sentiment are correlated with firm-specific mispricing.

As discussed above, I assume that insiders observe the mispricing that sentiment waves create. Optimistic waves in sentiment (i.e. positive demand shocks) imply that firms either become less underpriced, which in turn leads to less insider buying, or that firms become more overpriced, leading to more insider selling. Similarly, pessimistic sentiment-waves (i.e. negative demand shocks) imply that firms either become less overpriced, leading to less insider selling, or that firms become more underpriced, causing more insider buying. Taken together, this means that insiders increase their equity holdings when outside market participants turn more pessimistic about the shares of the insiders' firms and decrease their holdings when the market becomes more optimistic.

\section{H1. Insiders trade against mispricing of publicly available information.}

\subsubsection{Insider trading in difficult to value and arbitrage firms}

Behavioral finance literature proposes that the effect of investor sentiment on firm valuations is stronger for firms that are more difficult to value and arbitrage (Baker and Wurgler, 2006, 2007, 2012). For firms that are difficult to value, investors can justify a wider range of valuations than for firms in which the fundamentals are easier to identify. Risky firms without close substitutes whose valuation is subjective are more difficult to arbitrage because arbitrage necessitates the availability of close substitutes and because for these firms the risk that sentiment pushes prices even further away from fundamentals in the future is greater. In practice, the most difficult to value stocks are also those that are hardest to arbitrage (Baker and Wurgler, 2006). If waves in investor sentiment cause greater mispricing in firms that are more difficult to value and arbitrage, insiders of these firms trade more strongly against mispricing than insiders of other firms. Thus, I test the following hypothesis:

H2. The relation between insider trading and mispricing is more pronounced among firms that are difficult to value and arbitrage.

\subsection{Sample and Data}

In the following, I describe the sample selection procedure and the calculation of the main variables and controls that are used in the analyses of Hypotheses 1 and 2. Since I use marketlevel data on waves in investor sentiment to proxy for mispricing, I first examine the relation 
between mispricing and aggregate insider trading in time-series analyses, followed by an examination of mispricing and firm-level insider trading.

\subsubsection{Sample selection and variables for analyses of insider trading patterns and profits}

The sample period for this study is January 1986 to December 2010. 1986 is the first year for which insider transactions are available in the Thomson Reuters Insiders Disclosure Data Feed and 2010 is the last year for which data on the investor sentiment index developed by Baker and Wurgler $(2006,2007)$ is available. Thomson Reuters gathers all insider transactions reported to the US Securities and Exchange Commission (SEC). In line with prior literature, I collect open market purchases and sales conducted by corporate officers and directors. ${ }^{16}$ In line with Lakonishok and Lee (2001) and Frankel and Li (2004), I aggregate purchases and sales by calculating the net purchase ratio (NPR) as the value of purchases less sales divided by the value of purchases plus sales. For the time-series analysis, I calculate NPR for each month and for the firm-level analyses for each firm-month: ${ }^{17}$

$N P R=\frac{V A L U E_{-} B U Y-V A L U E_{-} S E L L}{V A L U E_{-} B U Y+V A L U E_{-} S E L L}$

To proxy for mispricing, I draw upon the monthly sentiment-changes index developed in Baker and Wurgler $(2006,2007)$, which is constructed from six time series. These are NYSE trading volume, dividend premium, closed-end fund discount, number of IPOs and first-day returns on IPOs, and equity share in new issues. The sentiment-changes index is the first principal component of the changes in the six proxies, orthogonalized to macro-economic fundamentals such as growth in the industrial production index, growth in consumer durables, nondurables, and services, and a dummy variable for recessions. ${ }^{18}$

Since I expect insiders to observe firm-specific mispricing that is caused by sentiment waves, I use the Baker and Wurgler sentiment-changes index and take the number of consecutive monthly same-sign changes in investor sentiment to identify sentiment waves. For example, if sentiment increased in month $t-7$ but has decreased in each of the months $t-6$ through $t-1$, then the measure for investor sentiment waves (IS) is equal to -6 . Similarly, if investor sentiment decreased in month $t-5$ but has increased in each of the months $t-4$ through $t-1$, then IS is equal to +4 . In other words, IS is the number of consecutive monthly increases (decreases) in sentiment since the last decrease (increase) in the sentiment index. The longer the string of consecutive monthly increases (decreases) in sentiment, the more persistent the

\footnotetext{
${ }^{16}$ To eliminate potentially problematic records in the insider trading date feed, I clean the data according to the instructions in Jeng et al. (2003).

${ }^{17}$ I follow prior studies (Lakonishok and Lee, 2001; Frankel and Li, 2004; Piotroski and Roulstone, 2005) and drop firmmonths without any insider trading for which NPR cannot be calculated.

${ }^{18}$ The rationale for using these six time series to construct a sentiment index is as follows: Sentiment is higher when trading volume is greater because it is usually optimistic noise traders who drive up trading volume (Baker and Wurgler, 2007). Sentiment is lower when the dividend premium is higher since dividend-paying stocks are closer to bonds in terms of their risk profile than non-dividend paying stocks. Closed-end funds are investment firms that issue a fixed number of shares on stock exchanges. The closed-end fund discount is the difference between the net asset value of a fund's security holdings and its market price (Baker and Wurgler, 2007). If closed-end funds are primarily held by retail investors then a discount on these funds represents adverse investor sentiment (Neal and Wheatley, 1998). The number of IPOs and first-day returns on IPOs are increasing in investor sentiment. Finally, the equity share in new issues is positively correlated with investor sentiment as firms try to issue new equity when they perceive their shares to be overpriced.
} 
optimistic (pessimistic) sentiment wave. Optimistic (pessimistic) sentiment waves are likely to lead to overpricing (underpricing).

In robustness tests, I use data on consumer sentiment to proxy for mispricing. Specifically, I use data on the Michigan Consumer Sentiment Index which is based on a questionnaire administered to US households that asks respondents about their personal economic outlook. Similar to the investor sentiment index developed by Baker and Wurgler (Baker and Wurgler, 2006, 2007), the Michigan Consumer Sentiment Index is also measured monthly and I use the number of consecutive monthly same-sign changes in consumer sentiment to identify consumer sentiment waves (CS).

Baker and Wurgler (2006) identify ten different characteristics that are related to the difficulty to value and arbitrage firms. These are firm size, proxied by market capitalization, firm age, the book-to-market ratio of equity, sales growth, R\&D expenditures scaled by total assets, asset tangibility defined as the book value of property, plant, and equipment scaled by total assets, external finance needs measured as the change in assets minus the change in retained earnings divided by assets, stock return volatility over the prior twelve months, an indicator for loss-making firms, and an indicator for dividend paying firms. Firms are more difficult to value and arbitrage if they are small, young, high R\&D expenditures and low asset tangibility, high external finance needs, high volatility, are unprofitable, and pay no dividends. The book-to-market ratio wears at least two hats: A low ratio implies the existence of growth options while a high ratio implies financial distress. Both firms with significant growth options and firms in distress are likely to be difficult to value and arbitrage. The same is true with sales growth since high sales growth implies growth options and negative sales growth implies distress.

In line with Cornell et al. (2011), I use principal component analysis to generate a composite measure for the difficulty to value and arbitrage stocks (DVA). DVA is the common component of the ten proxies identified by Baker and Wurgler. The principal component has an eigenvalue of 2.76 and the correlations with the ten measures range between -0.02 (sales growth) and 0.71 (no dividends). Following Baker and Wurgler (2006), I create decile ranks of the difficult to value and arbitrage proxies to limit the influence of measurement error and outliers.

In the time-series regressions, I control for the natural logarithm of the value of the S\&P 500 at the beginning of the month $(\mathrm{Ln}(\mathrm{S} \& \mathrm{P}$ Index Value $))$ as well as for the performance of the S\&P 500 over the past six months (Past Market Return). Similarly, I control for the natural logarithm of share price at the beginning of the month $\operatorname{Ln}$ (Price) and for share price performance over the past six months (Past Return) in the firm-level analyses. These controls serve to control for insider buying (selling) when prices are low (high) or past performance was bad (good) that is not related to mispricing. In the firm-level regressions, I also control for the decile rank of market capitalization (Market Cap) and the decile rank of the book-tomarket ratio (BTM) as well as industry fixed effects. ${ }^{19}$ All specifications include a time trend.

\footnotetext{
${ }^{19}$ All variables that are transformed into deciles for the regression analyses are displayed in raw form in the descriptive statistics in Table 1.
} 


\subsection{Empirical Results}

\subsubsection{Descriptive statistics}

Table 3.1 provides descriptive statistics for all variables described above. Panel A contains the variables for the time-series analyses and Panel B the variables for the firm-level analyses. Panels A and B both reveal that insiders sell more shares than they buy. This is due to the sales of shares that insiders did not purchase on the open market but obtained via restricted stock or stock option grants as a form of compensation. Panel B reveals that NPR which is by construction bound to lie between -1 and 1 , takes on these values for a significant amount of observations. While this structure of the data might suggest the use of nonlinear models such as Tobit, I use OLS in all firm-level model specifications for three reasons: First, Hypothesis 2 requires statistical tests of interaction terms and Greene (2010) advises against hypothesis testing on interaction terms in nonlinear models. Second, two-dimensional clustering of standard errors in Tobit models with left-censoring at -1 and right-censoring at 1 is not straightforward. Third, Tobit models assume the existence of a latent variable that can take on values outside of the observable range (in the case at hand, outside of the range -1 and 1). In the study at hand, the existence of such as latent variable does not seem plausible. ${ }^{20}$ While not displayed in Table 3.1, IS ranges from -10 through 8 . The two longest pessimistic sentiment waves occurred after the burst of the dotcom bubble and after the stock market crash on 'Black Monday' in October 1987.

\subsubsection{Market level relation between mispricing and aggregate insider trading}

In this section, I test for a relation between mispricing and aggregate insider trading. The market level analysis is instructive since investor sentiment is a market-wide phenomenon and supposedly impacts share prices of a variety of firms in the market. Thus, I test whether insiders on aggregate buy more and/or sell less after pessimistic sentiment waves and sell more and/or buy less after optimistic sentiment waves.

Since the sentiment index of Baker and Wurgler (Baker and Wurgler, 2006, 2007) is by construction orthogonal to economic fundamentals, I do not need to add economic fundamentals as additional regressors. Since insiders might trade contrarian on past market returns, I control for the return on the market over the past six months (Past Market Return) and separately for the return over the prior month $(\operatorname{Lag}(\Delta \mathrm{S} \& \mathrm{P} 500))$. In addition, I include the lag of the dependent variable $((\operatorname{Lag}(\mathrm{NPR}))$ in order to control for unobserved correlated variables. Lastly, I control for common linear time trends (Trend). This leads to the following time-series model, which I test with ordinary least squares and heteroskedasticity-consistent standard errors. ${ }^{21}$

$$
\begin{aligned}
& \mathrm{NPR}_{\mathrm{t}}=\alpha+\beta_{1} \mathrm{IS}_{\mathrm{t}}+\beta_{2} \operatorname{Lag}(\mathrm{NPR})_{\mathrm{t}}+\beta_{3} \text { Past Market Return }{ }_{\mathrm{t}}+\beta_{4} \operatorname{Lag}(\Delta \mathrm{S} \& P \text { Value })_{\mathrm{t}}+ \\
& \beta_{5} \text { Trend }_{t}+\varepsilon_{\mathrm{t}}
\end{aligned}
$$

\footnotetext{
${ }^{20}$ The interested reader is referred to section 3.4.2 in Angrist and Pischke (2008) for a discussion of tobit models and their appropriateness in different research settings.

${ }^{21}$ In untabulated analyses, I find that inferences remain unchanged when using Newey-West heteroskedasticity- and autocorrelation-consistent standard errors with maximum lag orders of up to three periods.
} 
Table 3.1: Summary Statistics of Main Variables

\begin{tabular}{|c|c|c|c|c|c|c|}
\hline & Mean & SD & 25 & Median & 75 & $\mathrm{n}$ \\
\hline \multicolumn{7}{|c|}{ Panel A: Economy-month level } \\
\hline NPR & -0.821 & 0.167 & -0.928 & -0.868 & -0.761 & 300 \\
\hline IS & -0.103 & 2.854 & -2.000 & -1.000 & 2.000 & 300 \\
\hline $\mathrm{CS}$ & -0.310 & 2.186 & -2.000 & -1.000 & 1.000 & 300 \\
\hline Past Market Return & 0.043 & 0.118 & -0.023 & 0.048 & 0.120 & 300 \\
\hline S\&P Index Value & 823.525 & 416.497 & 410.745 & 897.855 & 1182.265 & 300 \\
\hline \multicolumn{7}{|c|}{ Panel B: Firm- month level } \\
\hline NPR & -0.373 & 0.910 & -1.000 & -1.000 & 1.000 & 250,648 \\
\hline Value Buy & 48414.456 & 814488.344 & 0.000 & 0.000 & 8111.721 & 250,648 \\
\hline Value Sell & 1054578.096 & 12468799.529 & 0.000 & 59156.077 & 420042.349 & 250,648 \\
\hline IS & -0.065 & 2.788 & -2.000 & -1.000 & 2.000 & 250,648 \\
\hline $\mathrm{CS}$ & -0.346 & 2.181 & -2.000 & -1.000 & 1.000 & 250,648 \\
\hline Price & 15.734 & 114.254 & 5.302 & 11.863 & 21.014 & 250,648 \\
\hline Past Return & 0.112 & 0.402 & -0.119 & 0.067 & 0.271 & 250,648 \\
\hline Market Cap & 3405.456 & 16729.811 & 81.711 & 347.559 & 1450.625 & 250,648 \\
\hline BTM & 0.575 & 0.564 & 0.271 & 0.458 & 0.718 & 250,648 \\
\hline Firm Age & 17.550 & 15.948 & 6.255 & 12.342 & 23.263 & 250,648 \\
\hline Asset Tangibility & 0.277 & 0.237 & 0.086 & 0.208 & 0.407 & 250,648 \\
\hline Profit & 0.877 & 0.329 & 1.000 & 1.000 & 1.000 & 250,648 \\
\hline Dividend Payer & 0.411 & 0.492 & 0.000 & 0.000 & 1.000 & 250,648 \\
\hline Volatility & 0.134 & 0.085 & 0.077 & 0.113 & 0.166 & 250,648 \\
\hline External Financing & 0.102 & 0.290 & -0.008 & 0.056 & 0.163 & 250,648 \\
\hline Sales Growth & 0.485 & 28.617 & 0.016 & 0.118 & 0.277 & 250,648 \\
\hline $\mathrm{R} \& \mathrm{D}$ & 0.046 & 0.103 & 0.000 & 0.000 & 0.054 & 250,648 \\
\hline DVA & -0.000 & 1.000 & -0.738 & -0.056 & 0.572 & 250,648 \\
\hline
\end{tabular}

Net Purchase Ratio (NPR)' is the dollar value of insider purchases less the value of insider sales divided by the value of insider purchases plus insider sales. 'IS' ('CS') is the number of consecutive monthly same-sign changes in investor (consumer) sentiment up to the beginning of the current month. For example, if investor sentiment increased in month t-7 but has decreased in any of months $\mathrm{t}-6$ through $\mathrm{t}-1$, then IS is equal to -6 . Similarly, if investor sentiment decreased in month $\mathrm{t}-5$ but has increased in any of months t-4 through t-1, then IS is equal to +4. 'Past Market Return' is the buy-and-hold return on the S\&P 500 over the prior six months. 'S\&P Index Value' is the value of the S\&P500 at the beginning of the month. 'Value Buy' is the dollar value of insider purchases. 'Value Sell' is the dollar value of insider sales. 'Price' is the share price at the beginning of the month. 'Past Return' is the buy-and-hold stock return over the prior six months. 'Market Cap' is firm market capitalization. 'BTM' is the book-to-market ratio. 'Firm Age' is the number of years since the firm first appeared on CRSP. 'Asset Tangibility' is the book value of property, plant, and equipment scaled by total assets. 'Profit' is an indicator that is equal to one if the firm had positive return on assets in the last fiscal year and equal to zero otherwise. 'Dividend' is an indicator variable equal to one if the firm paid a dividend in the last fiscal year and equal to zero otherwise. 'Volatility' is the stock return volatility of the past twelve months. 'External Financing' is measured as the change in assets minus the change in retained earnings divided by assets. 'Sales Growth' is the annual change in net sales divided by last year's net sales. 'R\&D' is research and development expenses scales by assets. 'DVA' is the principal component of the prior ten variables and measures the difficulty to value and arbitrage stocks.

Table 3.2 reveals that the coefficient on the proxy for mispricing (IS) is negative and significant across different model specifications with different sets of control variables. This implies that corporate insiders increase (decrease) their equity holdings when the valuations of the insiders' firms are likely to be pessimistic (optimistic), which provides support for Hypothesis 1. I also find that insiders on aggregate sell more and/or buy less when the return on the market in the prior month is high. 
Table 3.2: The Effect of Investor Sentiment on Aggregate Insider Trading

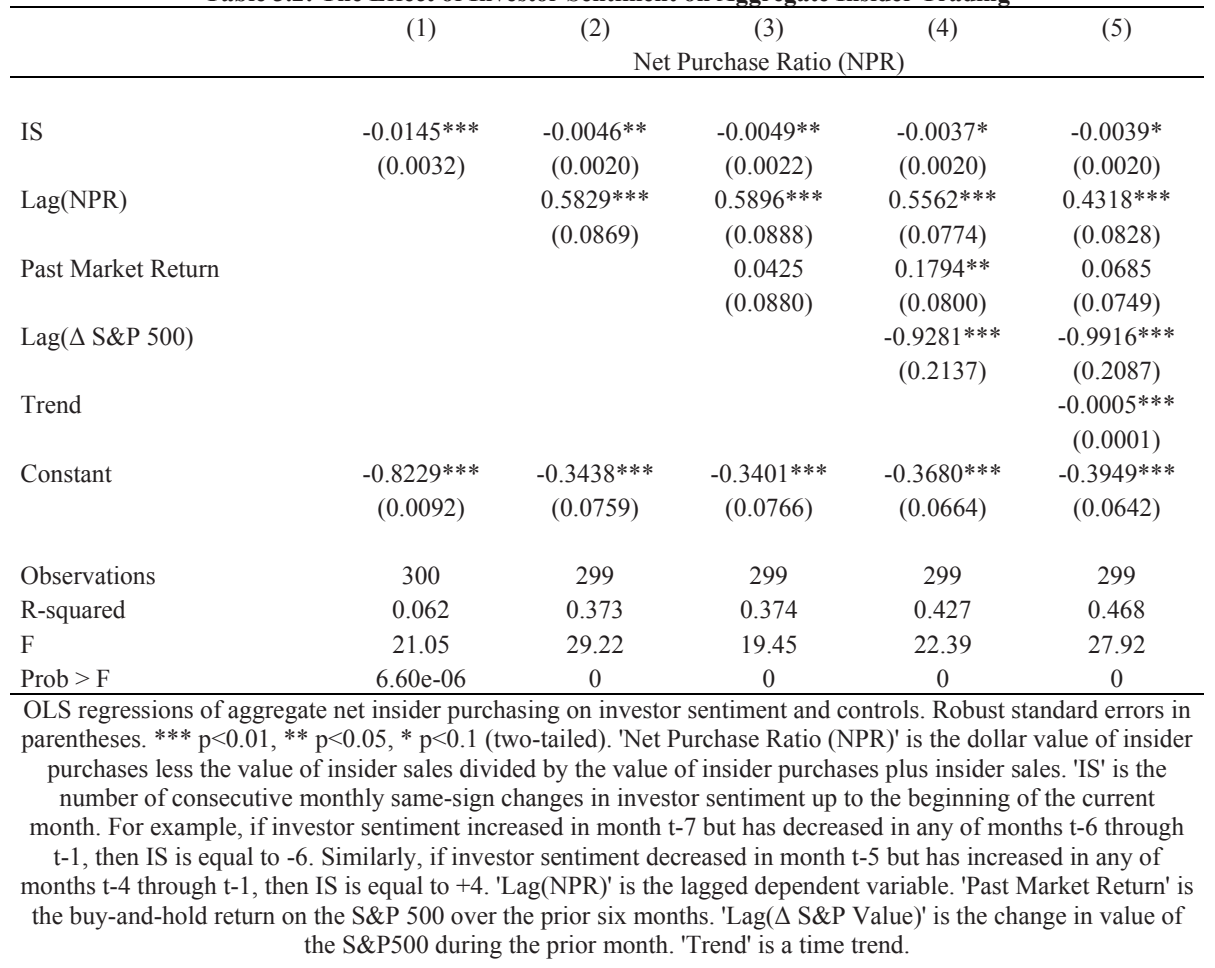

\subsubsection{Firm level relation between mispricing and insider trading}

I now turn to firm level analyses, which allow testing for cross-sectional variation in the relation between insider trading and mispricing. As discussed above, I expect insider trading against mispricing to be more pronounced among firms that are difficult to value and arbitrage because these firms are most likely to be influenced by sentiment waves. To test this hypothesis, I estimate equation (4) with OLS for firm i and month t. In all firm level analyses, I cluster the standard errors by firm and month because standard errors are likely to be correlated across time within the same firm and because the investor sentiment variable only varies in the time-series but not in the cross section. In the absence of two-dimensional clustering, OLS would estimate the standard errors assuming more random variation than there actually is. Hence, the standard errors would be too small, inflating the t-statistics (Petersen, 2009; Gow et al., 2010).

$$
\begin{aligned}
& N P R_{i, t}=\alpha+\beta_{1} I S_{t}+\beta_{2} D V A_{i, t}+\beta_{3} I S * D V A_{i, t}+\beta_{4} \operatorname{Ln}\left(\text { Price }_{i, t}+\beta_{5} \text { Past Return }_{i, t}+\right. \\
& +\beta_{6} \text { Market Cap }_{i, t}+\beta_{7} \text { BTM }_{i, t}+\beta_{8} \text { Trend }_{t}+\text { Industry FE }+\varepsilon_{i, t}
\end{aligned}
$$

where Industry FE represents industry fixed effects based on two-digit SIC codes. All other variables are as defined above. The results are reported in Table 3.3.

Models 1 and 2 in Table 3.3 reveal that the on-average effect of mispricing on net insider purchasing is negative and significant, which corroborates the results in Table 3.2. Hence, 
insiders, on average, buy more shares and/or sell fewer shares when the valuations of their firms are likely to be pessimistic and sell more shares and/or buy fewer shares when the valuations of their firms are likely to be optimistic. These results provide support for Hypothesis 1.

Models 3 and 4 of Table 3.3 test for cross-sectional differences in the relation between insider trading and mispricing. The negative and significant coefficient on IS*DVA implies that insider trading against mispricing is an increasing function of the difficulty to value and arbitrage the firm. Sentiment-driven mispricing is greater in difficult to value and arbitrage firms and, hence, insiders have a greater incentive to trade against mispricing in these firms than in others. This result supports Hypothesis 2. The main effect of IS is insignificant in Models 3 and 4, which implies that the on average effect observed in Models 1 and 2 is driven by insiders in difficult to value and arbitrage firms.

In line with prior literature, NPR is negatively related to share price and past stock returns across all four models. Furthermore, insiders buy less in smaller firms and more in firms with high book-to-market ratios. As Piotroski and Roulstone (2005) argue, insider selling when past returns are high and buying when the book-to-market ratio is high could indicate that insiders trade contrarian on mispricing. They acknowledge, however, that past returns and the book-to-market ratio might proxy for future cash flow news rather than mispricing. Specifically, La Porta et al. (1997) find that firms with negative past returns and high book-tomarket ratios experience positive future earnings announcement returns. In addition, book-tomarket and past returns might be related to insider trading for reasons related to insiders' diversification concerns (Smith and Watts, 1992; Ofek and Yermack, 2000; Ali et al., 2011; Veenman, 2012). By employing a proxy for mispricing that is unrelated to firm characteristics, I provide direct evidence that insiders trade contrarian against mispricing.

\subsection{Additional analyses and robustness checks}

\subsubsection{Insider purchasing versus insider selling}

Prior literature on insider trading suggests that insider purchases and insider sales are driven by different motives. For example, Jeng et al. (2003) find that insider purchases generate abnormal returns while insider sales do not and Lakonishok and Lee (2001) observe that the predictive ability of insider transactions for future returns is higher for purchases than for sales. The authors argue that insiders might sell for various reasons that are unrelated to information such as liquidity or diversification concerns. Similarly, Frankel and Li (2004) suggest that insider purchase are more likely than insider sales to reflect trading motivated by private information.

In addition, the legal jeopardy that is associated with selling shares shortly before the release of negative news about the firm is likely to be higher than the legal jeopardy associated with buying shares shortly before the disclosure of positive news. The reason is that the former supposedly causes greater public outrage than the latter if losses borne by current shareholders loom larger than gains forgone by former shareholders. 
Net Purchase Ratio (NPR)

\begin{tabular}{|c|c|c|c|c|}
\hline IS & $\begin{array}{c}-0.0208^{* * *} \\
(0.0048)\end{array}$ & $\begin{array}{c}-0.0139^{* * *} \\
(0.0034)\end{array}$ & $\begin{array}{l}-0.0026 \\
(0.0060)\end{array}$ & $\begin{array}{l}-0.0051 \\
(0.0044)\end{array}$ \\
\hline DVA & & $\begin{array}{c}-0.0377 * * * \\
(0.0025)\end{array}$ & $\begin{array}{c}0.0237 * * * \\
(0.0026)\end{array}$ & $\begin{array}{c}-0.0378 * * * \\
(0.0025)\end{array}$ \\
\hline IS * DVA & & & $\begin{array}{c}-0.0033 * * * \\
(0.0006)\end{array}$ & $\begin{array}{c}-0.0016^{* * *} \\
(0.0006)\end{array}$ \\
\hline $\operatorname{Ln}$ (Price) & & $\begin{array}{c}-0.2549 * * * \\
(0.0078)\end{array}$ & & $\begin{array}{c}-0.2551^{* * *} \\
(0.0077)\end{array}$ \\
\hline Past Return & & $\begin{array}{c}-0.3917 * * * \\
(0.0172)\end{array}$ & & $\begin{array}{c}-0.3894 * * * \\
(0.0173)\end{array}$ \\
\hline Market Cap & & $\begin{array}{c}-0.0296 * * * \\
(0.0026)\end{array}$ & & $\begin{array}{c}-0.0295^{* * *} \\
(0.0026)\end{array}$ \\
\hline BTM & & $\begin{array}{c}0.0192 * * * \\
(0.0019)\end{array}$ & & $\begin{array}{c}0.0192 * * * \\
(0.0019)\end{array}$ \\
\hline Trend & & $\begin{array}{c}-0.0016^{* * *} \\
(0.0001)\end{array}$ & & $\begin{array}{c}-0.0016^{* * *} \\
(0.0001)\end{array}$ \\
\hline Constant & $\begin{array}{c}-0.3745^{* * *} \\
(0.0168)\end{array}$ & $\begin{array}{c}0.7944 * * * \\
(0.1224)\end{array}$ & $\begin{array}{c}-0.5051^{* * *} \\
(0.0224)\end{array}$ & $\begin{array}{c}0.7950 * * * \\
(0.1226)\end{array}$ \\
\hline Observations & 250,648 & 250,648 & 250,648 & 250,648 \\
\hline R-squared & 0.004 & 0.205 & 0.011 & 0.205 \\
\hline Industry FE & YES & YES & YES & YES \\
\hline F & 1043 & 922.4 & 867.9 & 911.3 \\
\hline Prob $>F$ & 0 & 0 & 0 & 0 \\
\hline
\end{tabular}

Since I argue that insider trading against mispricing is distinct from insider trading on superior or private information it is worthwhile to examine whether the relation between insider trading and mispricing holds for both, insider purchases and insider sales. Specifically, if the results reported in the prior sections are driven by mispricing of publicly available information then insider purchases and insider sales should both be related to mispricing. If, however, the above results are driven by private information, for example because insiders' possession of private information coincides with sentiment waves, then I expect to find insider purchases, but not insider sales, to be related to the mispricing proxy. In prior analyses, the aggregation of insider purchases and insider sales into the Net Purchase Ratio (NPR) did not allow for separation of the effect of mispricing on insider purchases and insider sales, respectively. In Table 3.4, I report the results of estimating the following two equations, analyzing insider purchasing behavior and insider selling behavior separately. 
Ln(Value Buy $)_{i, t}=\alpha+\beta_{1} I S_{t}+\beta_{2} D V A_{i, t}+\beta_{3} I S * D V A_{i, t}+\beta_{4} \operatorname{Ln}(\text { Price })_{i, t}+$ $\beta_{5}$ Past Return $_{i, t}++\beta_{6}$ Market Cap $_{i, t}+\beta_{7}$ BTM M $_{i, t}+\beta_{8}$ Trend $_{t}+$ Industry FE + $\varepsilon_{i, t}$

Ln $(\text { Value Sell })_{i, t}=\alpha+\beta_{1} I S_{t}+\beta_{2} D V A_{i, t}+\beta_{3} I S * D V A_{i, t}+\beta_{4} \operatorname{Ln}(\text { Price })_{i, t}+$ $\beta_{5}$ Past Return $_{i, t}++\beta_{6}$ Market Cap $_{i, t}+\beta_{7}$ BTM M $_{i, t}+\beta_{8}$ Trend $_{t}+$ Industry FE + $\varepsilon_{i, t}$

The results reported in Table 3.4 show that the relation between sentiment waves and insider trading is indeed driven by insider purchases as well as insider sales. Models 1 implies that insiders buy more shares when the valuations of their firms are likely to be pessimistic and Model 2 shows that insiders sell more shares when the valuations of their firms is likely to be optimistic. In addition, Models 2 and 4 indicate that insider purchasing when valuations are pessimistic and insider selling when valuations are optimistic are concentrated in firms that are difficult to value and arbitrage. These results mitigate concerns that the relation between insider trading and mispricing of publicly available information is confounded by insider trading on private information.

\subsubsection{Different difficult to value and arbitrage proxies}

Hypothesis 2 predicts that insiders in difficult to value firms trade more against mispricing because sentiment waves cause greater mispricing in these firms than in others. In this section, I test Hypothesis 2 using interaction terms between IS and each of the ten different proxies for the difficulty to value and arbitrage. These proxies are firm size, the book-to-market ratio, firm age, asset tangibility, profitability, R\&D intensity, dividends, stock return volatility, external financing needs, and sales growth. The estimation results of equation (7) are presented in Table 3.5 where 'Proxy' is one of the ten difficult to value and arbitrage proxies.

$$
\begin{aligned}
& N P R_{i, t}= \\
& \left.\alpha+\beta_{1} I S_{t}+\beta_{2} \text { Proxy }_{i, t}+\beta_{3} I S * \text { Proxy }_{i, t}+\beta_{4} \text { Ln }_{(\text {Price }}\right)_{i, t}+\beta_{5} \text { Past Return }_{i, t}+ \\
& +\beta_{6} \text { Market Cap }_{i, t}+\beta_{7} \text { BTM }_{i, t}+\beta_{8} \text { Trend }_{t}+\text { Industry FE }+\varepsilon_{i, t}
\end{aligned}
$$

Supporting Hypothesis 2, the coefficients on the interaction term IS*Proxy in Table 3.5 show that insider trading against mispricing is stronger in distressed firms (Model 2) and volatile firms (Model 7). Also in line with expectations, insider trading against mispricing is weaker in large firms (Model 1), old firms (Model 3), firms with high asset tangibility (Model 4), profitable firms (Model 5), and dividend-paying firms (Model 6). For external financing (Model 8) and research and development expenditures (Model 10), the coefficient on the interaction term is not statistically significant. For sales growth (Model 9) the coefficient is positive and significant at the ten percent level, suggesting that firms which are not in distress (i.e. firms with positive sales growth) are less mispriced. Overall, the results in Table 3.5 are in line with those in Table 2 and provide further support for Hypothesis 2. 


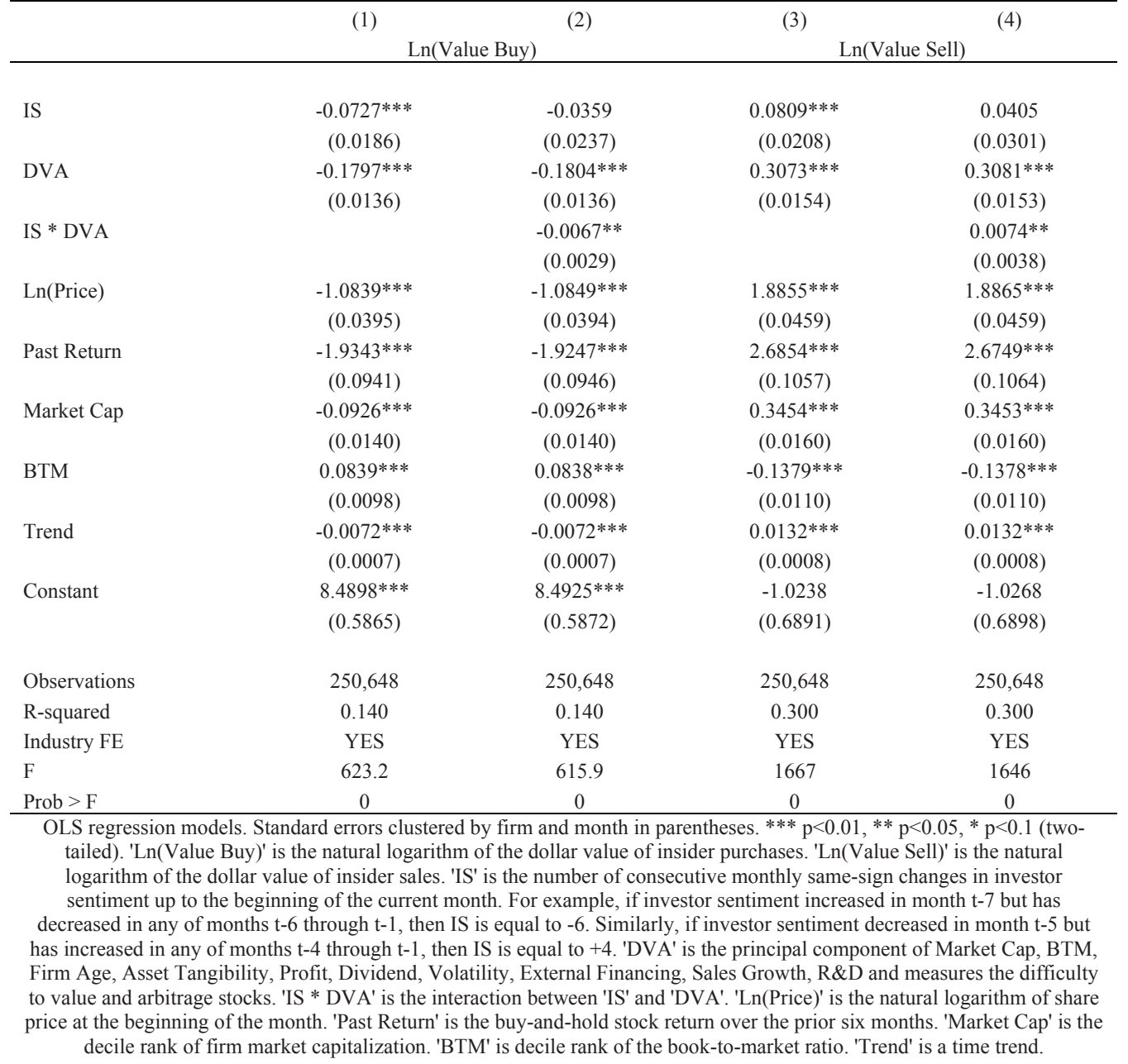

\subsubsection{The Michigan Consumer Sentiment Index}

In the above analyses, I used data on the investor sentiment index created by Baker and Wurgler $(2006,2007)$ to proxy for mispricing. The components of this index are market-wide time series such as the fraction of new equity issues in total capital issues per month or the number of IPOs per month. Since these variables are driven by managerial decisions to conduct IPOs or issue seasoned equity, there exists the possibility that insider trading and market sentiment are simultaneously determined. I use data from the Michigan Consumer Sentiment Index to validate the main result that insiders trade against sentiment-driven mispricing. To do so, I first estimate equation (8), which is similar to equation (3), where the variable IS is replaced by CS, which is the proxy for mispricing that is based on waves in 
consumer sentiment rather than investor sentiment. Similar to equation (3), equation (8) is estimated at the market level, that is, with aggregate insider trading.

$\mathrm{NPR}_{\mathrm{t}}=\alpha+\beta_{1} \mathrm{CS}_{\mathrm{t}}+\beta_{2} \operatorname{Lag}(\mathrm{NPR})_{\mathrm{t}}+\beta_{3}$ Past Market Return ${ }_{\mathrm{t}}+\beta_{4} \operatorname{Lag}(\Delta \mathrm{S} \& P \text { Value })_{\mathrm{t}}+$

$\beta_{5}$ Trend $_{t}+\varepsilon_{\mathrm{t}}$

The results in Table 3.6 reveal that waves in consumer sentiment are significantly negatively related to insider net purchasing only when one does not control for lagged insider net purchasing (Model 1). In all other model specifications, the coefficient on CS is negative as expected, but not statistically significant.

Next, I test the relation between consumer sentiment driven mispricing and insider trading at the firm level by estimating equation (9), which is similar to equation (4).

$$
\begin{gathered}
\left.N P R_{i, t}=\alpha+\beta_{1} C S_{t}+\beta_{2} D V A_{i, t}+\beta_{3} C S * D V A_{i, t}+\beta_{4} \text { Ln }_{(\text {Price }}\right)_{i, t}+\beta_{5} \text { Past Return }_{i, t} \\
++\beta_{6} \text { Market Cap }_{i, t}+\beta_{7} \text { BTM }_{i, t}+\beta_{8} \text { Trend }_{t}+\text { Industry FE }+\varepsilon_{i, t}
\end{gathered}
$$

The results of this analysis are presented in Table 3.7. Models 1 and 2 suggest that the average effect of sentiment-driven mispricing on insider trading is robust to using consumer sentiment as a proxy for mispricing. However, using consumer sentiment instead of investor sentiment as a proxy for mispricing, I do not find the effect of sentiment-driven mispricing on insider trading is stronger for difficult to value and arbitrage firms. 


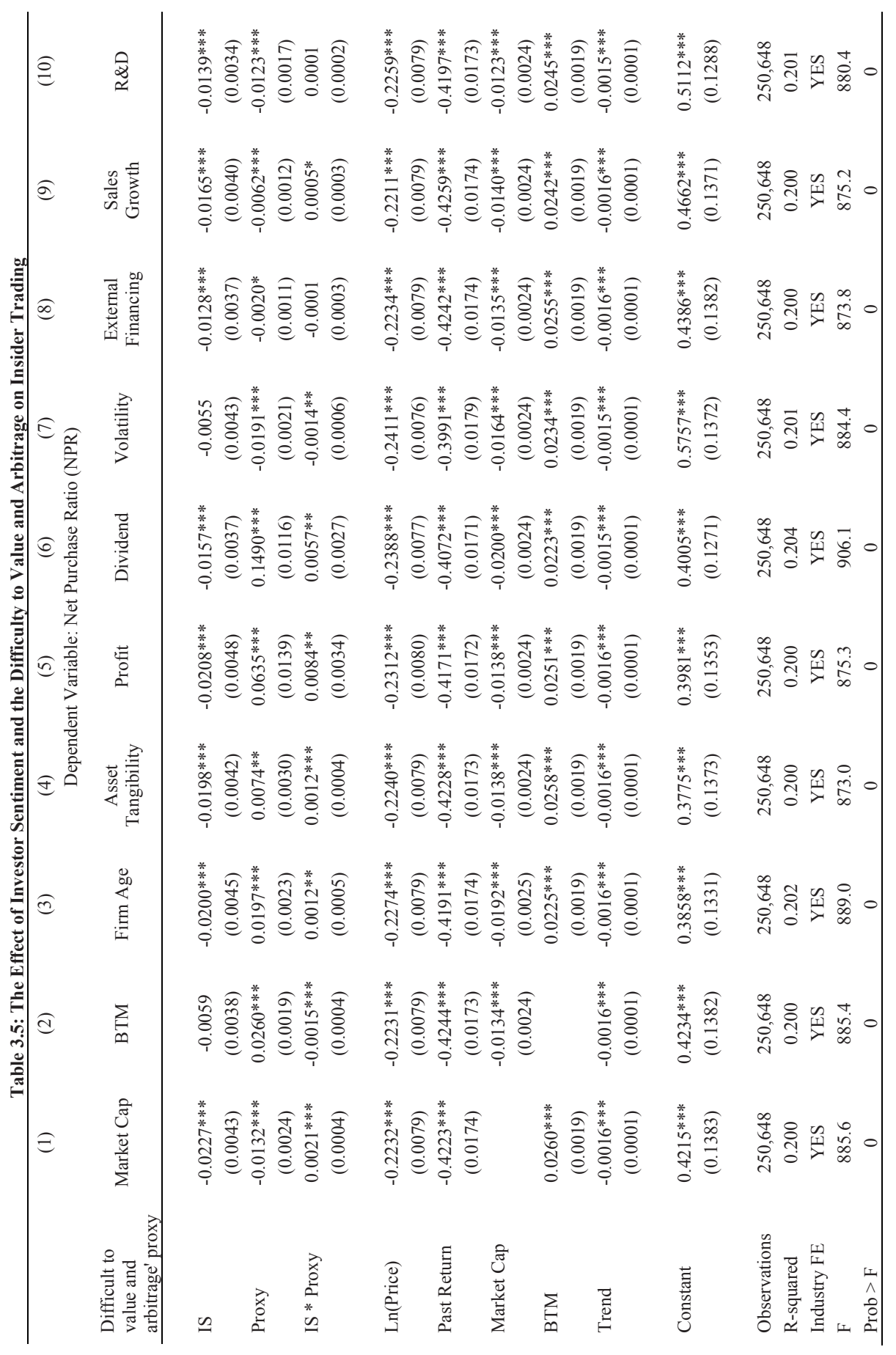




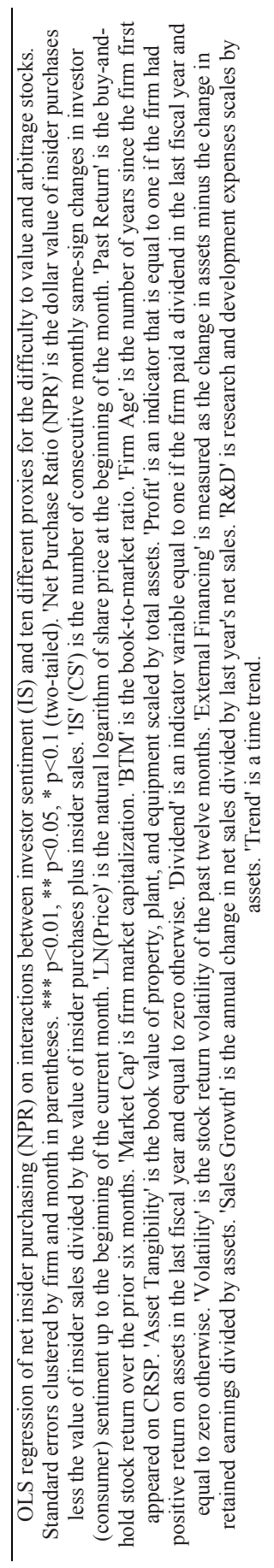


Table 3.6: The Effect of Consumer Sentiment on Aggregate Insider Trading

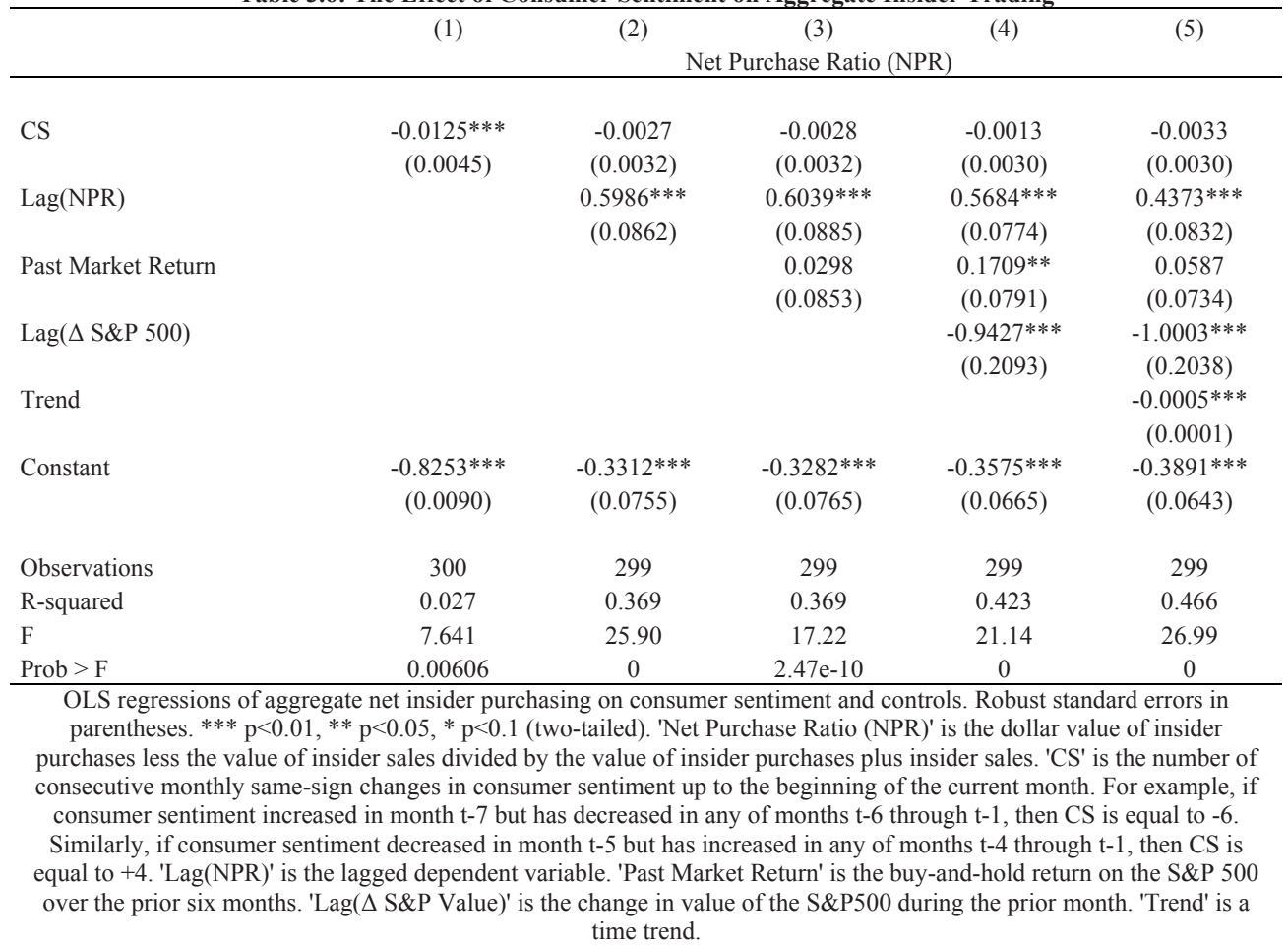

\subsection{Conclusion}

Prior research documents inconsistent results regarding the question whether corporate insiders trade against mispricing of publicly available information. Rozeff and Zaman (1998), Jenter (2005), and Piotroski and Roulstone (2005) proxy for mispricing using firm level measures that allow for alternative explanations. Furthermore, Jiang and Zaman (2010) find little evidence that aggregate insider trading reflects contrarian trading against sentimentdriven mispricing. In this study, I use exogenous variation in market-wide investor sentiment to proxy for firm level mispricing and show that corporate insiders trade against sentiment waves. More specifically, I show that insiders purchase shares when it is more likely that their 
Table 3.7: The Effect of Consumer Sentiment on Insider Trading at the Firm Level

(1)

\section{$-0.0156^{* *}$ \\ (0.0069)}

DVA

CS * DVA

Ln(Price)

Past Return

Market Cap

BTM

Trend

Constant

\section{Observations}

R-squared

Industry FE

F

Prob $>$ F
(2)

(3)

Net Purchase Ratio (NPR)
(4)

$\begin{array}{cc}-0.0086 & -0.0096^{*} \\ (0.0077) & (0.0057) \\ 0.0235^{* * *} & -0.0372 * * * \\ (0.0027) & (0.0026) \\ -0.0013 & -0.0000 \\ (0.0008) & (0.0007) \\ & -0.2546 * * * \\ & (0.0078) \\ & -0.3968^{* * *} \\ & (0.0166) \\ & -0.0291 * * * \\ & (0.0027) \\ & 0.0193 * * * \\ & (0.0019) \\ & -0.0017 * * * \\ & (0.0001) \\ -0.5079 * * * & 0.7918^{* * *} \\ (0.0223) & (0.1231)\end{array}$

250,648

0.007

YES

605.0
0.204

YES

900.4
250,648

OLS regression models. Standard errors clustered by firm and month in parentheses. ${ }^{* * *} \mathrm{p}<0.01,{ }^{* *} \mathrm{p}<0.05,{ }^{*} \mathrm{p}<0.1$ (twotailed). 'Net Purchase Ratio (NPR)' is the dollar value of insider purchases less the value of insider sales divided by the value of insider purchases plus insider sales. 'CS' is the number of consecutive monthly same-sign changes in consumer sentiment up to the beginning of the current month. For example, if investor sentiment increased in month $\mathrm{t}-7$ but has decreased in any of months $\mathrm{t}-6$ through $\mathrm{t}-1$, then IS is equal to -6 . Similarly, if investor sentiment decreased in month $\mathrm{t}-5$ but has increased in any of months t-4 through t-1, then IS is equal to +4. 'DVA' is the principal component of Market Cap, BTM, Firm Age, Asset Tangibility, Profit, Dividend, Volatility, External Financing, Sales Growth, R\&D and measures the difficulty to value and arbitrage stocks. 'CS * DVA' is the interaction between 'CS' and 'DVA'. 'Ln(Price)' is the natural logarithm of share price at the beginning of the month. 'Past Return' is the buy-and-hold stock return over the prior six months. 'Market Cap' is the decile rank of firm market capitalization. 'BTM' is decile rank of the book-to-market ratio. 'Trend' is a time trend.

firms' shares are undervalued (i.e. after decreases in sentiment) and sell shares when it is more likely that their firms' shares are overvalued (i.e. after increases in sentiment). These results hold across two different widely used proxies for sentiment. Since I show that these results are not solely driven by insider purchases but that insider sales are also associated with mispricing mitigates concerns that the results might be driven by trading on private information as opposed to trading on mispricing of publicly available information.

I contribute to the above-mentioned literature by documenting that insiders trade against mispricing as proxied by waves in market-wide investor sentiment. Measuring sentiment at the market level circumvents the problems associated with firm-level measures of mispricing such as the book-to-market ratio or past stock returns that are used in prior studies. Furthermore, by documenting that insider trading against mispricing is stronger in difficult to 
value and arbitrage firms, I provide corroborating evidence that insiders trade against sentiment-driven mispricing and I contribute to a second stream of the literature that documents cross-sectional differences in insider trading patterns and profits (Aboody and Lev, 2000; Frankel and Li, 2004; Huddart and Ke, 2007; Ben-David and Roulstone, 2010). The evidence presented in this study implies that practitioners can screen insider purchase and insider sale disclosures for signals about under- and overvaluation. Additionally, the results caution against the perception that insider trades and insider trading profits are necessarily due to insiders exploiting private information for their personal trading decisions. 




\title{
CEO Integrity and Insider Trading
}

\begin{abstract}
We investigate the relation between CEO integrity and CEO insider trading behavior. Following prior work, we measure out-of-integrity behavior by a CEO's excessive use of causation words in the CEO's annual letter to shareholders. Predicting that out-of-integrity CEOs trade on private information, we find that their trading profits are significantly higher than those of high-integrity CEOs. This result holds across a broad range of proxies for insider trading profitability and is stronger in firms with lower analyst monitoring. Consistent with the prediction that out-of-integrity CEOs trade on private information, we show that the trades of out-of-integrity CEOs predict quarterly earnings news, while the trades of highintegrity CEOs do not.
\end{abstract}




\subsection{Introduction}

Prior work documents how corporate insiders can achieve superior trading performance (Jaffe, 1974; Seyhun, 1986; Lakonishok and Lee, 2001; Jeng et al., 2003). An open question, however, is whether insider trading profits and insiders' propensity to trade on private information are related to insiders' personal characteristics. Understanding the relation between personal characteristics and insider trading behavior is important for at least two reasons: First, external market participants as well as the Securities and Exchange Commission (SEC) are interested in identifying trades that are likely to be motivated by private information. Second, a rapidly growing body of literature demonstrates that manager fixed effects are related to corporate policies and events (Bertrand and Schoar, 2003; Bamber et al., 2010; Dyreng et al., 2010; Graham et al., 2011) but little is known about which personal characteristics these fixed effects represent.

In this paper, we examine the relation between CEO integrity and CEO insider trading behavior. Management integrity has been argued to be one of the most important personal characteristics of corporate leaders and to affect firm performance and reporting quality (Dikolli et al., 2013; Erhard and Jensen, 2013). Using an empirical proxy developed and validated in Dikolli et al. (2013), we measure CEO integrity based on excessive causation words in a CEO's letter to corporate shareholders. Specifically, we regress a count of causation words in the CEO's shareholder letter on expected economic determinants of causation word usage, including the count of causation words used in a firm's Management Discussion and Analysis (MD\&A). As in Dikolli et al. (2013), the residual in this regression represents CEO integrity, where higher (lower) values of the residual represent out-ofintegrity ${ }^{22}$ (high-integrity) behavior.

We predict that out-of-integrity CEOs trade opportunistically on private information. We find that their trading profits from insider purchases, as measured by abnormal monthly returns, are significantly higher than those of high-integrity CEOs. Consistent with evidence that insider traders do not yield higher profits (than non-insiders) from insider sales due to exogenous reasons for selling (e.g., liquidity and diversification), we also show that out-ofintegrity CEOs do not make significantly higher trading profits from insider sales than those of high-integrity CEOs. This result holds across a broad range of proxies for insider trading profitability, including an annual profitability proxy developed in Skaife et al. (2012).

We also show that the negative relation between CEO integrity and annual profitability from insider purchases is stronger in firms with lower analyst monitoring. This suggests that out-of-integrity CEOs are able to exploit their private information more in settings where external monitoring is relatively low. Further, consistent with the prediction that out-ofintegrity CEOs trade on private information, we document that the trades of out-of-integrity CEOs predict quarterly earnings news, while the trades of high-integrity CEOs do not.

We make several contributions to the literature. First, we build on the recent findings of a significant relation between insider transaction types and insider trading profits. Cohen et al. (2012) empirically separate routine from opportunistic insider transactions and show that opportunistic trades are more profitable than routine trades. Cohen et al. (2012), however, do not address specific personal traits of the insider that may account for routine versus

\footnotetext{
${ }^{22}$ In the following, we use "out-of-integrity" and "low integrity" interchangibly.
} 
opportunistic trading behavior. ${ }^{23} \mathrm{We}$ add to this literature by conceptually linking opportunistic and out-of-integrity behavior. We then show empirically that out-of-integrity CEOs earn higher insider trading profits than high-integrity CEOs and that these profits are at least partially due to trading on private information.

Secondly, we contribute to the literature that examines the relation between CEO characteristics and firm policies (Bertrand and Schoar, 2003; Graham et al., 2011; Fee et al., 2013). While these studies show that CEO fixed effects are related to firm investments and compensation policies, it is unclear which personal traits of the CEO are captured in the fixed effects model. Our results suggest that integrity is an important personal characteristic that affects CEOs' insider trading behavior and might also have consequences for other corporate policies and events (cf. Dikolli et al., 2013).

The results of this study are also relevant to practitioners who develop investment strategies based on cues from public information about insider traders. For example, insider transactions are widely followed by external market participants and the business press. Websites provide extensive tracking of insider transactions and offer investment advice that is informed by insider transactions. ${ }^{24}$ Academic research also suggests that insider trading provides cues to external market participants. ${ }^{25}$ To the extent that the measure of CEO integrity used in this study is related to the characteristics of an insider transaction and is based on public information sources, the results of this study are useful in identifying ex-ante those insider transactions that are likely to be informative about future firm performance.

The remainder of this paper is structured as follows: In Section 2, we review prior literature and develop our hypotheses. In Section 3, we describe the sample, data, and methodologies used in our analyses. In Section 4, we present our empirical tests, and Section 5 concludes.

\subsection{Background and hypotheses}

In this section, we briefly review the prior literature on insider trading, the economic consequences of managerial traits, and the importance of integrity. We then apply the insights from this review to develop our hypotheses.

\subsubsection{Insider trading}

A considerable body of research has examined whether corporate insiders earn superior trading profits. For the most part, prior research documents that insiders are able to predict future stock price performance and earn abnormal profits on their trades (Jaffe, 1974; Seyhun, 1986; Lakonishok and Lee, 2001; Jeng et al., 2003). A notable exception is the study by Eckbo and Smith (1998), in which the authors find that insiders of Norwegian companies do not earn abnormal trading profits. One interpretation of the Eckbo and Smith (1998) findings is that cultural or personal characteristics may explain why abnormal insider trading profits are not observed in a sample of predominantly Norwegian individuals.

\footnotetext{
${ }^{23}$ Note, however, that Cohen et al (2012) do examine the role of an insider's home domicile, which could be interpreted as an indirect determinant of routine versus opportunistic insider trading behavior. An insider's home domicile, however, is unlikely to capture a specific trait of a CEO in the way that the integrity measure does.

${ }^{24}$ See for example http://www.insidermonkey.com or http://www.insider-monitor.com.

${ }^{25}$ For example, Brochet (2010) finds evidence of significant market reactions to initial insider trading disclosure through EDGAR and Rogers et al. (2013) document price and volume responses at the time when information about insider transactions is disseminated through DowJones newswire.
} 
The literature presents at least two explanations for insiders' ability to generate superior trading profits: First, insiders have private information about future cash flows and trade on this information. This explanation is examined in chapter 2 of this dissertation as well as in prior literature (Ke et al., 2003; Piotroski and Roulstone, 2005). Second, insiders are able to identify mispricing of publicly available information. This explanation is examined in chapter 3 of this dissertation as well as in prior work (Rozeff and Zaman, 1998; Jenter, 2005; Piotroski and Roulstone, 2005).

Prior insider trading literature also identifies cross-sectional variation in insider trading profitability. In particular, Frankel and Li (2004) and Huddart and Ke (2007) show that insiders trade less profitably when analysts' monitoring is high. More generally, prior research finds that insider trading profitability is increasing in information asymmetry (Aboody and Lev, 2000; Frankel and Li, 2004; Huddart and Ke, 2007) and decreasing in corporate governance quality (Jagolinzer et al., 2011) and internal control quality (Skaife et al., 2012). Instead of examining cross-sectional variation in insider trading profits at the firm-level, Cohen et al. (2012) classify insiders according to their prior trading behavior into routine and opportunistic. They find that the trades of opportunistic insiders predict future stock returns while the trades of routine insiders do not.

\subsubsection{Integrity and other managerial traits}

Beginning with Bertrand and Schoar (2003), researchers have recently paid increased attention to the importance of managerial traits for corporate policies, events, and outcomes. Bertrand and Schoar (2003) find that managerial fixed effects affect economic outcomes, investment policy, financial policy, and firm strategy. Graham et al. (2011) show that managerial fixed effects explain a sizeable part of the variation in executive pay, Bamber et al. (2010) document that managerial fixed effects are related to firms' voluntary disclosure strategies, and Dyreng et al. (2010) show that individual executives play a significant role in determining the level of tax avoidance that firms undertake.

A largely unresolved issue in these studies is the specific reasons for why the managerial fixed effects matter. Hence, a related stream of research examines the effect of specific managerial characteristics such as military experience (Bamber et al., 2010), overconfidence (Malmendier and Tate, 2005; Malmendier et al., 2011), and narcissism (Chatterjee and Hambrick, 2007) on corporate policies and events. In an insider trading context, Cohen et al. (2012) empirically classify corporate insider transactions as routine or opportunistic and find that opportunistic insiders trade more profitably than routine insiders.

In a series of papers, Jensen (2009), Erhard and Jensen (2013), and Erhard et al. (2013), discuss the importance of integrity for organizational performance. The authors interpret integrity as "honoring one's word", which implies that an individual does what he or she says they will do by the time they say they will do it, or, if not, the individual informs all parties involved immediately and resolves any problems that may subsequently arise. Erhard et al. (2013: 86) describe integrity as a necessary condition for maximum performance, arguing that "when integrity is impaired, the ability of a person, group, or entity to perform is impaired." A recent IBM survey of over 1,500 CEOs shows that CEOs themselves see integrity as the most essential leadership quality second only to creativity (IBM, 2010).

Erhard et al. (2013) further describe actions of an individual with low integrity: "Faced with the messes resulting from out-of-integrity behavior, people and organizations regularly 
avoid confronting the role of their out-of-integrity behavior as cause in the matter. Instead, they supply explanations, rationalizations, justifications and excuses that masquerade as causes for the messes actually created by out-of-integrity behavior" (p.84).

Based on this description of out-of-integrity behavior, Dikolli et al. (2013) construct an empirical proxy for CEO integrity that is based on the abnormal use of causation words in CEO's prose. After validating this integrity score with survey data, Dikolli et al. (2013) find that CEO integrity is positively related to accrual quality. In the following section, we motivate our hypotheses that integrity as a personal trait is related to both insider trading profitability and the propensity to trade on inside information.

\subsubsection{Hypothesis development}

The literature surveyed in the previous section defines integrity as "honoring one's word" and stresses the importance of integrity for organizational performance (Jensen, 2009; Erhard and Jensen, 2013; Erhard et al., 2013). This definition of integrity fits well with an insider trading setting since insiders such as CEOs owe fiduciary duty to their shareholders. Fiduciary duty implies that CEOs give their word to refrain from using private information to their own benefit and others' detriment. However, if CEOs use private information when trading with outside shareholders, they do not comply with their fiduciary duty, which means that they do not honor their word.

Prior research and chapter two of this dissertation identify trading on private information as one possible explanation for insiders' superior trading profits (Ke et al., 2003; Piotroski and Roulstone, 2005). Hence, we expect out-of-integrity insiders to make greater use of private information for their personal trading decisions and, hence, we expect these insiders to earn higher returns on their trades. ${ }^{26}$ To the extent that out-of-integrity insiders are conceptually similar to opportunistic managers, we similarly expect that out-of-integrity insiders will earn higher returns on their trades than other insiders, consistent with the intuition in Cohen et al. (2012). Formally, our first hypothesis is:

\section{H1. CEO integrity is negatively related to insider trading profitability.}

Prior research shows that insiders enjoy higher trading profits in environments that are characterized by high information asymmetry and low monitoring (Aboody and Lev, 2000; Frankel and Li, 2004; Huddart and Ke, 2007; Jagolinzer et al., 2011). In particular, analyst coverage has been shown to curtail insider trading profits by reducing the information asymmetry between insiders and outsiders (Frankel and Li, 2004; Huddart and Ke, 2007). Hence, insiders hold less private information in firms with high analyst coverage than in firms with low analyst coverage as increased monitoring assures that private information is incorporated into the share price earlier. Hence, the expected benefits from exploiting private information for insider trading purposes are lower in firms with high analyst coverage. The expected legal costs from insider trading on private information might also be higher in highcoverage firms if the SEC takes cues from analysts about potentially illegal actions taken by the firm or its key employees.

\footnotetext{
${ }^{26}$ On the other hand, if the abnormal insider trading profits observed in prior research are not due to trading on private information but are rather a result of insiders' ability to identify mispricing of publicly available information, integrity should be unrelated to insider trading profits.
} 
Hence, if the expected benefits (costs) from insider trading on private information are lower (higher) in high-coverage firms than in low-coverage firms we expect the difference in trading profits between out-of-integrity CEOs and high-integrity CEOs to be greater in firms with low analyst coverage than in firms with high analyst coverage.

H2. The relation between CEO integrity and insider trading profits is stronger in firms with low analyst monitoring.

As discussed above, CEO integrity should only be related to insider trading profits if CEOs use private information for their trading decisions. If CEOs are not relying on private information for their trades but rather trade on mispricing of publicly available information (cf. Rozeff and Zaman, 1998) then integrity is not expected to have any effect on insider trading profitability. However, the results presented in chapter two of this dissertation as well as the findings in other recent studies do imply that insiders trade on private information. For example, extant work shows that insiders trade on foreknowledge of future earnings realizations (Ke et al., 2003; Piotroski and Roulstone, 2005; Jagolinzer et al., 2011) and other firm-specific news events (Cohen et al., 2012). If the results presented above, namely that outof-integrity CEOs achieve higher insider trading profits than in-integrity CEOs, are driven by out-of-integrity CEOs' propensity to trade on private information, then we expect that the trades of out-of-integrity CEOs predict future news events. Following Jagolinzer et al. (2011) who find that the trades of insiders in firms with lax insider trading policies predict future earnings news, we focus on CEO's insider trading behavior prior to quarterly earnings announcements. Specifically, we predict that insider trading by out-of-integrity CEOs is related to earnings announcement news while insider trading by high-integrity CEOs is not.

H3: The predictive ability of insider trading on future earnings news is stronger for out-ofintegrity CEOs than for high-integrity CEOs.

In the next section, we describe the sample, data and methodology that we use to test our hypotheses.

\subsection{Data, sample and methodology}

The sample in this study is determined mainly by the overlap between the Thomson-Reuters Insider Trading data feed and the Compact Disclosure database disks available from the Wharton Library at the University of Pennsylvania. Thomson-Reuters collects Securities and Exchange Commission (SEC) Form 4 filings beginning in 1986. SEC Form 4 details the transactions conducted by company executives, directors, and beneficial owners of more than $10 \%$ of the shares outstanding. For the purpose of this study, we collect CEOs' open market purchases and sales and then keep those transactions for which we can estimate CEO integrity.

For the calculation of the integrity score, we use the shareholder letter as well as the Management Discussion and Analysis (MD\&A) section of the annual report from the Compact Disclosure Discs between 1989 and 2006 when the database approached phase-out to discontinuation. Due to additional requirements to calculate the integrity measure and control variables, our final sample includes 1207 unique firms between 1991 and 2002. 


\subsubsection{Measuring CEO integrity}

We follow Dikolli et al. (2013) who construct an empirical proxy for CEO integrity based on CEOs' abnormal use of causation words in the shareholder letter. The shareholder letter is less regulated than other narratives in the annual report such as the MD\&A section and it is typically signed by the CEO (Abrahamson and Amir 1996). This is important since measuring CEO integrity requires text that most likely reflects the CEO's direct influence. In order to capture the excessive amount of explanations captured by causation words that the CEO uses in the shareholder letter, we estimate the following regression model with pooled ordinary least squares (OLS) for firm $\mathrm{j}$ in year $\mathrm{t}$ and use the residual as the measure of CEO integrity:

$S L_{-} C A U S E_{j, t}=\beta_{0}+\beta_{1} * M D A_{C_{C A U S E}, t}+\beta_{2} * S I Z E_{j, t}+\beta_{3} * M T B_{j, t}+\beta_{4} * \operatorname{stdCFO}_{j, t}+$ $\beta_{5} * \operatorname{stdSALES} S_{j, t}+\beta_{6} * O P C Y C_{j, t}+\beta_{7} * N E G E A R N_{j, t}+\beta_{8} * R O A_{j, t}+\beta_{9} *$ FIRMAGE $_{j, t}+$ $\beta_{10} *$ FIRMAGESQ $_{j, t}+\beta_{11} * S L_{W C}, t+Y E A R_{F E}+\operatorname{INDUSTRY} Y_{F E}+\varepsilon_{j, t}$

where SL_CAUSE (MDA_CAUSE) equals the natural logarithm of one plus the number of causation words in the annual shareholder letter (MD\&A section of 10-K filing); SIZE is the natural $\log$ of total assets; MTB is the market value of equity divided by the book value of equity; stdCFO is the standard deviation of cash from operations over the years $t-1$ to $t-5$; stdSALES is the standard deviation of sales over the years $\mathrm{t}-1$ to $\mathrm{t}-5$; OPCYC is the natural $\log$ of the average operating cycle over the years $\mathrm{t}-1$ to $\mathrm{t}-5$; NEGEARN is the proportion of years from $t-1$ to $t-5$ in which income before extraordinary items is negative, ROA is income before extraordinary items, FIRMAGE is the number of years the firm has been listed on Compustat as of the fiscal year end, FIRMAGESQ is the square of FIRMAGE to capture diminishing marginal effects, and SL_WC is the natural logarithm of the number of words in the shareholder letter. The following is a reproduction of Model 2 in Table 5 of Dikolli et al. (2013) and the residual of this regression is used as the proxy for CEO integrity (SL_CAUSE_RES) whereby higher (lower) values of SL_CAUSE_RES imply higher (lower) abnormal causation and hence lower (higher) integrity. We note that equation (1) is estimated using all firm-years for which the shareholder letter, the MD\&A section, and sufficient data to construct control variables are available. The sample underlying equation (1) thus does not condition on an overlap with insider trading data from Thomson Reuters.

As expected, Table 4.1 documents a strong correlation between the number of causation words in the shareholder letter and the MD\&A section of the 10-K. We contend that the annual shareholder letter better captures CEO language usage than the MD\&A because lawyers significantly monitor MD\&A wording (Choudhary et al. 2012). However, if the MD\&A reflects a sufficient portion of CEO language, this specification will work against the residual from equation (1) capturing CEO causation statements and biases against finding results consistent with our hypotheses. 


\subsubsection{Insider trading profitability}

The profitability of insider transactions is difficult to measure since the holding periods of insider transactions can only be imperfectly inferred from SEC filings. ${ }^{27}$ Hence, prior literature has resorted to various approaches to estimate the profitability of insider transactions. We will test Hypothesis 1, using each of the three approaches discussed below.

\subsubsection{Calendar-time regressions}

Eckbo and Smith (1998), Jeng et al. (2003), and Cohen et al. (2012) use calendar-time portfolio regressions to measure insider trading profitability. ${ }^{28}$ Separate portfolios are formed for insider purchases and insider sales and the monthly equally weighted, firm size weighted, or trade size weighted excess returns of these portfolios are then regressed on the monthly returns of benchmark portfolios.

A firm enters a portfolio in the month following the insider transaction and stays in the portfolio for twelve months. Hence, portfolios are rebalanced monthly with firms entering or leaving the portfolio and - in the case of the firm size weighted and trade size weighted portfolios - also based on beginning-of-month firm market value and beginning-of-month market value of the shares traded by the insider, respectively. The intercept of these regressions is interpreted as the average monthly abnormal return to these portfolios which, in turn, is a proxy for insider trading profitability. The regression model takes the following form and is estimated for each insider trading portfolio $\mathrm{p}$ separately.

$R_{p t}-R_{f t}=\alpha_{p}+\beta_{p} * M K T R F_{t}+s_{p} * S M B_{t}+h_{p} * H M L_{t}+u_{p} * U M D_{t}+q_{p} *$ $A Q F A C T O R_{t}+\varepsilon_{p t}$

We follow prior literature and use benchmark returns suggested in Fama and French (1993), Carhart (1997), and Francis et al. (2005): $R_{p}-R_{f}$ is the monthly portfolio return in excess of the risk-free rate; MKTRF is the monthly excess return on the market; SMB is the monthly return on a portfolio which is long in low-market-capitalization stocks and short in high-market-capitalization stocks; HML is the monthly return on a portfolio that is long in high book-to-market stocks and short in low book-to-market stocks; UMD is the monthly return on a portfolio that is long in stocks with the highest returns over the past 12 months and short in stocks with the lowest returns over the past 12 months; and AQFACTOR is the monthly return on a portfolio that is long in stocks with high accrual quality and short in stocks with low accrual quality. We include the latter factor for two reasons. First, prior research suggests that insiders exploit the accrual anomaly (Core et al., 2006) and generate higher insider trading profits when earnings quality is low (Aboody et al., 2005). More importantly, Dikolli et al. (2013) document that out-of-integrity CEOs report lower quality accruals than high-integrity CEOs.

\footnotetext{
${ }^{27}$ See Jeng et al. (2003) for a discussion of this issue.

${ }^{28}$ See Barber and Lyon (1997), Kothari and Warner (1997), Fama (1998), Lyon et al. (1999), Brav (2000), Loughran and Ritter (2000), and Mitchell and Stafford (2000) for a discussion of calendar-time regression techniques and, more generally, long-horizon event studies.
} 


\begin{tabular}{|c|c|}
\hline MDA_CAUSE & $\begin{array}{l}0.279 * * * \\
(0.01)\end{array}$ \\
\hline SIZE & $\begin{array}{l}-0.000 \\
(0.00)\end{array}$ \\
\hline MTB & $\begin{array}{l}-0.000 \\
(0.00)\end{array}$ \\
\hline stdCFO & $\begin{array}{r}0.001 \\
(0.00)\end{array}$ \\
\hline stdSALES & $\begin{array}{l}-0.001 * \\
(0.00)\end{array}$ \\
\hline OPCYC & $\begin{array}{l}0.001 * * * \\
(0.00)\end{array}$ \\
\hline NEGEARN & $\begin{array}{r}0.000 \\
(0.00)\end{array}$ \\
\hline ROA & $\begin{array}{l}-0.003 * * * \\
(0.00)\end{array}$ \\
\hline FIRMAGE & $\begin{array}{l}-0.000 * * * \\
(0.00)\end{array}$ \\
\hline FIRMAGESQ & $\begin{array}{l}0.000^{* * * *} \\
(0.00)\end{array}$ \\
\hline SL_WC & $\begin{array}{l}0.002 * * * \\
(0.00)\end{array}$ \\
\hline Constant & $\begin{array}{r}0.000 \\
(0.00)\end{array}$ \\
\hline Industry Fixed Effects & YES \\
\hline Year Fixed Effects & YES \\
\hline $\mathrm{n}$ & 17,309 \\
\hline $\mathrm{R}^{2}$ & 0.266 \\
\hline
\end{tabular}

\footnotetext{
Standard errors clustered by firm in parentheses. $* * *, * *$, and $*$ denote statistical significance at the $0.01,0.05$, and 0.1 level, respectively (two-tailed). SL_CAUSE (MDA_CAUSE) equals the natural logarithm of one plus the number of causation words in the annual shareholder letter (MD\&A section of 10-K filing); SIZE is the natural log of total assets; MTB is the market value of equity divided by the book value of equity; stdCFO is the standard deviation of cash from operations over the years $t-1$ to $t-5$; stdSALES is the standard deviation of sales over the years $t-1$ to $t-5$; OPCYC is the natural $\log$ of the average operating cycle over the years $t-1$ to $t-5$; NEGEARN is the proportion of years from $\mathrm{t}-1$ to $\mathrm{t}-5$ in which income before extraordinary items is negative, ROA is income before extraordinary items, FIRMAGE is the number of years the firm has been listed on Compustat as of the fiscal year end, FIRMAGESQ is the square of FIRMAGE to capture diminishing marginal effects, and SL_WC is the natural logarithm of the number of words in the shareholder letter.
}

For the purpose of this study, we do not create one insider purchasing portfolio and one insider selling portfolio but, instead, double-sort transactions into portfolios. First, we separate insider purchases from insider sales. Second, we also sort based on CEO integrity. This procedure yields six portfolios: Low integrity purchase, medium integrity purchase, high integrity purchase, low integrity sale, medium integrity sale, and high integrity sale. ${ }^{29} \mathrm{We}$

\footnotetext{
${ }^{29}$ To decrease the influence of outliers, we require at least five firms per portfolio month.
} 
regress the monthly equal-weighted, firm size weighted, and trade size weighted excess return of each of these portfolios $\left(\mathrm{R}_{\mathrm{p}}-\mathrm{R}_{\mathrm{f}}\right)$ on monthly benchmark returns and interpret the intercept (ALPHA) of these regressions as insider trading profitability.

\subsubsection{Annual profitability proxy}

Skaife et al. (2012) incorporate the size of the insider transaction in the estimation of insider trading profits. For each insider purchase (sale), the authors calculate the hypothetical profit realized (forgone) after a twelve month holding period by multiplying the buy-and-hold abnormal return following the twelve months after the insider purchase (sale) by the value of shares purchased (sold). Then, a firm-specific annual measure of insider trading profitability is created by adding the within firm-year sum of realized trading profits from insider purchases to the negative of the within firm-year sum of forgone profits from insider sales. The result is scaled by beginning of year market value.

PROFIT $_{i t}=\frac{\sum_{j=1}^{n} \text { BHARET }_{i t j} * V A L U E_{-} B_{-} O U G H T_{i t j}-B_{H A R E T}{ }_{i t j} * V A L U E_{-} S O L D_{i t j}}{M V_{i t-1}} * 100$

Skaife et al. (2012) use size-adjusted returns over a twelve month holding period to calculate the annual insider trading profitability measure (PROFIT\%). In addition, we tabulate analyses with market-adjusted returns and/or six month holding periods.

Since both this insider trading profitability metric as well as the integrity score are annual variables, we examine the relation between CEO integrity (SL_CAUSE_RES) and PROFIT\% in a pooled OLS regression for firm $\mathrm{j}$ in year $\mathrm{t}$, controlling for variables that prior research has shown to be correlated with insider trading profitability. These are above-median analyst coverage (HIGH COVERAGE), lagged firm size (LN(MARKET CAP)), stock return performance over the past six or twelve months (PAST RETURNS), research and development expenditures scaled by total assets (R\&D), the lagged book-to-market ratio (BTM), mean institutional ownership during the year (INSTITUTIONAL OWNERSHIP), stock return volatility over the prior six months (RETURN VOLATILITY), and a marketbased measure of accrual quality (ELOADING).

PROFIT $_{j t}=\beta_{0}+\beta_{1} * S L_{-} C A U S E_{-} R E S_{j, t}+\beta_{2} * H I G H$ COVERAGE $E_{j, t}+\beta_{3} *$ LN(MARKET CAP $)_{j, t}+\beta_{4} *$ PAST RETURNS $S_{j, t}+\beta_{5} * R \& D_{j t}+\beta_{6} * B T M_{j t}+\beta_{7} *$ INSTITUTIONAL OWNERSHIP $_{j t}+\beta_{8} *$ RETURN VOLATILITY $_{j t}+\beta_{9} *$ ELOADING $_{j, t}+$ $Y E A R_{F E}+\operatorname{INDUSTRY_{FE}}+\varepsilon_{j, t}$

In order to test Hypothesis 2, we add the interaction between SL_CAUSE_RES and HIGH COVERAGE to equation (4).

\subsubsection{Predictive ability for one-month-ahead stock returns}

In a recent study, Cohen et al. (2012) use the predictive ability of insider transactions for onemonth-ahead stock returns as a proxy for insider trading profitability. We follow their approach and estimate the following regression equation pooled for firm $\mathrm{j}$ and month $\mathrm{t}$ 
FUTURE MONTH RETURN $N_{j t}=\beta_{0}+\beta_{1} *$ BUY LOW INTEGRITY I $_{j, t}+\beta_{2} *$

BUY HIGH INTEGRITY ${ }_{j, t}+\beta_{3} *$ SELL LOW INTEGRITY ${ }_{j, t}+\beta_{4} *$

SELL HIGH INTEGRITY $Y_{j t}+\beta_{5} *$ PAST MONTH RETURN $N_{j t}+\beta_{6} *$

PAST YEAR RETURN $N_{j t}+\beta_{7} * \operatorname{LN}(\text { MARKET CAP })_{j t}+\beta_{8} * B T M_{j t}+\varepsilon_{j, t}$

where FUTURE MONTH RETURN is the one month ahead stock return; BUY LOW INTEGRITY (BUY HIGH INTEGRITY) is an indicator variable equal to one if there were any purchases by low integrity (high integrity) CEOs in a given firm in month $t$, and zero otherwise. SELL LOW INTEGRITY (SELL HIGH INTEGRITY) is an indicator variable equal to one if there were any sales by low integrity (high integrity) CEOs on a given firm in month $t$, and zero otherwise. Low (high) integrity refers to the highest (lowest) tercile of SL_CAUSE_RES. PAST MONTH RETURN is the stock return in the prior month; PAST YEAR RETURN is the stock return over the prior twelve months, excluding the prior month. LN(MARKET CAP) is the natural logarithm of lagged market capitalization; BTM is the lagged book to market ratio.

\subsubsection{Predictive ability for future earnings news}

In order to test whether insiders trade on private information about future earnings, we follow Jagolinzer et al. (2011) and examine whether insider trades are related to the market reaction around future earnings announcements. We obtain quarterly earnings announcements from the Compustat quarterly tapes and include in the analysis all earnings announcements with insider trading by the CEO in the year before or the year after the earnings announcement. Then we test whether insider trading during the 90 days prior to the quarterly earnings announcement predicts the market reaction at the earnings announcement by estimating the following regression equation with pooled OLS for firm $\mathrm{j}$ and quarter $\mathrm{t}$

BHAR $_{j, t}=\beta_{0}+\beta_{1} *$ BUY LOW INTEGRITY IN,t $_{j}+\beta_{2} *$ BUY HIGH INTEGRITY I,$t+\beta_{3} *$ SELL LOW INTEGRITY $Y_{j, t}+\beta_{4} *$ SELL HIGH INTEGRITY $Y_{j t}+\beta_{5} *$ LN $(\text { MARKET CAP })_{j t}+$ $\beta_{6} * B T M_{j t}+\varepsilon_{j, t}$

where BHAR is the buy-and-hold abnormal (market-adjusted) return over a three day window that is centered on the quarterly earnings announcement date. BUY LOW INTEGRITY (BUY HIGH INTEGRITY) is an indicator variable equal to one if there were any purchases by low integrity (high integrity) CEOs in a given firm during the 90 days prior to the earnings announcement date, and zero otherwise. SELL LOW INTEGRITY (SELL HIGH INTEGRITY) is an indicator variable equal to one if there were any sales by low integrity (high integrity) CEOs of a given firm during the 90 days prior to the earnings announcement date, and zero otherwise. Low (high) integrity refers to the highest (lowest) quartile of SL_CAUSE_RES. LN(MARKET CAP) is the natural logarithm of lagged market capitalization; BTM is the lagged book to market ratio.

\subsection{Empirical analysis}

In the following we present descriptive statistics on the sample firms and insider transactions, followed by the empirical tests of our three hypotheses. 


\subsubsection{Descriptive statistics}

The descriptive statistics in Table 4.2 show that the integrity measure SL_CAUSE_RES has a mean that is close to zero but not exactly zero. This is because SL_CAUSE_RES is the residual of a regression that was estimated on a sample of all firm-years for which the shareholder letter, the MD\&A section, and control variables are available (cf. Dikolli et al., 2013). The present study sample is only a subsample that is restricted by the availability of CEO insider trading data.

Panel A of Table 4.2 reveals that the median firm has a market capitalization of about $\$ 450$ million and 6 analysts. Median annual CEO insider trading profit (PROFIT\%) amounts to about $0.001 \%$ of firm market value. This is lower than in Skaife et al. (2012) since they measure aggregate insider trading profits across all executives while we, given our focus on CEO integrity, focus only on the profits earned by the CEO. Panel B of Table 4.2 shows that insiders sell more shares than they purchase. This is due to sales of shares that insiders did not purchase on the open market but obtained via restricted stock or stock option grants as a form of compensation.

\subsubsection{Insider trading profitability}

The next three sections present the empirical results for three sets of tests of Hypothesis 1. In addition, section 4.2.2 also presents empirical evidence regarding Hypothesis 2.

\subsubsection{Calendar-time portfolio regressions}

In this section, we separately evaluate the profitability of insider purchase transactions and insider sale transactions by using the calendar-time regression methodology. Table 4.3 shows the results for equal weighted (portfolios 1-3), firm size weighted (4-6), and trade size weighted (7-9) insider purchase portfolios. For each of the three weighting procedures, the 'low integrity' portfolio yields the largest average monthly abnormal return (ALPHA). In the case of the equally weighted portfolio and the firm size weighted portfolio, ALPHA decreases monotonically with the level of integrity. The average monthly abnormal return to the lowintegrity purchases is 111 basis points for the equally weighted portfolio, 128 basis points for the firm size weighted portfolio, and 201 basis points for the trade size weighted portfolio. Across all nine portfolios, the coefficient on the market excess return (MKTRF) falls between 0.85 and 1.18 .

The coefficients on SMB, HML, and UMD reveal that insiders tend to purchase small stocks, value stocks, and stocks that performed poorly in the past which is consistent with prior research (e.g. Rozeff and Zaman, 1998; Jeng et al., 2003; Piotroski and Roulstone, 2005). There is no clear pattern observable for AQFACTOR. Overall, these results support the prediction that insider purchases by out-of-integrity CEOs are more profitable than those of high-integrity CEOs.

Next, we examine insider sale portfolios. We follow exactly the same steps as for the purchase portfolios, except that we form and rebalance the portfolios based on the incidence and value of insider sales rather than insider purchases. Table 4.4 shows the calendar-time portfolio regressions for insider sales. 
Table 4.2. Descriptive Statistics

\begin{tabular}{|c|c|c|c|c|c|}
\hline & Mean & $\begin{array}{r}\text { Standard } \\
\text { Deviation }\end{array}$ & p25 & Median & $\mathrm{p} 75$ \\
\hline \multicolumn{6}{|c|}{ Panel A: Firm-year level } \\
\hline SL_CAUSE_RES & -0.000 & 0.007 & -0.005 & -0.000 & 0.004 \\
\hline LN(MARKET CAP) & 19.916 & 2.032 & 18.527 & 19.880 & 21.252 \\
\hline BTM & 0.564 & 0.538 & 0.247 & 0.427 & 0.720 \\
\hline ANALYSTS & 8.561 & 8.286 & 2.000 & 6.000 & 13.000 \\
\hline HIGHCOVERAGE & 0.498 & 0.500 & 0.000 & 0.000 & 1.000 \\
\hline RETURN VOLATILITY & 0.036 & 0.017 & 0.024 & 0.032 & 0.044 \\
\hline INSTITUTIONAL OWNERSHIP & 49.678 & 24.606 & 31.077 & 53.056 & 69.641 \\
\hline $\mathrm{R} \& \mathrm{D}$ & 0.501 & 0.500 & 0.000 & 1.000 & 1.000 \\
\hline ELOADING & 0.055 & 0.475 & -0.233 & -0.029 & 0.251 \\
\hline PROFIT\% (market-adjusted, 6 months) & 0.012 & 0.211 & -0.007 & 0.001 & 0.018 \\
\hline PROFIT\% (market-adjusted, 12 months) & 0.015 & 0.284 & -0.012 & 0.001 & 0.027 \\
\hline PROFIT\% (size-adjusted, 6 months) & 0.013 & 0.192 & -0.007 & 0.000 & 0.018 \\
\hline PROFIT\% (size-adjusted, 12 months) & 0.013 & 0.259 & -0.014 & 0.001 & 0.024 \\
\hline PAST RETURNS (market-adjusted; 6 months) & 0.078 & 0.468 & -0.210 & 0.015 & 0.268 \\
\hline PAST RETURNS (market-adjusted; 12 months) & 0.149 & 0.767 & -0.353 & -0.010 & 0.437 \\
\hline PAST RETURNS (size-adjusted; 6 months) & 0.073 & 0.456 & -0.199 & 0.017 & 0.250 \\
\hline PAST RETURNS (size-adjusted; 12 months) & 0.143 & 0.743 & -0.326 & 0.007 & 0.398 \\
\hline \multicolumn{6}{|c|}{ Panel B: Trade-level } \\
\hline Insider Purchases & 0.26 & 0.44 & 0.00 & 0.00 & 1.00 \\
\hline Insider Sales & 0.73 & 0.44 & 0.00 & 1.00 & 1.00 \\
\hline Value Purchased & $22,649.75$ & $170,782.06$ & 0.00 & 0.00 & 875.00 \\
\hline Value Sold & $670,681.03$ & $2,261,093.79$ & 0.00 & $54,883.40$ & $344,000.00$ \\
\hline \multicolumn{6}{|c|}{$\begin{array}{l}\text { SL_CAUSE_RES is the integrity proxy developed by Dikolli et al. } 2013 \text { as documented in Table 4.1. LN(MARKET CAP) is } \\
\text { the natural logarithm of market capitalization. BTM is the book-to-market ratio. ANALYSTS is the number of analysts } \\
\text { covering the firm. HIGHCOVERAGE is an indicator variable, which is equal to } 1 \text { for above-median analyst coverage and } \\
\text { equal to } 0 \text { otherwise. RETURN VOLATILITY measures past stock return volatility. INSTITUTIONAL OWNERSHP is the } \\
\text { percentage equity ownership by institutional investors. R\&D is an indicator variable equal to } 1 \text { if the firm reports above-zero } \\
\text { R\&D expenses and equal to } 0 \text { otherwise. ELOADING is the market-based accrual quality measure developed in Ecker, } \\
\text { Francis, Kim, Olsson, Schipper (2006). PROFIT\% is the insider trading profitability measure developed in Skaife, Veenman, } \\
\text { Wangerin (2012). PAST RETURNS is the size-adjusted or market-adjusted stock return measured over the past } 6 \text { or } 12 \\
\text { months. Insider Purchases and Insider Sales are indicator variables equal to } 1 \text { for insider purchases or insider sales, } \\
\text { respectively. Value Purchased (Value Sold) is the } \$ \text { amount of insider purchases (insider sales). }\end{array}$} \\
\hline
\end{tabular}

Table 4.4 documents that while the average monthly abnormal return on the 'low integrity' insider sale portfolio is always negative as expected, none of the nine insider sale portfolios earns abnormal returns. This result is consistent with prior research (e.g. Jeng et al., 2003), which argues that insiders sell for a variety of reasons (other than superior information) such as diversification and liquidity. The coefficient on the excess market return (MKTRF) lies between 0.90 and 1.16 . The evidence, particularly in equally weighted portfolios, also suggests insiders sell more in larger firms. Results on the other asset pricing factors are mixed. These findings suggest that out-of-integrity CEOs' insider sales are not more profitable than the sales of high-integrity CEOs.

Taken together, the results from the calendar-time portfolio regressions show that out-ofintegrity CEOs buy more profitably than high-integrity CEOs do but there is no difference in terms of trading profitability for insider sales. The apparent reluctance of out-of-integrity insiders to sell shares based on private information about adverse future stock price performance may be due to exogenous reasons such as portfolio diversification and/or liquidity needs. However, the reluctance is also consistent with the relatively higher risk of 


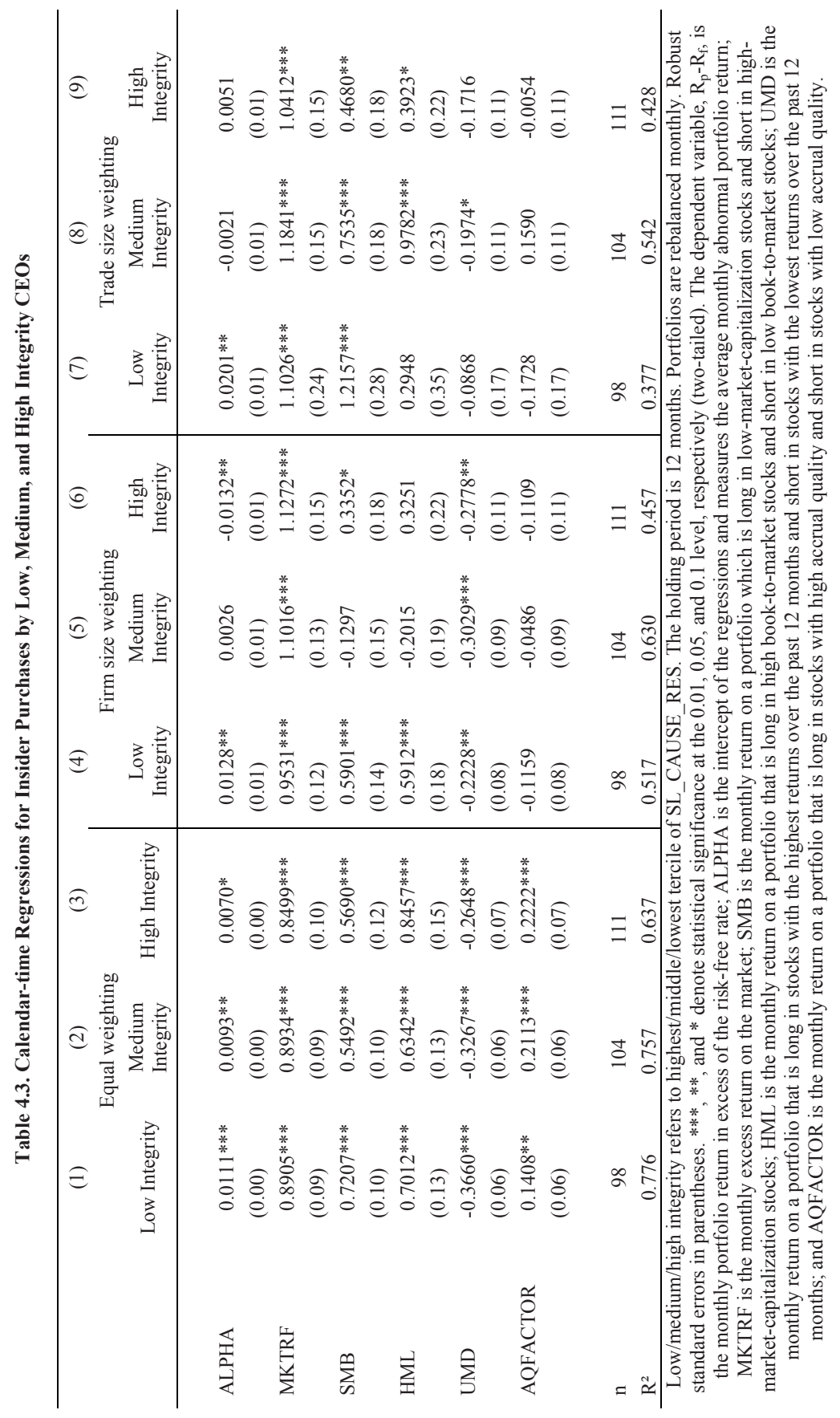




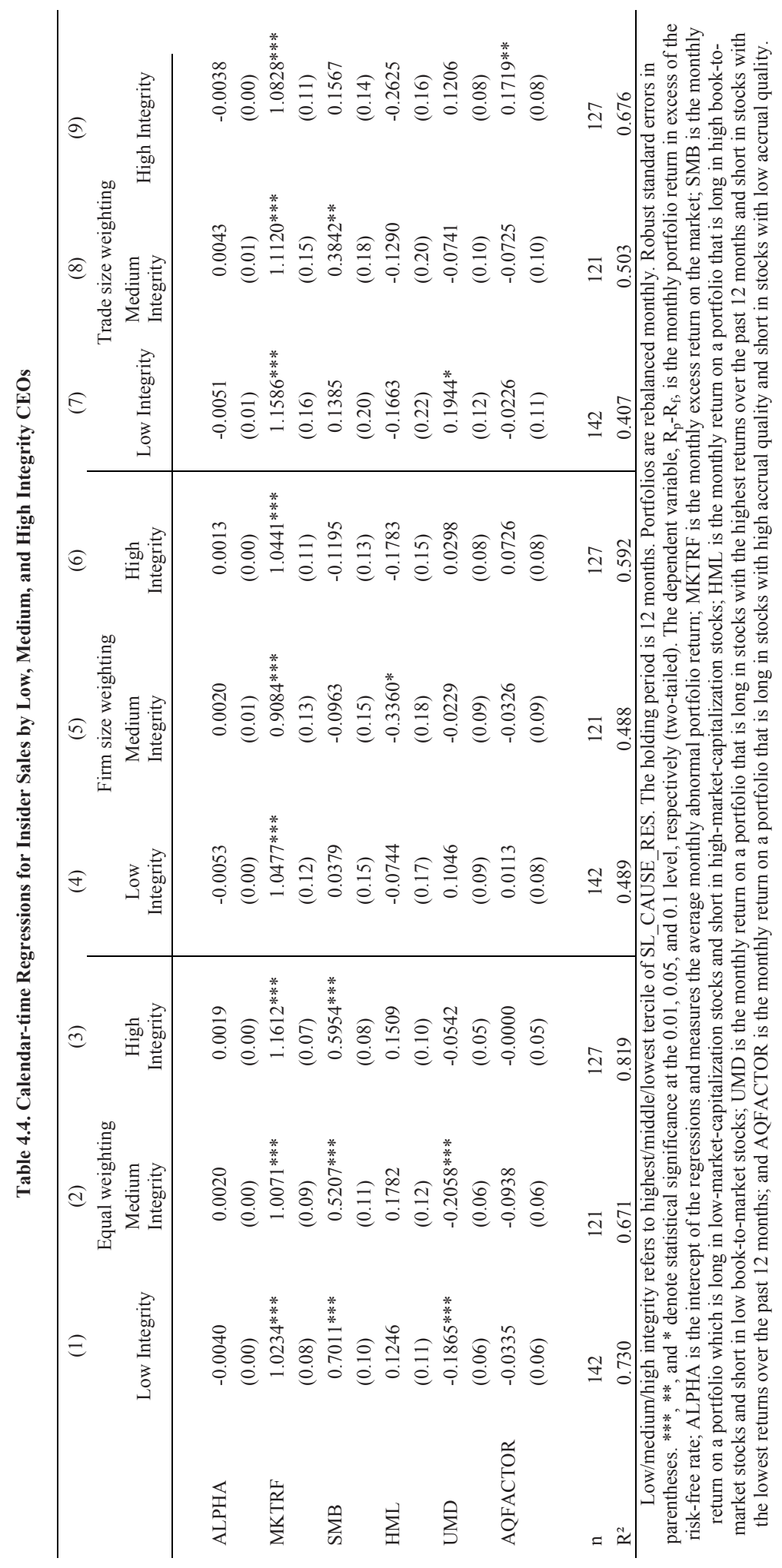




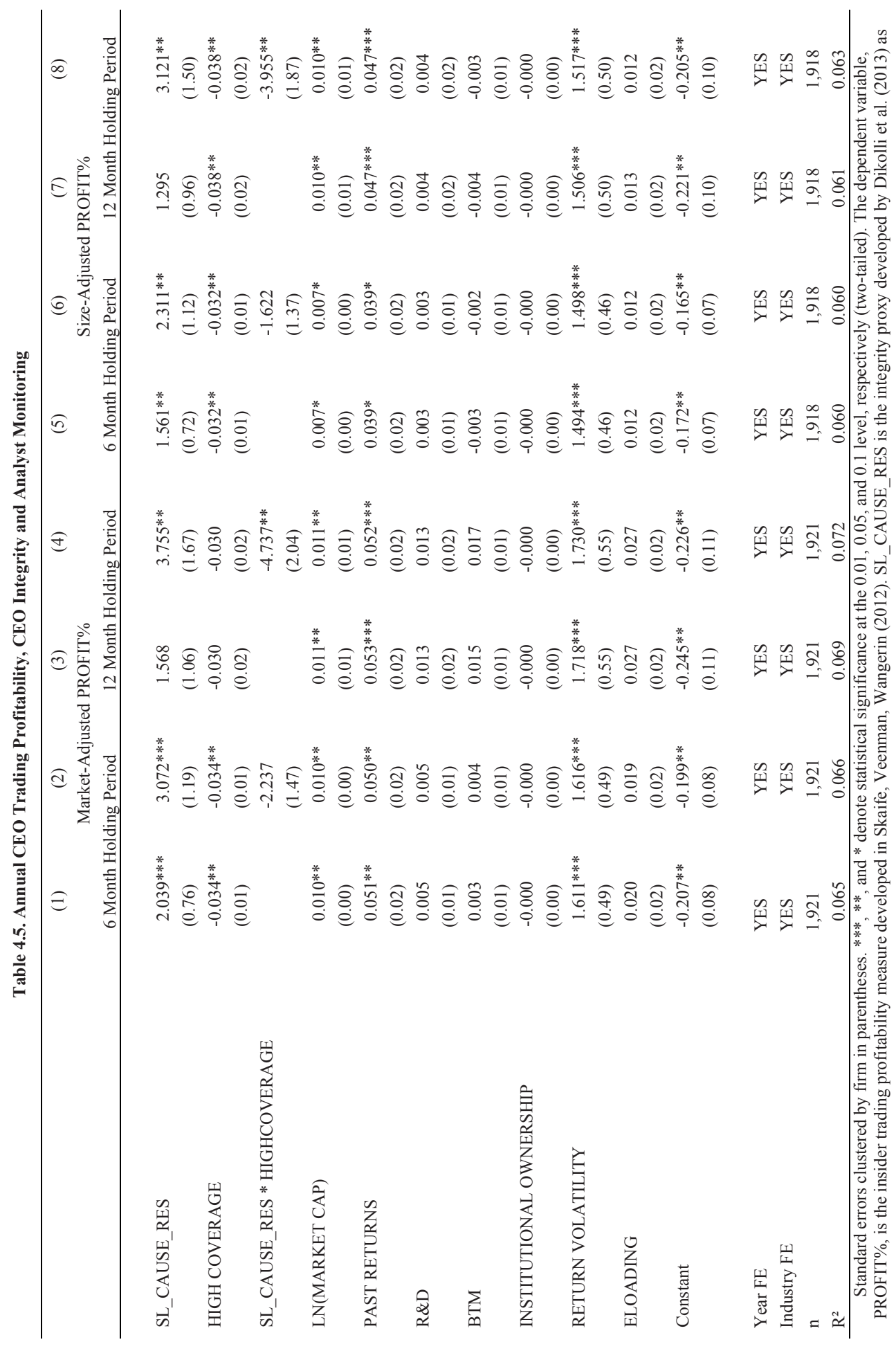




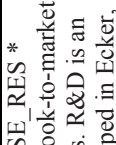

훙 훙

政造

क $\sum$ 㛡

的政

.

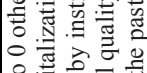

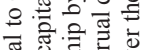

하의

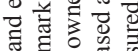

品

求豈

啨品

脶

긍

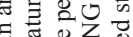

馬

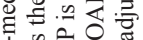

产国

过造.

氜艺家

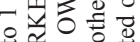

过。

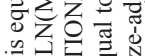

造记

उ

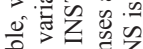

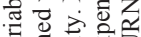

을

당

总 差完

I

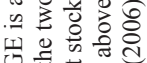

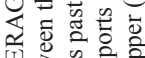

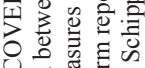

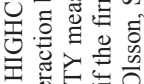

音是通

표

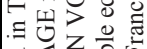

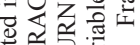

풀

군

过密. 
legal prosecution that is associated with insider selling prior to bad news compared to buying prior to good news.

\subsubsection{Annual profitability proxy}

Next, we employ the annual measure of insider trading profitability developed in Skaife et al. (2012) to test whether out-of-integrity CEOs trade more profitably than high-integrity CEOs (Hypothesis 1) and whether the relation between CEO integrity and trading profits is moderated by analyst monitoring (Hypothesis 2).

The findings are presented in Table 4.5. The coefficient of SL_CAUSE_RES is always positive, indicating that lower integrity leads to higher insider trading profits. The coefficient is also statistically significant in six out of eight model specifications. These results provide support for Hypothesis 1 which predicts that integrity is negatively related to insider trading profitability.

In order to test Hypothesis 2, models 2, 4, 6, and 8 of Table 4.5 include the interaction term SL_CAUSE_RES * HIGHCOVERAGE. As expected, the coefficient on the interaction has a negative sign, indicating that integrity has a weaker (stronger) influence on insider trading profitability in firms with high (low) analyst monitoring. The interaction term is statistically significant in two of the four models. Controlling for the interaction term increases the magnitude and statistical significance of the integrity main effect (SL_CAUSE_RES) across all regression models. The results support Hypothesis 2 and are consistent with the intuition that out-of-integrity CEOs are better able to exploit private information for their personal trading decisions when outside monitoring is low.

The coefficient on the analyst monitoring main effect (HIGH COVERAGE) is always negative and is statistically significant in six out of eight models, implying that the average CEO enjoys lower trading profits in firms with greater monitoring (Frankel and Li, 2004; Huddart and Ke, 2007). In line with Skaife et al. (2012) we show that past stock returns as well as stock return volatility is positively related to insider trading profits.

\subsubsection{Predictive ability for one month ahead stock returns}

Following Cohen et al. (2012) our final test of Hypothesis 1 examines the predictive ability of insider transactions for one month ahead stock returns. If out-of-integrity insiders trade more profitably than high-integrity insiders, we expect the coefficient on BUY LOW INTEGRITY to be significantly positive and the coefficient on SELL LOW INTEGRITY to be significantly negative. In addition, these coefficients must be of greater magnitude than the coefficients on BUY HIGH INTEGRITY and SELL HIGH INTEGRITY.

Table 4.6 reports the results. The coefficient on SELL LOW INTEGRITY is negative and significant at the five percent level or better while the coefficient on BUY LOW INTEGRITY is positive and statistically significant at the one percent level. In contrast, the coefficient on SELL HIGH INTEGRITY is not statistically different from zero and the coefficient on BUY HIGH INTEGRITY is positive and significant but has a lower magnitude and significance level than the coefficient on BUY LOW INTEGRITY. The coefficient on SELL LOW INTEGRITY is significantly more negative than the coefficient on SELL HIGH INTEGRITY (p-value 0.0864) but the coefficients on BUY LOW INTEGRITY and BUY HIGH Integrity are not statistically different (p-value 0.5159 ). These results indicate that out-of-integrity 
CEOs' insider sales are more profitable than those of high-integrity CEOs and, thus, provide corroborating support for Hypothesis 1.

\subsubsection{Predictive ability for future earnings news}

Prior research that examines the question of whether insiders trade on private information provides mixed results (Givoly and Palmon, 1985; Ke et al., 2003; Piotroski and Roulstone, 2005). If insiders do not trade on private information, there is no reason to expect out-ofintegrity CEOs to trade more profitably than high-integrity CEOs. To confirm the prediction that out-of-integrity CEOs generate abnormal trading profits by exploiting private information, we test whether out-of-integrity CEOs' transactions predict future quarterly earnings announcement news. We operationalize the news component of an earnings announcement by the stock market reaction to the announcement, which we then relate to insider trading by out-of-integrity CEOs and high-integrity CEOs during the 90 day period preceding the earnings announcement.

Table 4.6. Predictive Ability of Insider Trades for One Month Ahead Returns

\begin{tabular}{|c|c|c|c|}
\hline & (1) & $\begin{array}{l}\text { Ahead Stocl } \\
(2)\end{array}$ & (3) \\
\hline BUY LOW INTEGRITY & $\begin{array}{l}0.030 * * * \\
(0.01)\end{array}$ & & $\begin{array}{l}0.026^{* * *} \\
(0.01)\end{array}$ \\
\hline BUY HIGH INTEGRITY & $\begin{array}{l}0.022 * * \\
(0.01)\end{array}$ & & $\begin{array}{l}0.018^{*} \\
(0.01)\end{array}$ \\
\hline SELL LOW INTEGRITY & & $\begin{array}{l}-0.023^{* * *} \\
(0.01)\end{array}$ & $\begin{array}{l}-0.016^{* *} \\
(0.01)\end{array}$ \\
\hline SELL HIGH INTEGRITY & & $\begin{array}{l}-0.009 \\
(0.01)\end{array}$ & $\begin{array}{l}-0.002 \\
(0.01)\end{array}$ \\
\hline PAST MONTH RETURN & $\begin{array}{l}-0.040^{*} \\
(0.02)\end{array}$ & $\begin{array}{l}-0.043 * \\
(0.02)\end{array}$ & $\begin{array}{l}-0.037 * \\
(0.02)\end{array}$ \\
\hline PAST YEAR RETURN & $\begin{array}{c}0.001 \\
(0.01)\end{array}$ & $\begin{array}{l}-0.000 \\
(0.01)\end{array}$ & $\begin{array}{c}0.002 \\
(0.01)\end{array}$ \\
\hline LN(MARKET CAP) & $\begin{array}{l}-0.003 * \\
(0.00)\end{array}$ & $\begin{array}{l}-0.004^{* *} \\
(0.00)\end{array}$ & $\begin{array}{l}-0.003 * \\
(0.00)\end{array}$ \\
\hline BTM & $\begin{array}{l}0.014^{*} \\
(0.01)\end{array}$ & $\begin{array}{l}0.014 * \\
(0.01)\end{array}$ & $\begin{array}{l}0.013 * \\
(0.01)\end{array}$ \\
\hline Constant & $\begin{array}{l}0.066^{*} \\
(0.04)\end{array}$ & $\begin{array}{l}0.097^{* * *} \\
(0.04)\end{array}$ & $\begin{array}{l}0.069 * \\
(0.04)\end{array}$ \\
\hline $\begin{array}{l}\mathrm{n} \\
\mathrm{R}^{2}\end{array}$ & $\begin{array}{l}3,348 \\
0.018\end{array}$ & $\begin{array}{l}3,348 \\
0.016\end{array}$ & $\begin{array}{l}3,348 \\
0.019\end{array}$ \\
\hline \multicolumn{4}{|c|}{$\begin{array}{l}\text { Standard errors clustered by firm in parentheses. } * * *, * *, \text { and } * \text { denote statistical significance at the } 0.01,0.05, \text { and } 0.1 \text { level, } \\
\text { respectively (two-tailed). The dependent variable, One Month Ahead Stock Return, is the one month ahead stock return; } \\
\text { BUY LOW INTEGRITY (BUY HIGH INTEGRITY) is an indicator variable equal to one if there were any purchases by low } \\
\text { integrity (high integrity) CEOs in a given firm in month t, and zero otherwise. SELL LOW INTEGRITY (SELL HIGH } \\
\text { INTEGRITY) is an indicator variable equal to one if there were any sales by low integrity (high integrity) CEOs on a given } \\
\text { firm in month t, and zero otherwise. Low (high) integrity refers to the highest (lowest) tercile of SL_CAUSE_RES. PAST } \\
\text { MONTH RETURN is the stock return in the prior month; PAST YEAR RETURN is the stock return over the prior twelve } \\
\text { months, excluding the prior month. LN(MARKET CAP) is the natural logarithm of lagged market capitalization; BTM is the } \\
\text { lagged book to market ratio. }\end{array}$} \\
\hline
\end{tabular}


Table 4.7. Predictive Ability of Insider Trades for Future Earnings Announcement News

\begin{tabular}{|c|c|c|c|}
\hline & \multicolumn{3}{|c|}{ BHAR } \\
\hline & $(1)$ & $(2)$ & (3) \\
\hline \multirow[t]{2}{*}{ BUY LOW INTEGRITY } & $0.014 * *$ & & $0.014 * *$ \\
\hline & $(0.01)$ & & $(0.01)$ \\
\hline \multirow{2}{*}{ BUY HIGH INTEGRITY } & 0.005 & & 0.005 \\
\hline & $(0.01)$ & & $(0.01)$ \\
\hline \multirow[t]{2}{*}{ SELL LOW INTEGRITY } & & $-0.008^{*}$ & $-0.008 *$ \\
\hline & & $(0.00)$ & $(0.00)$ \\
\hline \multirow[t]{2}{*}{ SELL HIGH INTEGRITY } & & -0.001 & -0.001 \\
\hline & & $(0.00)$ & $(0.00)$ \\
\hline \multirow[t]{2}{*}{ LN(MARKET CAP) } & 0.000 & 0.000 & 0.000 \\
\hline & $(0.00)$ & $(0.00)$ & $(0.00)$ \\
\hline \multirow[t]{2}{*}{ BTM } & 0.003 & 0.003 & 0.003 \\
\hline & $(0.00)$ & $(0.00)$ & $(0.00)$ \\
\hline \multirow[t]{2}{*}{ Constant } & 0.001 & 0.002 & 0.000 \\
\hline & $(0.01)$ & $(0.01)$ & $(0.01)$ \\
\hline $\mathrm{n}$ & 13,857 & 13,857 & 13,857 \\
\hline $\mathrm{R}^{2}$ & 0.001 & 0.001 & 0.001 \\
\hline \multicolumn{4}{|c|}{$\begin{array}{l}\text { BHAR refers to the abnormal (market-adjusted) buy-and-hold stock return during a 3-day window centered on the quarterly } \\
\text { earnings announcement. Standard errors clustered by firm in parentheses. } * * *, * * \text {, and * denote statistical significance at the } \\
0.01,0.05 \text {, and } 0.1 \text { level, respectively (two-tailed). The dependent variable, BHAR, is the buy-and-hold abnormal (market- } \\
\text { adjusted) return over a three day window that is centered on the quarterly earnings announcement date. BUY LOW } \\
\text { INTEGRITY (BUY HIGH INTEGRITY) is an indicator variable equal to one if there were any purchases by low integrity } \\
\text { (high integrity) CEOs in a given firm during the } 90 \text { days prior to the earnings announcement date, and zero otherwise. SELL } \\
\text { LOW INTEGRITY (SELL HIGH INTEGRITY) is an indicator variable equal to one if there were any sales by low integrity } \\
\text { (high integrity) CEOs of a given firm during the } 90 \text { days prior to the earnings announcement date, and zero otherwise. High } \\
\text { and low integrity classifications are based on the quartiles of SL_CAUSE_RES. LN(MARKET CAP) is the natural logarithm }\end{array}$} \\
\hline
\end{tabular}

The results of this analysis are presented in Table 4.7. As expected, out-of-integrity CEOs' insider purchases predict a more favorable market reaction around the quarterly earnings announcement while out-of-integrity CEOs' insider sales predict a more unfavorable market reaction. Importantly, the purchases and sales by high-integrity CEOs do not have any predictive power with respect to future earnings news. Although earnings news are not the only piece of private information that insiders might trade on, the results in Table 4.7 confirm the prediction that out-of-integrity CEOs make greater use of private information for their personal trading decisions than high-integrity CEOs, which supports Hypothesis 3.

\subsection{Conclusion}

Insider transactions are widely followed by investors, the SEC, and the business press. Entire websites, sections in business newspapers, and regulatory efforts are dedicated to tracking the "smart money" in an attempt to find cues for investment decisions or to identify litigation targets. However, given the abundance of insider trades that are disclosed every day, it is difficult to filter out those insider transactions which are truly informative.

In this paper, we relate CEO insider trading profitability and the propensity to trade on private information to an empirical measure of CEO integrity that is based on the abnormal use of causation words in the shareholder letter of the annual report. Arguing that out-of- 
integrity insiders are more likely to exploit private information for their personal trading decisions than high-integrity insiders, we predict and find that CEOs' trading profits are a decreasing function of CEO integrity. This result holds across a broad range of proxies for trading profitability and is stronger in firms with lower analyst monitoring. Consistent with the prediction that out-of-integrity CEOs trade on private information, we document that the trades of out-of-integrity CEOs predict quarterly earnings news while the trades of highintegrity CEOs do not.

These results contribute to the insider trading literature by identifying - based on insiders' personal characteristics - which insider trades are most likely based on private information and predictive of future stock market performance. This is important for investors as well as the SEC. Secondly, we contribute to the literature that examines the influence of manager characteristics on firms policies and outcomes (e.g. Bertrand and Schoar, 2003). We identify integrity as an important characteristic that affects CEOs' personal trading decisions and is, hence, likely to be related to other firm events (cf. Dikolli et al., 2013). Lastly, we provide further construct validity for the CEO integrity measure, which opens the door for future research on the economic consequences of CEO integrity. 



\section{Summary and conclusion}

This dissertation examines issues in insider trading that are of interest to academics, investors, regulators and corporate insiders themselves. Regarding the contributions of the results in this dissertation to academics, I document a number of findings that contribute to several streams of the Accounting and Finance literature. First, the results in this dissertation add to the discussion on the variation in insider trading behavior and trading profits (Givoly and Palmon, 1985; Aboody and Lev, 2000; Ke et al., 2003; Roulstone, 2003; Huddart and Ke, 2007; Cohen et al., 2012; Davidson et al., 2013). Specifically, I show that insider trading behavior is influenced by information asymmetry that arises during the patent application process in the US (chapter 2). Next, I find that insider trading behavior is also influenced by macroeconomic conditions that influence the efficiency with which public information is incorporated in share prices (chapter 3). Third, I contribute to this literature by showing that insider characteristics, such as integrity, drive insider trading behavior and profitability (chapter 4).

Relatedly, the findings also contribute to the discussion on whether insiders are able to identify mispricing and change their behavior accordingly. This is important if researchers intend to distinguish between insider transactions that are likely driven by private information, mispricing of public information, or no information at all (the latter is supposedly the case when insiders have strong liquidity or diversification concerns). It is also important in examining whether executives base other decisions on their perception of the efficiency of capital markets. Such decisions include, among others, disclosure (Bergman and Roychowdhury, 2008; Brown et al., 2011; Seybert and Yang, 2012) and capital structure (Baker and Wurgler, 2002).

Third, the findings in this dissertation add to the literature on the influence of personality traits on corporate events, policies, and outcomes in general and on insider trading behavior in particular. A substantial part of this literature demonstrates that executive "fixed effects" matter for investment decisions (Bertrand and Schoar, 2003), disclosure policies (Bamber et al., 2010), tax aggressiveness (Dyreng et al., 2010), and compensation contracts (Graham et al., 2011). The question that remains is what personal characteristics these fixed effects capture. We complement these studies and others that have examined executive overconfidence (Malmendier and Tate, 2005, 2008; Malmendier et al., 2011), frugality (Davidson et al., 2013), or opportunism (Cohen et al., 2012) as potentially important executive traits by showing that CEO integrity influences insider trading behavior.

Regarding the implications for practitioners, it is clear that outside market participants as well as the SEC are very much interested in corporate insider transactions. The anecdotal evidence about insider trading scandals and the market reaction around the disclosure of insider transactions as presented in chapter one of this dissertation support this claim. Both, investors and the SEC analyze insider transactions in order to identify the ones that are relevant for their purposes. While the SEC cares about those transactions that are based on private information, investors care about insider transactions that are predictive of future share price movements, irrespective of whether these trades are driven by private information or mispricing of publicly available information (that is, unless the investor is so sophisticated 
that she has identified the mispricing without the help of the insider transaction). Given the respective tasks or goals of the SEC and outside investors, the findings in this dissertation are relevant to both in their effort to identify informative and potentially illegal insider transactions. The results of the first study imply that investors as well as the SEC should pay close attention to private information that insiders might acquire during the patent application process. The same holds for similar settings such as the Food and Drug Administration (FDA) approval process. The result of the second study imply that investors should screen insider trading behavior - possibly at the aggregate market level - to identify insiders' perceptions about whether their firms or the market as a whole are fairly priced, under-, or overvalues and, thus, whether price corrections are likely to occur in the future. The findings from the third study suggest that both the SEC and investors should differentiate between the trades of highand low-integrity insiders. The results suggest that this classification can be made using publicly available textual information.

The implications for insiders are more difficult to discuss. Two natural implications assuming that someone at the SEC reads this dissertation - are (a) that insiders should stop trading on information that they acquire during the patent application process and (b) that they should be very careful in their trading behavior if they can be identified - in one way or another - to be of low integrity. In that respect, researchers have increasingly made life difficult for insiders. For example Davidson et al. (2013) hired private investigators to acquire information about criminal records and "lavish lifestyles" of US CEOs and related these information to the CEOs' insider trading profits. The good news for insiders is that chapter 3 of this dissertation raises some hope: If buying (selling) shares based on private information is necessary for one reason or another, insiders should do so when sentiment is low (high). That way, insiders can argue that they traded against market-wide mispricing of publicly available information rather than on private information. ${ }^{30}$

The findings and implications discussed above are subject to a number of caveats, some of which I will discuss in the following. First, any study that examines insider trading profitability suffers from data limitations that inhibit precise measurement of insider trading profits. Specifically, it is difficult - and oftentimes impossible - to correctly infer the exact holding period for insider transactions. In addition, assessing insider trading profitability requires benchmarks against which to evaluate the raw returns that insider transactions "earn" in order to determine whether these returns are greater than expected given the underlying securities' risk profiles. Unfortunately, it is not trivial to estimate these expected, or benchmark returns. More specifically, there is little theoretical guidance on what the appropriate risk factors should be. Particularly in the third empirical study of this dissertation, we try to mitigate concerns regarding these issues by using different holding periods and benchmarks to examine insider trading profitability.

Secondly, any study that investigates mispricing, sentiment, or inefficiencies in the stock market is limited by a lack of theoretical models that are general enough to accommodate the various kinds of anomalies that supposedly exist and persist in capital markets (Fama, 1998). In addition, there are alternative - that is other than sentiment-related - rational explanations

\footnotetext{
${ }^{30}$ I would like to thank Erik Peek for this interesting interpretation of the findings in chapter 3. I hope to examine this issue in the future.
} 
for predictability of stock returns such as time-varying risk aversion. Although Baker and Wurgler $(2006,2007)$ go to great lengths to carefully construct their investor sentiment index, alternative explanations for any findings related to sentiment or mispricing in capital markets cannot be ruled out entirely.

Third, measuring CEO integrity with publicly available data is obviously a challenging task. However, the measure developed in Dikolli et al. (2013) is theory-based and validated with survey data which together provides assurance regarding its legitimacy.

Given the scope of the three empirical studies conducted, there are many topics related to insider trading that this dissertation does not speak to. For example, this dissertation is silent on the costs and potential benefits of insider trading for outside market participants or the firm that employs the particular insiders. With respect to the former, Jeng et al. (2003) argue that the cost that the average insider transaction imposes on outsiders, that is, those market participants that trade with insiders, is immaterial. It would be interesting to examine what the costs associated with out-of-integrity CEOs' insider transactions and insider trading scandals are to shareholders. This would be a first step towards establishing the costs of out-ofintegrity behavior. Obviously, this immediately triggers the question why companies hire outof-integrity employees in the first place. Potential answers to this question encompass issues related to adverse selection, potential (short-term) benefits of out-of-integrity behavior, or the intuition that Boards select CEOs based on a variety of personal characteristics. More broadly, it would be worthwhile to examine whether illegal trading by corporate insiders reflects corporate governance failures and is associated with meaningful costs for firms or their board of directors.

Relatedly, there is little evidence on how companies regulate insider trading by their executives and directors to prevent illegal insider trading and insider trading scandals. While Bettis et al. (2000) and Jagolinzer et al. (2011) show that many companies have insider trading policies, it is not clear what drives the adoption and enforcement of these policies. With respect to enforcement, Jagolinzer et al. document that insiders in firms which require General Council approval of insider transactions trade less profitable. However, the requirement of General Council approval is endogenous as is the selection of executives into firms that have stricter insider trading policies. Providing evidence that insider trading policies and other characteristics of firms' governance systems are simultaneously determined, prior research shows that companies and executives trade off the level of compensation and expected insider trading profits suggesting that firms can save compensation expenses (Roulstone, 2003) and provide higher-powered incentives (Bebchuk and Fershtman, 1994) by implementing laxer insider trading policies. Thus, (potentially illegal) insider trading might indeed provide benefits to companies, which are, hence, confronted with the task of trading off the potential legal costs of insider trading scandals against compensation expenses and incentives.

The above discussion suggests that future research should try to better understand how insider trading policies are imbedded in the system of corporate governance mechanisms. This is problematic, however, given that the concept of corporate governance quality is difficult to grasp, let alone to measure. This dissertation makes no such attempt. The task of relating insider trading and insider trading policies to corporate governance is further complicated by diverging world views on whether current corporate governance practices are efficient or not. Assuming that corporate governance is indeed optimal, the observation that not all firms seem 
to have (and enforce) insider trading policies that only allow insider trading in a short time window following earnings announcements suggests that restricting insider trading is not necessarily beneficial to firms. On the other hand, if one holds the view that there is variation in the degree of optimality of corporate governance, one might hypothesize that stricter insider trading policies reflect better corporate governance. For the researcher, the fact that not all firms have implemented homogenous insider trading policies that only allow trading in a short, pre-specified time windows is obviously a good thing. Such restrictive and homogenous insider trading policies would severely limit the questions that researchers could ask (and who would want that?).

This dissertation neither speaks to the trading of "outside" market participants who potentially have access to inside information. It also does not examine corporate insiders "tipping" off outsiders. In view of these two limitations, this dissertation provides a rather narrow view on insider trading. As mentioned in the introduction, there are other market participants who can potentially acquire inside information. Those are auditors, investments bankers, lawyers, and institutional investors such as hedge funds. Many of the insider trading cases that are prosecuted by the SEC involve these groups of market participants rather than corporate insiders. In addition, many of them involve tipping. Hence, a reasonable question seems to be whether corporate insiders have changed their tactics in response to ever tighter SEC regulation: Rather than trading in their own accounts, executives and directors can tip off outsiders, expecting reciprocation or other favors in turn. This behavior is obviously far more difficult to observe by the SEC compared to regular insider transactions by corporate executives who have to file these transactions with the SEC within two business days. The SEC's investigation into Rajat Gupta (former board member of Goldman Sachs) and Raj Rajaratnam (founder of Galleon) acts as an illustrative example. Unfortunately data on tipping or the trades of investment bankers, lawyers, or even hedge funds are difficult to obtain, restricting research efforts in this area. ${ }^{31}$

\footnotetext{
${ }^{31}$ Bodnaruk et al. (2009) is a creative exception.
} 


Aboody, D., and B. Lev, 2000, Information asymmetry, R\&D, and insider gains, The Journal of Finance 55, 2747-2766.

Aboody, David, John Hughes, and Jing Liu, 2005, Earnings quality, insider trading, and cost of capital, Journal of Accounting Research 43, 651-673.

Abreu, D., and M.K. Brunnermeier, 2003, Bubbles and crashes, Econometrica 71, 173-204.

Agrawal, Anup, and Jeffrey F Jaffe, 1995, Does Section 16b deter insider trading by target managers?, Journal of Financial Economics 39, 295-319.

Ahuja, G., R.W. Coff, and P.M. Lee, 2005, Managerial foresight and attempted rent appropriation: insider trading on knowledge of imminent breakthroughs, Strategic Management Journal 26, 791-808.

Ali, A., K.D. Wei, and Y. Zhou, 2011, Insider trading and option grant timing in response to fire sales (and purchases) of stocks by mutual funds, Journal of Accounting Research 49, 595-632.

Angrist, Joshua D, and Jörn-Steffen Pischke, 2008. Mostly harmless econometrics: An empiricist's companion (Princeton University Press).

Baker, M., and J. Wurgler, 2002, Market timing and capital structure, The Journal of Finance 57, 1-32.

Baker, M., and J. Wurgler, 2006, Investor Sentiment and the Cross-Section of Stock Returns, The Journal of Finance 61, 1645-1680.

Baker, M., and J. Wurgler, 2007, Investor sentiment in the stock market, Journal of Economic Perspectives.

Baker, M., and J. Wurgler, 2012, Behavioral Corporate Finance: An Updated Survey, in Handbook of the Economics of Finance: Volume 2 (Elsevier).

Bamber, Linda Smith, John Jiang, and Isabel Yanyan Wang, 2010, What's my style? The influence of top managers on voluntary corporate financial disclosure, The Accounting Review 85, 1131-1162.

Barber, Brad M, and John D Lyon, 1997, Detecting long-run abnormal stock returns: The empirical power and specification of test statistics, Journal of Financial Economics 43, 341-372.

Barth, M.E., R. Kasznik, and M.F. McNichols, 2001, Analyst coverage and intangible assets, Journal of Accounting Research 39, 1-34.

Bartov, E., and P. Mohanram, 2004, Private information, earnings manipulations, and executive stock-option exercises, Accounting Review 889-920.

Bebchuk, L.A., and C. Fershtman, 1994, Insider trading and the managerial choice among risky projects, Journal of Financial and Quantitative Analysis 29, 1-14.

Ben-David, I., and D. Roulstone, 2010, Idiosyncratic risk and corporate transactions, Working paper.

Bergman, N.K., and S. Roychowdhury, 2008, Investor sentiment and corporate disclosure, Journal of Accounting Research 46, 1057-1083.

Bertrand, Marianne, and Antoinette Schoar, 2003, Managing with style: The effect of managers on firm policies, The Quarterly Journal of Economics 118, 1169-1208. 
Bettis, J.C., J.L. Coles, and M.L. Lemmon, 2000, Corporate policies restricting trading by insiders, Journal of Financial Economics 57, 191-220.

Bodnaruk, Andriy, Massimo Massa, and Andrei Simonov, 2009, Investment banks as insiders and the market for corporate control, Review of financial studies 22, 4989-5026.

Brav, Alon, 2000, Inference in Long-Horizon Event Studies: A Bayesian Approach with Application to Initial Public Offerings, The Journal of Finance 55, 1979-2016.

Brochet, F., 2010, Information Content of Insider Trades before and after the Sarbanes-Oxley Act, The Accounting Review 85, 419-446.

Brown, N.C., T.E. Christensen, W.B. Elliott, and R.D. Mergenthaler, 2011, Investor Sentiment and Pro Forma Earnings Disclosures, Journal of Accounting Research 50.

Brunnermeier, M.K., and S. Nagel, 2004, Hedge funds and the technology bubble, The Journal of Finance 59, 2013-2040.

Carhart, M.M., 1997, On persistence in mutual fund performance, Journal of Finance 57-82.

Chatterjee, Arijit, and Donald C Hambrick, 2007, It's all about me: Narcissistic chief executive officers and their effects on company strategy and performance, Administrative Science Quarterly 52, 351-386.

Cheng, S., V. Nagar, and M.V. Rajan, 2007, Insider trades and private information: the special case of delayed-disclosure trades, Review of financial studies 20, 1833-1864.

Cohen, L., C. Malloy, and L. Pomorski, 2012, Decoding inside information, Journal of Finance 67, 1009-1043.

Core, J., and W. Guay, 1999, The use of equity grants to manage optimal equity incentive levels, Journal of Accounting and Economics 28, 151-184.

Core, John E, Wayne R Guay, Scott A Richardson, and Rodrigo S Verdi, 2006, Stock market anomalies: what can we learn from repurchases and insider trading?, Review of Accounting Studies 11, 49-70.

Cornell, B., W. Landsman, and S. Stubben, 2011, Do Institutional Investors and Security Analysts Mitigate the Effects of Investor Sentiment?, Working paper.

Czarnitzki, D., K. Hussinger, and C. Schneider, 2011, "Wacky" patents meet economic indicators, Economics Letters 113, 131-134.

Davidson, Robert, Aiyesha Dey, and Abbie J Smith, 2013, Executives' Legal Records, Lavish Lifestyles and Insider Trading Activities.

DeLong, J.B., A. Shleifer, L.H. Summers, and R.J. Waldmann, 1990, Noise trader risk in financial markets, Journal of Political Economy 98, 703-738.

Dikolli, Shane, William Mayew, and Thomas Steffen, 2013, Honoring one's word: CEO integrity and accruals quality, Duke University working paper.

Dyreng, Scott D, Michelle Hanlon, and Edward L Maydew, 2010, The effects of executives on corporate tax avoidance, The Accounting Review 85, 1163-1189.

Eckbo, B Espen, and David C Smith, 1998, The conditional performance of insider trades, The Journal of Finance 53, 467-498.

Ederer, F., and G. Manso, 2012, Is pay-for-performance detrimental to innovation?, Working paper.

Elliott, John, Dale Morse, and Gordon Richardson, 1984, The association between insider trading and information announcements, The RAND Journal of Economics 521-536.

Erhard, Werner, and Michael Jensen, 2013, Putting integrity into finance: A purely positive approach, Harvard Business School NOM Unit Working Paper 12-01. 
Erhard, Werner, Michael Jensen, and Steve Zaffron, 2013, Integrity: A positive model that incorporates the normative phenomena of morality, ethics and legality, Harvard Business School NOM Working Paper No. 06-11

Fama, E.F., and K.R. French, 1993, Common risk factors in the returns on stocks and bonds, Journal of Financial Economics 33, 3-56.

Fama, Eugene F, 1998, Market efficiency, long-term returns, and behavioral finance, Journal of Financial Economics 49, 283-306.

Fee, C Edward, Charles J Hadlock, and Joshua R Pierce, 2013, Managers with and without Style: Evidence Using Exogenous Variation, Review of Financial Studies 26, 567-601.

Francis, B., I. Hasan, and Z. Sharma, 2011, Incentives and innovation: evidence from CEO compensation contracts, Bank of Finland Research Discussion Paper No. 17/2011

Francis, Jennifer, Ryan LaFond, Per Olsson, and Katherine Schipper, 2005, The market pricing of accruals quality, Journal of Accounting and Economics 39, 295-327.

Frankel, R., and X. Li, 2004, Characteristics of a firm's information environment and the information asymmetry between insiders and outsiders, Journal of Accounting and Economics 37, 229-259.

Gans, J.S., D.H. Hsu, and S. Stern, 2008, The Impact of Uncertain Intellectual Property Rights on the Market for Ideas: Evidence from Patent Grant Delays, Management Science 54, 982-997.

Givoly, Dan, and Dan Palmon, 1985, Insider trading and the exploitation of inside information: Some empirical evidence, Journal of Business 69-87.

Gow, Ian D, Gaizka Ormazabal, and Daniel J Taylor, 2010, Correcting for cross-sectional and time-series dependence in accounting research, The Accounting Review 85, 483-512.

Graham, John R, Si Li, and Jiaping Qiu, 2011, Managerial attributes and executive compensation, Review of Financial Studies 25, 144-168.

Greene, W., 2010, Testing hypotheses about interaction terms in nonlinear models, Economics Letters 107, 291-296.

Hall, B.H., A.B. Jaffe, and M. Trajtenberg, 2001, The NBER patent citation data file: Lessons, insights and methodological tools, NBER Working Paper 8498.

Hall, B.H., A.B. Jaffe, and M. Trajtenberg, 2005, Market value and patent citations, The RAND Journal of Economics 36, 16-38.

Harhoff, D., F. Narin, F.M. Scherer, and K. Vopel, 1999, Citation frequency and the value of patented inventions, Review of Economics and Statistics 81, 511-515.

Hirschey, M., and V.J. Richardson, 2004, Are scientific indicators of patent quality useful to investors?, Journal of Empirical Finance 11, 91-107.

Hribar, Paul, and Phil Quinn, 2013, Managers and Investor Sentiment, Available at SSRN 2240631.

Huddart, S., B. Ke, and C. Shi, 2007, Jeopardy, non-public information, and insider trading around SEC 10-K and 10-Q filings, Journal of Accounting and Economics 43, 3-36.

Huddart, S.J., and B. Ke, 2007, Information Asymmetry and Cross-sectional Variation in Insider Trading, Contemporary Accounting Research 24, 195-232.

IBM, 2010, Capitalizing on Complexity: Insights from the Global Chief Executive Officer Study, IBM Global Business Services, Somers, NY.

Jaffe, A.B., M. Trajtenberg, and P.M. Romer, 2005. Patents, citations, and innovations: A window on the knowledge economy (The MIT Press). 
Jaffe, Jeffrey F, 1974, Special information and insider trading, The Journal of Business 47, 410-428.

Jagolinzer, Alan D, David F Larcker, and Daniel J Taylor, 2011, Corporate governance and the information content of insider trades, Journal of Accounting Research 49, 1249-1274.

Jeng, L.A., A. Metrick, and R. Zeckhauser, 2003, Estimating the returns to insider trading: A performance-evaluation perspective, Review of Economics and Statistics 85, 453-471.

Jensen, Michael C, 2009, Integrity: Without it nothing works, Harvard NOM Research paper nr. 10-042 16-20.

Jenter, D., 2005, Market timing and managerial portfolio decisions, The Journal of Finance 60, 1903-1949.

Jiang, X., and M.A. Zaman, 2010, Aggregate insider trading: Contrarian beliefs or superior information?, Journal of Banking \& Finance 34, 1225-1236.

Johnson, D.K.N., and D. Popp, 2003, Forced out of the closet: the impact of the American Inventors Protection Act on the timing of patent disclosure, The RAND Journal of Economics 34, 96-112.

Ke, B., S. Huddart, and K. Petroni, 2003, What insiders know about future earnings and how they use it: Evidence from insider trades, Journal of Accounting and Economics 35, 315 346.

Kothari, SP, and Jerold B Warner, 1997, Measuring long-horizon security price performance, Journal of Financial Economics 43, 301-339.

La Porta, E., J. Lakonishok, A. Shleifer, and R. Vishny, 1997, Good News for Value Stocks: Further Evidence on Market Efficiency, The Journal of Finance 52, 859-874.

Lakonishok, J., and I. Lee, 2001, Are insider trades informative?, Review of Financial Studies $14,79-11$.

Lee, C., A. Shleifer, and R. Thaler, 1991, Investor sentiment and the closed-end fund puzzle, Journal of Finance 46, 75-109.

Lerner, J., and J. Wulf, 2007, Innovation and incentives: Evidence from corporate R\&D, The Review of Economics and Statistics 98, 634-644.

Lorie, James H, and Victor Niederhoffer, 1968, Predictive and statistical properties of insider trading, $J L \&$ Econ. 11, 35.

Loughran, Tim, and Jay R Ritter, 2000, Uniformly least powerful tests of market efficiency, Journal of Financial Economics 55, 361-389.

Lyon, John D, Brad M Barber, and Chih-Ling Tsai, 1999, Improved methods for tests of longrun abnormal stock returns, The Journal of Finance 54, 165-201.

Malmendier, U., and G. Tate, 2005, CEO overconfidence and corporate investment, The Journal of Finance 60, 2661-2700.

Malmendier, U., and G. Tate, 2008, Who makes acquisitions? CEO overconfidence and the market's reaction, Journal of Financial Economics 89, 20-43.

Malmendier, U., G. Tate, and J. Yan, 2011, Overconfidence and Early-Life Experiences: The Effect of Managerial Traits on Corporate Financial Policies, The Journal of Finance 66, 1687-1733.

Manso, G., 2011, Motivating innovation, The Journal of Finance 66, 1823-1860.

Mitchell, Mark L, and Erik Stafford, 2000, Managerial decisions and long-term stock price performance*, The Journal of Business 73, 287-329. 
Neal, R., and S.M. Wheatley, 1998, Do measures of investor sentiment predict returns?, Journal of Financial and Quantitative Analysis 33, 523-547.

Ofek, E., and D. Yermack, 2000, Taking stock: Equity-based compensation and the evolution of managerial ownership, The Journal of Finance 55, 1367-1384.

Ofek, Eli, and Matthew Richardson, 2003, Dotcom mania: The rise and fall of internet stock prices, The Journal of Finance 58, 1113-1138.

Petersen, M.A., 2009, Estimating standard errors in finance panel data sets: Comparing approaches, Review of Financial Studies 22, 435-480.

Piotroski, J.D., and D.T. Roulstone, 2005, Do insider trades reflect both contrarian beliefs and superior knowledge about future cash flow realizations?, Journal of Accounting and Economics 39, 55-81.

Rogers, Jonathan L, Douglas J Skinner, and Sarah LC Zechman, 2013, The role of the media in disseminating insider trading news, Fama-Miller working paper.

Roulstone, D.T., 2003, The Relation Between Insider-Trading Restrictions and Executive Compensation, Journal of Accounting Research 41, 525-551.

Rozeff, M.S., and M.A. Zaman, 1998, Overreaction and insider trading: Evidence from growth and value portfolios, The Journal of Finance 53, 701-716.

Seybert, N., and H.I. Yang, 2012, The Party's Over: The Role of Earnings Guidance in Resolving Sentiment-Driven Overvaluation, Management Science 58, 308-319.

Seyhun, H Nejat, 1990, Overreaction or fundamentals: Some lessons from insiders' response to the market crash of 1987, The Journal of Finance 45, 1363-1388.

Seyhun, H Nejat, and Michael Bradley, 1997, Corporate Bankruptcy and Insider Trading*, The Journal of Business 70, 189-216.

Seyhun, H.N., 1986, Insiders' profits, costs of trading, and market efficiency, Journal of Financial Economics 16, 189-212.

Seyhun, H.N., 1992, Why does aggregate insider trading predict future stock returns?, The Quarterly Journal of Economics 107, 1303-1331.

Shefrin, H., 2008, Risk and return in behavioral SDF-based asset pricing models, Journal of Investment Management 6, 4-22.

Skaife, Hollis A, David Veenman, and Daniel Wangerin, 2012, Internal control over financial reporting and managerial rent extraction: Evidence from the profitability of insider trading, Journal of Accounting and Economics.

Smith, C.W., and R.L. Watts, 1992, The investment opportunity set and corporate financing, dividend, and compensation policies, Journal of Financial Economics 32, 263-292.

USPTO, 1999, American Inventors' Protection Act.

USPTO, 2011, General Information Concerning Patents.

Veenman, D., 2013, Do Managers Trade on Public or Private Information? Evidence from Fundamental Valuations, European Accounting Review 22, 427-465. 

Thomas Keusch was born on November $4^{\text {th }}, 1985$ in Aachen, Germany. From 2005 to 2009 he studied business administration, with specializations in Accounting and Corporate Finance at Maastricht University and EDHEC Business School. In September 2009, he joined the PhD program in Accounting at Maastricht University. Thomas conducted part of his dissertation research as a visiting student at Duke University and the University of Pennsylvania. His work has been published in the European Accounting Review and presented at the Management Accounting Section meeting in New Orleans, the Allied Social Science Associations meeting in Philadelphia, and the European Accounting Association meeting in Tallinn. Since April 2014, he works for the Erasmus School of Economics. Thomas is also a fellow with the Harvard Law School Program on Corporate Governance. 
